DANMARKS GEOLOGISKE UNDERSOGELSE

1. R.AEKKE NR. 25

Geological Survey of Denmark I. Series No. 25

\title{
Geology of the Faeroe Islands
}

(Pre-Quateriary)

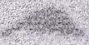

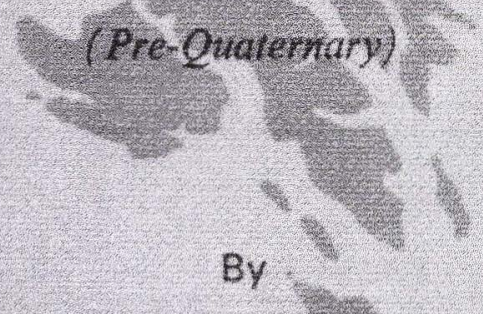

Jóannes Rasmussen and Arne Noe-Nygaard

낭

8.

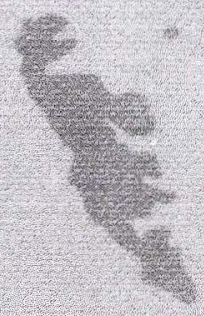

COPENHAGEN 1970 
Geology of the Faeroe Islands 
DANMARKS GEOLOGISKE UNDERSØGELSE

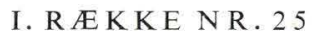

Geological Survey of Denmark I. Series No. 25

\title{
Geology of the Faeroe Islands
}

$$
\text { (Pre-Quaternary) }
$$

\author{
By
}

Jóannes Rasmussen and Arne Noe-Nygaard

\author{
Translated by \\ Gilroy Henderson
}

I kommission hos

C. A. REITZELS FORLAG

Kø B ENHAVN 1970 
8742106095

Andelsbogtrykkeriet i Odense 


\section{Contents}

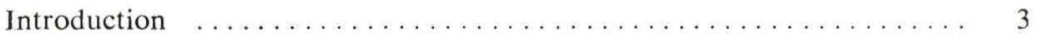

The Faeroe Islands . . . . . . . . . . . . . . . . . . 4

The North Atlantic basalt province .................. 4

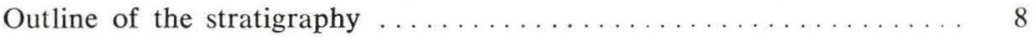

The stratigraphic division $\ldots \ldots \ldots \ldots \ldots \ldots \ldots \ldots \ldots \ldots \ldots$

Marker horizons .......................... 10

The ideal profile (main profile) $\ldots \ldots \ldots \ldots \ldots \ldots \ldots \ldots \ldots \ldots \ldots$

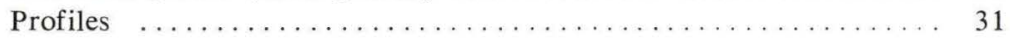

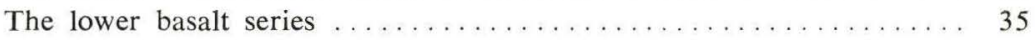

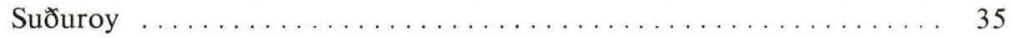

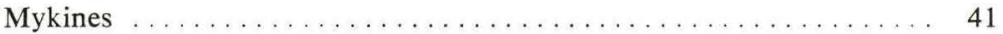

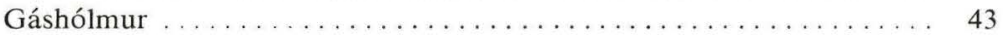

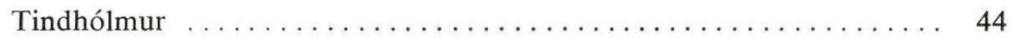

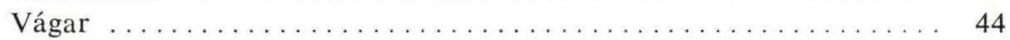

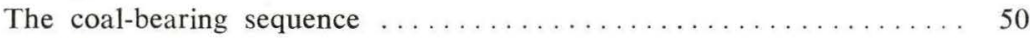

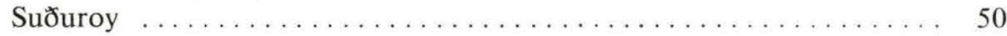

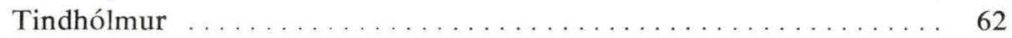

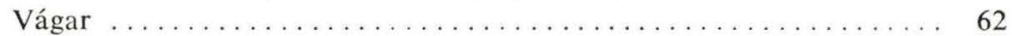

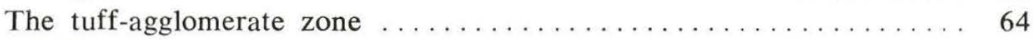

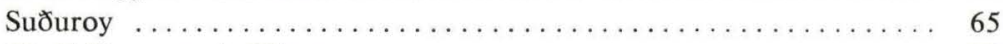

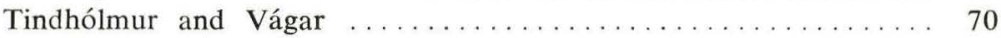

The middle basalt series .......................... 74

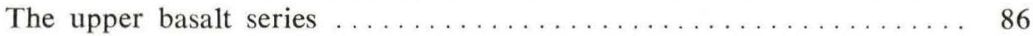

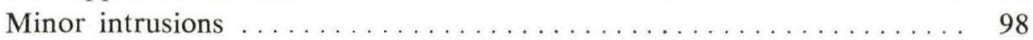

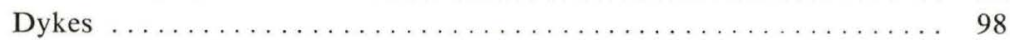

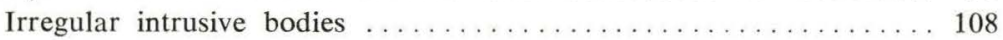

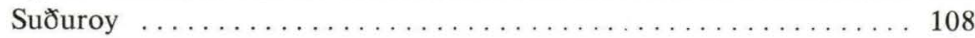

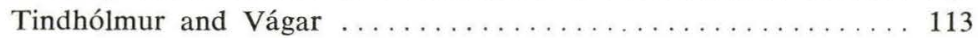

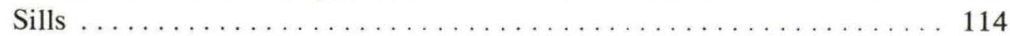

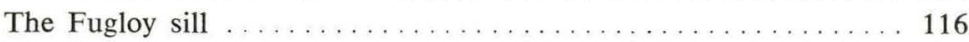

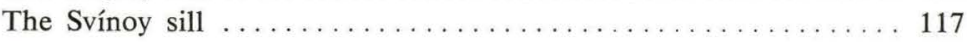

The large Eysturoy sill. . . . . . . . . . . . . . . . . . . 119

The large Streymoy sill . . . . . . . . . . . . . . . . 121

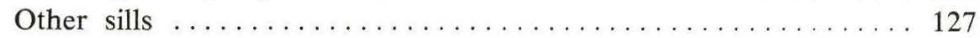

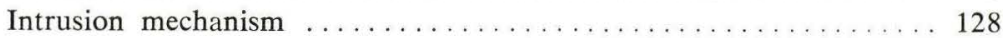

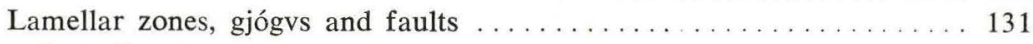

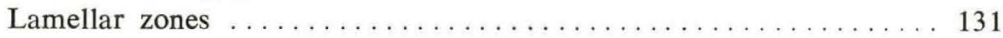

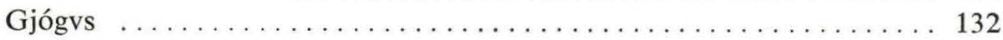

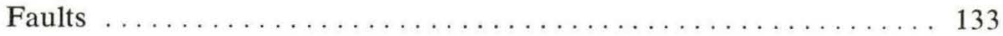




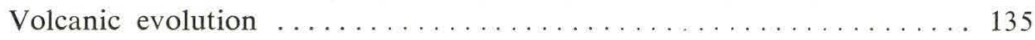

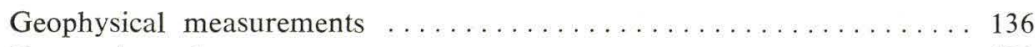

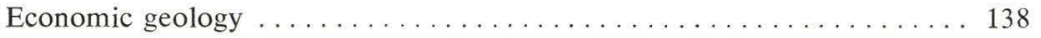

References ................................ 140

Profiles through the coal-bearing sequence $\ldots \ldots \ldots \ldots \ldots$ Plate 1

Successive profiles through the Faroe Islands ........... Plate 2

Geological map of the Faroe Islands, scale 1:200,000 


\section{Introduction}

The present book is designed as an introduction to the geology of the Faeroe Islands and as an aid to the understanding of the geological map of the Faeroe Islands, which was recently published with an accompanying description in Danish by the Geological Survey of Denmark (Danmarks Geologiske Undersøgelse 1. Række Nr. 24. Beskrivelse til Geologisk Kort over Færøerne i målestok 1:50,000 ved Jóannes Rasmussen og Arne Noe-Nygaard. English Summary). The Danish account will be referred to hereafter as the Memoir.

During the geological investigation of the Faeroe Islands it was attempted to produce a map showing a naturally delimited part of the North Atlantic basalt province at a scale larger than that normally used in an area of plateau basalts. This was possible because the area concerned was small and the rocks were well exposed.

One of the main objects of the work was to represent on the map a valid stratigraphic division of the Faeroese sequence. This division was achieved with the aid of marker horizons. By using these it was possible to combine individual profiles to give a continuous main profile through the entire sequence and to correlate a large number of auxiliary profiles to produce areal coverage of lateral variations in lava type at one and the same stratigraphic level. Details of the individual profiles may be found in the Memoir (pp. 75-80, 91-113).

Marker horizons are shown on the geological map, where they are accompanied by a spot height. To facilitate future field work tables are given in the following account (p. 20) (and in the Danish account on pp. 38-70, where they contain more details), listing and describing the various localities where the main marker horizons may be seen, with reference to the topographic maps at $1: 20,000$.

Dykes are shown on the map with a number. This number also refers to the Memoir, where all the assembled data on the dykes have been compiled in tabular form for ease of understanding (see pp. 253-293). In addition, where a dyke is mentioned in the text, 
reference is made to a corresponding dyke number on the map. The letters in front of the number are the first letters in the name of the island where the dyke occurs.

A comprehensive review of the geological literature dealing with the Faeroe Islands up to 1946 can be found in Meddelelser fra Dansk Geologisk Forening (Rasmussen 1946), and an up-to-date bibliography covering work undertaken between 1946 and 1968 is given in the Memoir (pp. 14-16).

\section{The Faeroe Islands}

The Faeroe Islands are a group of islands in the North Atlantic situated between $61^{\circ} 20^{\prime} \mathrm{N}$ and $62^{\circ} 24^{\prime} \mathrm{N}$ and between $6^{\circ} 15^{\prime} \mathrm{W}$ and $7^{\circ} 41^{\prime} \mathrm{W}$. From north to south they extend over a distance of about $118 \mathrm{~km}$, and from east to west over a distance of about $75 \mathrm{~km}$. The total land area is $1399 \mathrm{~km}^{2}$.

The Faeroe Islands comprise 18 larger and smaller islands, as well as a large number of needles, islets and skerries. The islands have an elongated form with a pronounced NW-SE trend, i.e. the same trend as the Wyville-Thompson Ridge; the average height is about $300 \mathrm{~m}$ (the highest point is Slættaratindur, $882 \mathrm{~m}$ ). Towards the south and east the land slopes gently down towards the coast, but towards the west and north the coasts are steep, and are sometimes vertical up to a height of over $700 \mathrm{~m}$. Below sea level there is an abrupt fall for the first $50 \mathrm{~m}$ after which the sea floor slopes regularly down to a depth of $200 \mathrm{~m}$; thereafter there is a rapid descent to the oceanic depths towards the north-east and southwest.

The Faeroe Islands belong geologically to the North Atlantic basalt province.

The North Atlantic basalt province

(the Brito-Arctic basalt province)

It has been clear to two or three generations of geologists that there was an area of plateau basalts, or rather that there were parts of such an area, in the North Atlantic. It has long been considered that these parts, which are now separated from each other by the sea, represented remnants of a formerly existing land mass of 


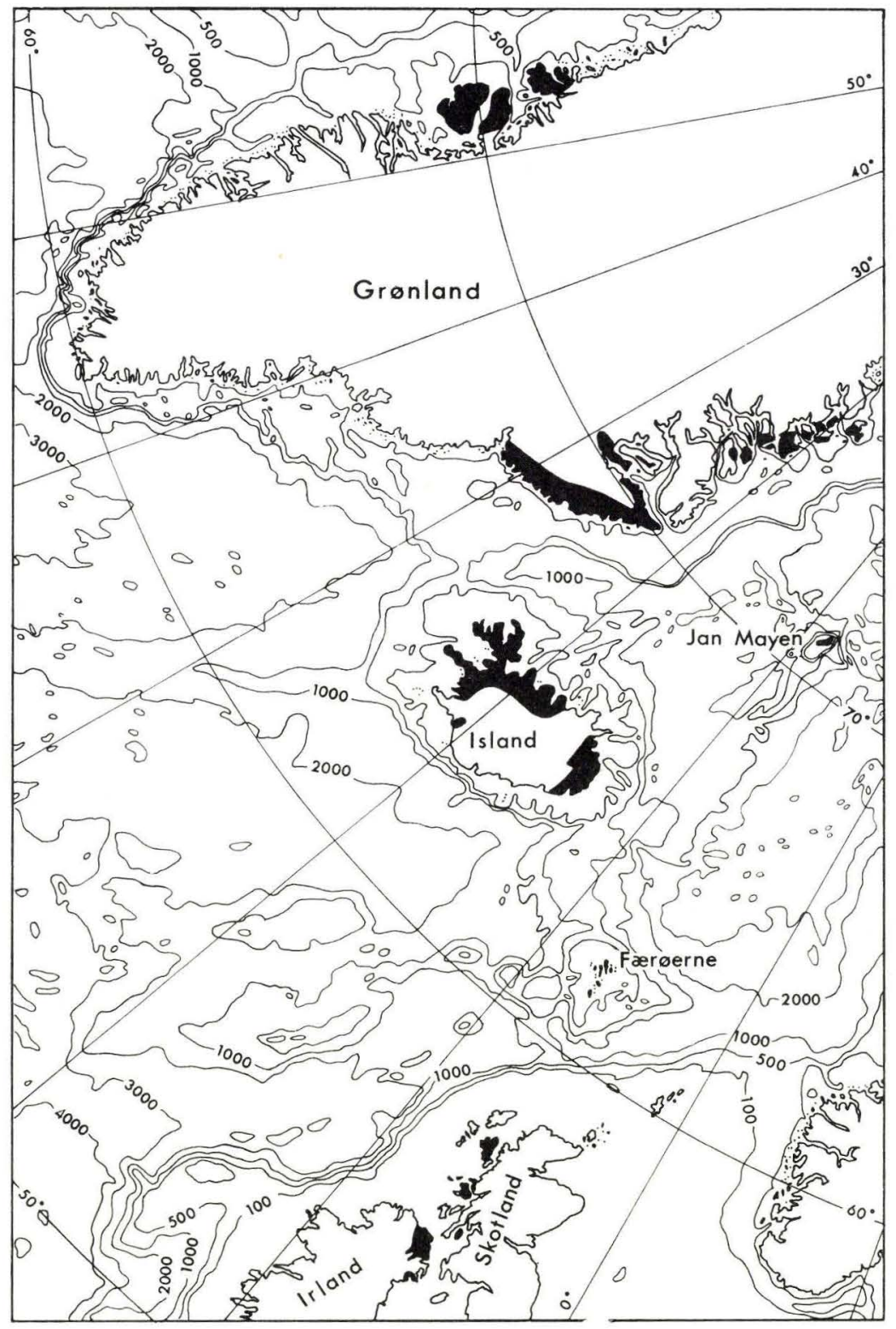

Fig. 1. The North Atlantic basalt province. (Depths in m.) 
volcanic origin, and that most of this land mass had afterwards been submerged below the sea.

The most south-easterly indication of a geologically young basaltic volcanism is to be found in the form of a number of small remnants of volcanoes along the Fennoscandian Border Zone in Scania, and in the form of layers of volcanic ash in the so-called Mo-ler in the Eocene in Denmark (Bøggild 1918), which may have come from volcanism in the Norwegian Deep in the Skagerrak. (See, for example, Noe-Nygaard 1967.)

Plateau basalts proper occur in Northern Ireland (Antrim); remnants of volcanoes and plutonic centres of the same age occur especially along the west coast of Scotland and in the islands of the coast. If we go from here towards the north-west, we encounter the Faeroe Islands and Iceland, and farther still East and West Greenland, with an offshoot of the province in Baffin Island. If we go from Iceland towards the north we meet Jan Mayen, and if we finally go north-east, we arrive at Spitzbergen. These areas are wholly or partly characterized by basaltic volcanism, in particular the Faeroe Islands and Iceland.

We know that the basaltic volcanism in West Greenland started in the Danian, continued through the remainder of the Palaeocene, and was particularly active in the Eocene; in Iceland the new age determinations indicate that the volcanic activity commenced considerably later, viz. in the Miocene. In Spitzbergen volcanic activity is known already from the Jurassic, but volcanic activity continued until after the Ice Age. Both Jan Mayen and Iceland are, as is known, currently subject to volcanic activity.

The age of the volcanic activity in the Faeroe Islands can probably be taken as being older Tertiary (Palaeocene-Eocene), on the basis of palaeobotanical evidence (Rasmussen and Koch 1963; Laufeld 1965). Radioactive age determinations (K/Ar) undertaken by the Geochron Laboratories, Cambridge, Massachusetts (Rasmussen and Noe-Nygaard 1966), give too old an age, judging by later determinations. The latest figures show 50-60 m.y. (Tarling and Gale 1968).

As to the origin of the Faeroe Islands, we have come to the conclusion that the islands form a high-lying part of the WyvilleThompson Ridge, which is an elongated shallow-water feature trending SE-NW across the North Atlantic, probably mainly built up through fissure eruptions. It is likely that locally and at various 
periods there were land areas in the form of islands, perhaps in the form of rows of islands as in the Hawaiian Islands, which nowadays stand up as the highest parts of a submarine volcanic ridge in the northern Pacific Ocean, also built up above a NW-SE trending system of fractures. However, this does not necessarily mean that such islands or groups of islands existed at the same time.

If one looks at the sea charts there is one prominent feature: the SE-NW trend of the Wyville-Thompson Ridge is reflected in the trend of the Faeroese fjord system and in the trend of the drowned fjords off south-east Iceland. This structural feature has had, as will be shown later, a pronounced influence on the course of events in the Faeroe Islands.

Judging from gravity measurements and bottom samples the Wyville-Thompson Ridge is composed of basalt, as are the Faeroe Bank and the Rockall and Porcupine Banks west of Scotland.

If these now-separated areas of plateau basalt, which altogether cover about $250,000 \mathrm{~km}^{2}$, were once part of one land mass, this must have had an area of $2-3$ mill. $\mathrm{km}^{2}$. 


\section{Outline of the stratigraphy}

\section{The stratigraphic division}

Whereas the first accounts of the geology of the Faeroe Islands are purely descriptive and cannot be said to have had any real importance for subsequent geological research, Forchhammer (1824) attempts to make a stratigraphic division of the Faeroese lava sequence on a petrographic basis.

During the present mapping work it was also attempted at first to use purely petrographic criteria as a basis for mapping, but it quickly became clear that this would be difficult to carry out in detail. The following mapping problems were encountered in particular: 1. lateral variations in the same lava flow caused by sinking of heavier mineral grains, 2 . the frequently large number of very thin lava flows with varying composition, which follow one upon the other and 3. the rather frequent thinning-out and overlapping of flows - a characteristic feature of the plateau basalts.

Instead, we have therefore tried during the mapping to express the geological development during the building-up of the islands, and to represent on the maps the boundaries of the various stages of the volcanism. In this way it has been possible to achieve a stratigraphic division, as shown in the purely schematic section through the entire lava sequence. (Fig. 2.)

The lower basalt series. Volcanism commenced with rhythmic activity in the form of fissure eruptions, whereby a series of thick lava flows totalling about $900 \mathrm{~m}$ was formed. The volcanism was interrupted by periods of quiescence, during which interbasaltic tuff-clay sediments were deposited.

The coal-bearing sequence. A long pause in the volcanic activity is represented by a coal-bearing shale sequence up to $15 \mathrm{~m}$ thick.

The tuff-agglomerate zone. The renewed volcanic activity started with a strongly explosive phase, almost without lava production. 


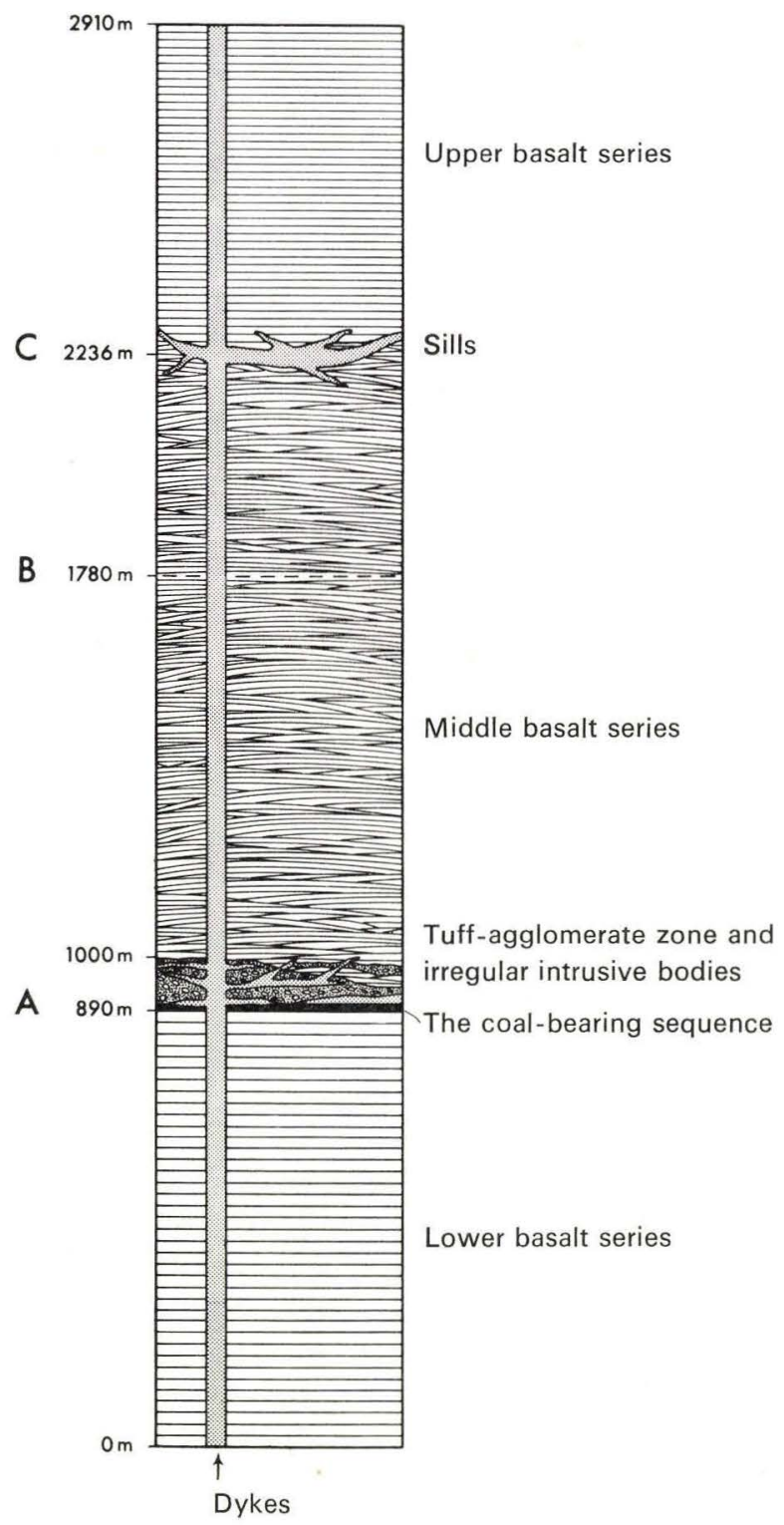

Fig. 2. Schematic section through the lava sequence of the Faeroe Islands. 
Large quantities of pyroclastic material were accumulated along and in the vicinity of the sites of the eruptions.

The middle basalt series. The volcanism proceeded immediately after with a continuous lava production from numerous smaller eruptive sites along the NW-SE trending fjord system, to start with in the form of thin flows, the flows becoming somewhat thicker upwards in the series. The individual lava flows are usually separated by vesicular and scoriaceous zones. Tuff beds are of minor importance, but become more frequent upwards in the series, whose total thickness amounts to about $1,350 \mathrm{~m}$.

The upper basalt series. After a break in the volcanism, which is marked by a minor unconformity and by a large content of pyroclastic material and fragments of basalt from lower levels in the lowest lava flows of this series, a new phase of volcanic activity began, during which the upper basalt series, which has a total thickness of about $675 \mathrm{~m}$, was deposited. We find here the same rhythmic activity as in the lower basalt series. However, the flows very seldom attain the same thickness as those in the lower basalt series. As in the lower basalt series the flows alternate with tuff-clay sediments; these often contain imprints of indeterminable plant remains.

Intrusive rocks are present in the form of dykes, irregular intrusive bodies and sills. Broadly speaking, these all belong to the same eruptive phase. The dykes cut the entire lava sequence; the irregular intrusive bodies are intruded into the coal-bearing beds and the tuff-agglomerate zone, where they locally constitute an important part; all the larger sills lie in the boundary area between the middle and the upper basalt series.

\section{Marker horizons}

In order to be able to make a reliable correlation of various whole or partial profiles and to be able to combine these to produce an ideal profile though the entire lava sequence it has been necessary to establish marker horizons. These have served as fixed levels for linking up profiles measured at random at various localities on the 


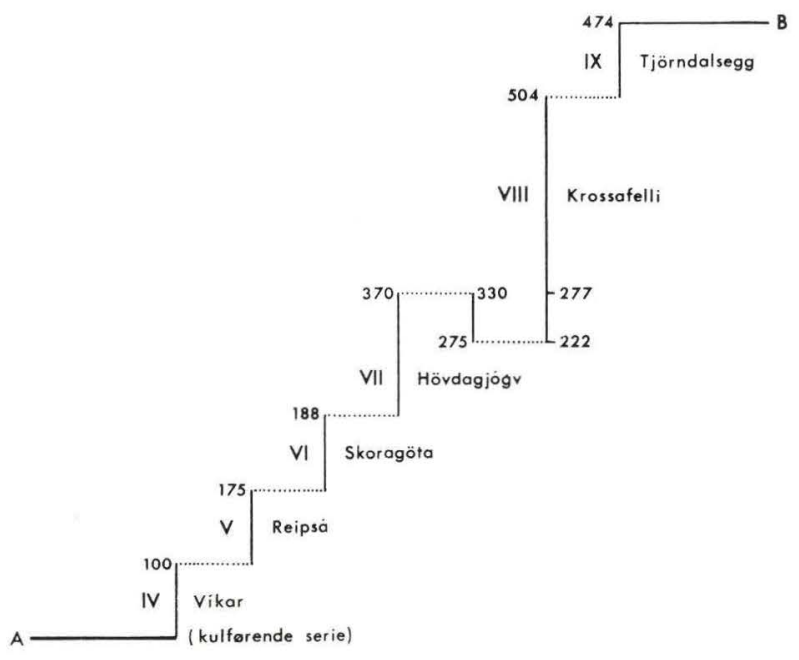

Fig. 3. The Vága section (IV to IX of the main profile).

different islands that happened to be suitable for measuring profiles.

The following stratigraphic boundaries were used to provide marker horizons: lower basalt series - coal-bearing sequence, the A-horizon, (Suðuroy, Tindhólmur, Vágar) and the boundary middle basalt series - upper basalt series, the C-horizon, (Ll. Dímun, St. Dímun, Skúvoy, Sandoy, Hestur, Koltur, Streymoy, Eysturoy, Kallsoy, Kunoy, Borðoy, Viðoy). In addition, a horizon within the middle basalt series, the B-horizon, (Vágar, Streymoy, Eysturoy), which was selected for the purpose and has been drawn on the map, was used as a marker horizon. Where it was desirable, but impossible, to obtain a more complete profile at the same locality and along the same profile line, it was necessary to displace the partial profiles along similar, auxiliary marker horizons (e.g. the Vágar profiles IV-IX and the Sandoy profiles 31-35), which are shown on the map; in this way the individual partial profiles constitute a laterally displaced, but chronologically correct, complete profile. (See fig. 3.)

For practical use, such as for calculating strike and dip, and to enable a check to be kept on the sequence as a whole, "geological" spot heights have been drawn at suitable intervals on the map. 


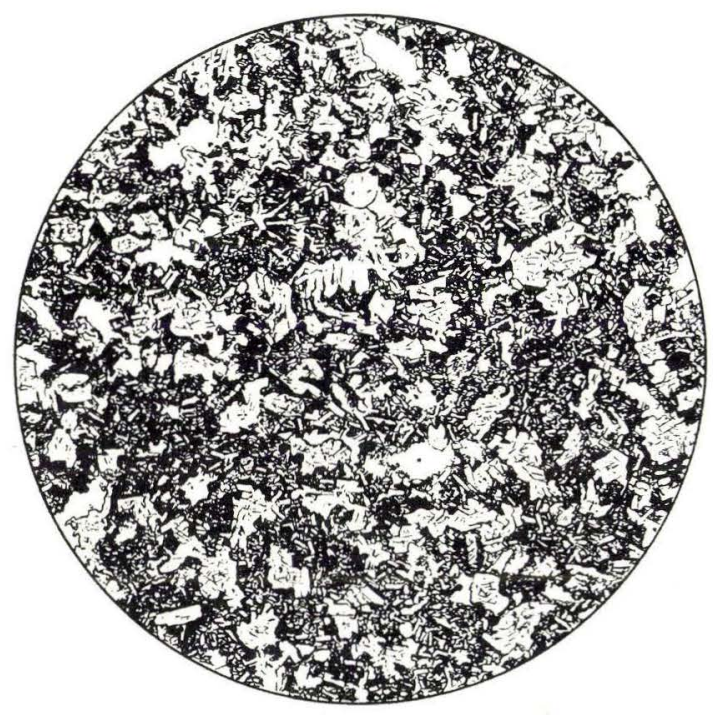

Fig. 4 a. Aphyric basalt, lower basalt series. $\times 15$.

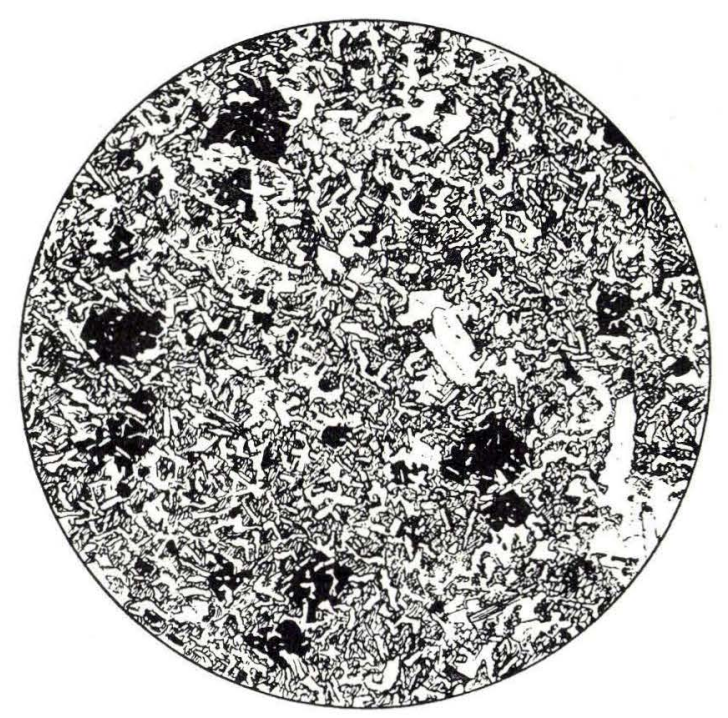

Fig. 4 b. Basalt which is aphyric to the naked eye, but which in thin section is seen to contain semiphenocrysts of black ore with irregular boundaries (black) and a few semiphenocrysts of plagioclase (white, right of centre). Lower basalt series. $\times 15$. 


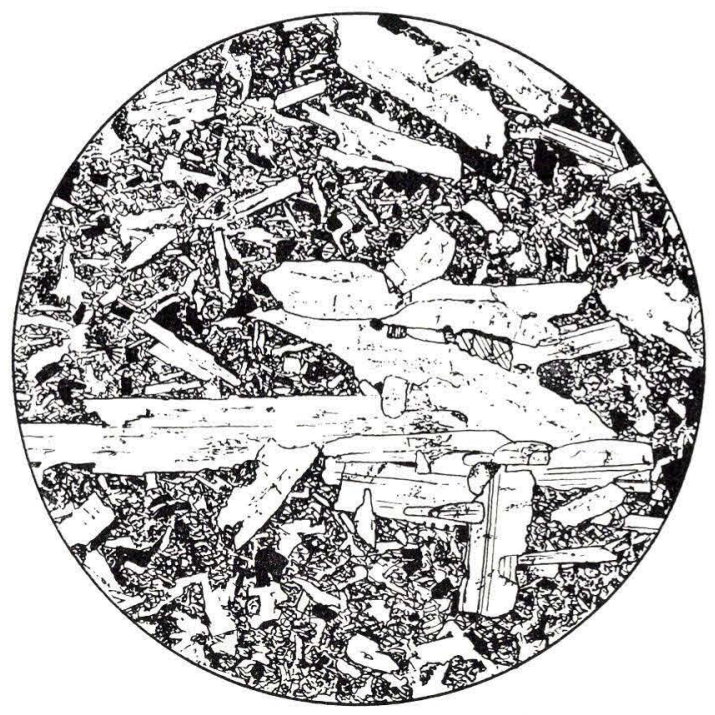

Fig. 4 c. Porphyritic basalt with a group af plagioclase phenocrysis. Middle basalt series. $\times 14$.

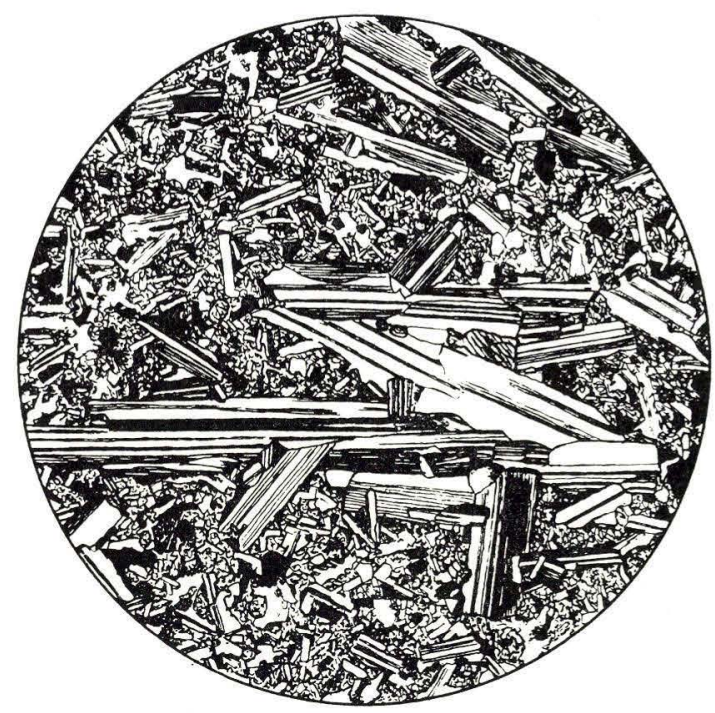

Fig. 4 d. Same section with crossed nicols. $\times 14$. 


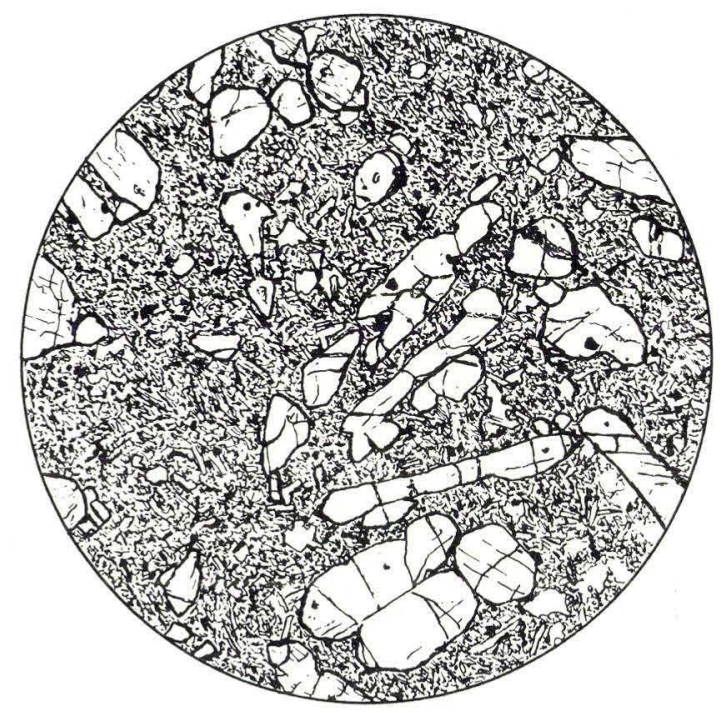

Fig. 4 e. Olivine tholeiitic basalt with rod-shaped phenocrysts of olivine. From the mixed sequence at the base of the middle basalt series. Vágar. $\times 13$.

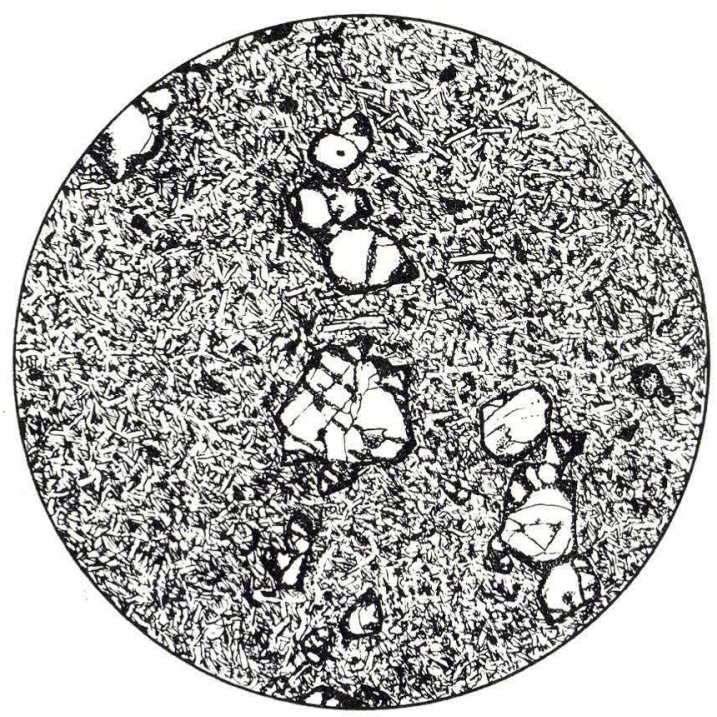

Fig. 4 f. Olivine tholeiitic basalt with stout phenocrysts of olivine. Upper basalt series. $\times 14$. 
A brief description of the various horizons is given below; a more detailed description is given in the respective sections.

The A-horizon coincides with the boundary between the lower basalt series and the coal-bearing sequence. The spot heights measured correspond to the lower limit of the coal-bearing sequence. In the field the boundary zone can be seen at the base of a vegetation-covered slope between the type of landscape characterized by "broad steps", which is prevalent in the lower basalt series, and the generally steeper, often bare, mountainside, which is characteristic of the transition to the middle basalt series. The boundary itself is nearly always covered by scree and vegetation. Naturally occuring outcrops are only found in steep mountain walls facing the sea. Inland, however, the boundary can be recognized in mines where coal is being worked and in a few still-open trial adits, where it has been exposed during search for coal. (p. 20.)

The B-horizon is not a natural geological boundary. It has been introduced purely for purposes of correlation and corresponds to the lower limit of a characteristic series of basalt flows with large areal extent and a certain "step-forming" appearance, which were selected for this purpose.

The typical succession over most of the area where it occurs is as follows. The rocks below the horizon consist of large-grained feldspar basalt, which is often, but not always, overlain by a red tuff. The horizon basalt consists of a variable number of rather thin flows of compact, hard, blue basalt separated by zeolite-filled vesicular zones; flow structure is common. The overlying rocks consist of finely speckled feldspar basalt.

The lower limit of the horizon basalt is shown on the map by means of a dotted line. It occurs about two-thirds of the way up in the middle basalt series. Where the horizon basalt is absent locally, the level is shown by means of a dotted line with double spacing between the dots. (p. 21.)

The C-horizon corresponds to the boundary between the middle and upper basalt series, and will therefore be described in more detail in the section on the upper basalt series. At this stage only the typical sequence in the boundary zone between the two series will be given. This is as follows. The rocks below the marker horizon consist of large-grained feldspar basalt; the plagioclase phenocrysts are often lath-shaped. The large-grained feldspar basalt is overlain by red tuff (not uncommonly with indeterminable imprints of 
plants). The horizon basalt consists of compact, blue basalt, often showing flow structure. It is common to find a series of two, three or more flows separated by zeolite-filled vesicular horizons, or occasionally thin tuff layers.

Nearly everywhere the top of the horizon basalt, and occasionally the base also, is marked by a scoriaceous agglutinate with a light bluish-violet colour. The rocks overlying the horizon basalt consist of finely speckled feldspar basalt. In addition to being shown by the colour boundary on the map (middle basalt series - upper basalt series) the C-horizon is shown by means of a black line (the lower limit of the horizon basalt). Where the horizon basalt was hard to follow because of poor exposure the line is broken, and where it is totally absent or its presence is very uncertain the level is retained in the form of a dotted line. (p. 23.)

Auxiliary marker horizons. As mentioned earlier (p. 11), auxiliary marker horizons were introduced to assist in linking up laterally displaced partial profiles. These horizons have the same symbol on the map as the B-horizon.

The lavas can, in general, be divided into the following three main groups (see fig. 4, a-f):

1. Aphyric basalts = basalts without macroscopically visible phenocrysts.

2. Porphyritic basalts (plagioclase-porphyritic basalts) $=$ basalts with larger or smaller phenocrysts of plagioclase.

3. Olivine-bearing basalts $=$ basalts with clearly visible olivine, predominantly in the form of phenocrysts.

Sampling in the main profile was undertaken with the primary object of enabling a petrographic (and chemical) analysis of the rocks to be made. The auxiliary profiles were measured partly to give reasonably representative information about the lava sequence throughout the Faeroe Islands and partly to give information about the geology locally as an aid to those who might use the map in the future.

The ideal profile (main profile)

With the aid of the marker horizons, the A-, B-, and C-horizons, and the auxiliary marker horizons, which were used to link up complete or partial profiles, it has been possible to produce a 


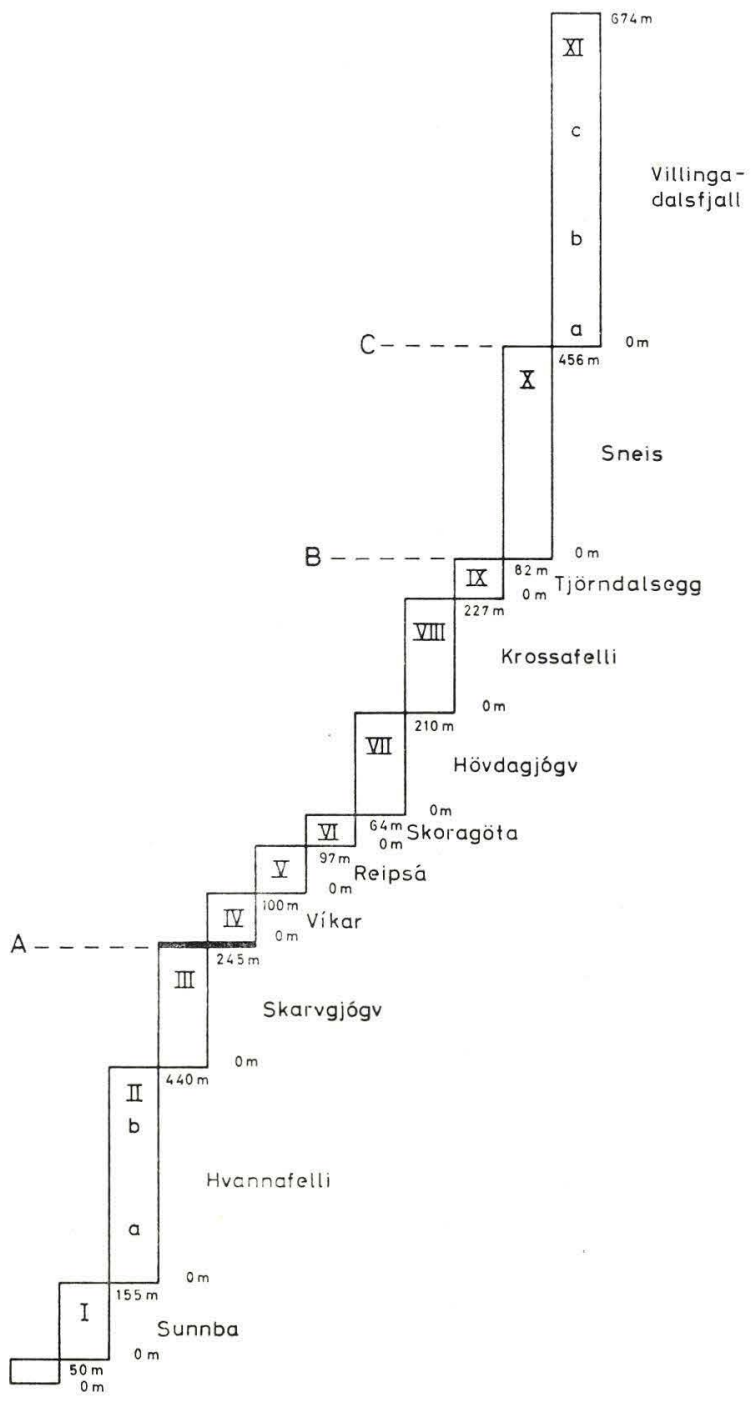

Fig. 5. The main profile. 
continuous main profile - an ideal profile - through the entire lava pile.

Since the dip on Suðuroy ranges mainly from NNE to NE to ENE and on the northern islands mainly from ESE to SE, the individual profiles, which are shown on the map as I (the south-western part of Suðuroy) - XI (the northern part of Viðoy) do not constitute collectively a vertical profile at the same position in the sequence, but a series of vertical profiles that are laterally displaced in a northerly or easterly direction.

The relation between the individual profiles, which together make up the ideal profile, can be seen from the sketch profile (fig. 5). In this account each profile has been assigned a locality name and Roman numeral as follows:

I The Sunnba profile

II The Hvannafelli profile

III The Skarvgjógv profile

IV The Víkar profile

V The Reipsá profile

VI The Skoragøta profile

VII The Høvdagjógv profile

VIII The Krossafelli profile

IX The Tjørndalsegg profile

$\mathrm{X} \quad$ The Sneis profile

XI The Villingadalsfjall profile

While all the profiles in the middle and upper basalt series have been correlated by means of the A-, B-, and C-horizons and the auxiliary marker horizons shown on the map, it was attempted to correlate the profiles in the lower basalt series by calculation and construction.

By adding up the measured profiles we arrive at a total thickness of $2,800 \mathrm{~m}$ for the lava pile. When the necessary correction is made for the dip of the Vágar profiles, about $125 \mathrm{~m}$, a total thickness of $2,925 \mathrm{~m}$ is arrived at for the lavas. (Note that the coalbearing sequence and tuff-agglomerate zone are not included in this total and that in fig. 2 no correction has been made for the dip of the Vágar profiles.) 
Lower basalt series

Inaccessible mountain wall north of Sunnba .... about $50 \mathrm{~m}$

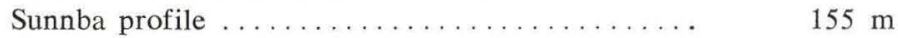

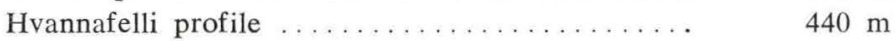

Skarvgjógv profile ................... $245 \mathrm{~m} \quad 890 \mathrm{~m}$

Middle basalt series

Víkar profile ...................... $100 \mathrm{~m}$

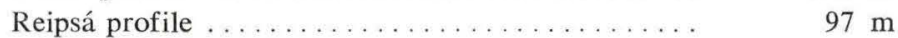

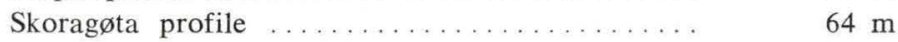

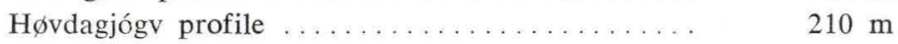

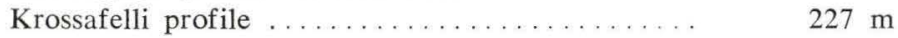

Tjørndalsegg profile ................ $82 \mathrm{~m}$

Sneis profile .................... $456 \mathrm{~m} \quad 1,236 \mathrm{~m}$

Upper basalt series

Villingadalsfjall profile

\begin{tabular}{rrr}
\cline { 2 - 3 } & $674 \mathrm{~m}$ & $674 \mathrm{~m}$ \\
\cline { 2 - 3 } & Total & $2,800 \mathrm{~m}$ \\
& $125 \mathrm{~m}$ & $125 \mathrm{~m}$ \\
\hline & Total & $2,925 \mathrm{~m}$
\end{tabular}

Since it can be of importance to future field work that the various observation points marked on the map can be located in the field, these have been listed in the following table, which gives height above sea level, number of the topographic map sheet and a description of the locality.

The reference to the topographic map sheet is in the form of two numbers, e.g. 47,7. The first number is that of the whole map sheet. Each map sheet has been divided into nine parts and the second number shows the part referred to (see fig. 6).

\begin{tabular}{|c|c|c|}
\hline 1 & 2 & 3 \\
\hline 4 & 5 & 6 \\
\hline \hline ये & 8 & 9 \\
\hline
\end{tabular}

Fig. 6. Division of map sheets. 


\begin{tabular}{|c|c|c|}
\hline $\begin{array}{c}\text { Height } \\
\text { in metres }\end{array}$ & $\begin{array}{l}\text { Map } \\
\text { sheet }\end{array}$ & Locality*) \\
\hline 310 & 50.1 & East side of Hovstúgva at spring. \\
\hline 400 & 49.3 & West side of Kolheyggjur. \\
\hline 412 & 47.7 & Westernmost mine adit north of Fámjin. \\
\hline 342 & 47.7 & At southernmost stream in Rossarók. \\
\hline 316 & 47.4 & At northernmost stream in Rossarók. \\
\hline 295 & 47.4 & Mine adit west of fault line at Botnsskarð. \\
\hline 305 & 47.4 & Mine adit just west of westernmost stream in Rangibotnur. \\
\hline 302 & 47.4 & North-east side of Mót. \\
\hline 267 & 47.8 & Old mine adit in north-east side of Oyrnafjall. \\
\hline 390 & 47.8 & At stream with spot height 390 west of Valdaskarð. \\
\hline 275 & 47.4 & At southernmost stream on west side of Tindur. \\
\hline 240 & 46.6 & North of Skarvgjógv. \\
\hline 180 & 46.3 & Suðuri undir Hæli (east of Bergstangi). \\
\hline 135 & 46.3 & Undir Bergsleiti (south of Heygsmúli). \\
\hline 65 & 46.3 & At pasture boundary, $\varnothing \mathrm{kslin}$ \\
\hline 110 & 46.3 & $\begin{array}{l}\text { At northernmost stream (south of spot height 280), east } \\
\text { side of Prestfjall. }\end{array}$ \\
\hline 176 & 46.3 & $\begin{array}{l}\text { At stream with spot height } 150 \text {, south-east side of Prest- } \\
\text { fjall. }\end{array}$ \\
\hline 156 & 47.1 & At stream north of dyke ( $\mathrm{Su} 8)$ in Rókhagi. \\
\hline 124 & 47.1 & $\begin{array}{l}\text { Stream with spot height } 270 \text { (northern branch) in Rók- } \\
\text { hagi. }\end{array}$ \\
\hline 45 & 47.1 & Flekksá. \\
\hline 0 & 44.7 & Tjørnunes. \\
\hline 0 & 47.2 & South of Stapin, Hvannhagi. \\
\hline 0 & 47.2 & Hvannhagi south. \\
\hline 0 & 48.7 & Hellið (south of Froðbiarnípa). \\
\hline 120 & 47.5 & $\varnothing$ kslin. \\
\hline 202 & 47.4 & Hvannagjógv. \\
\hline 66 & 43.9 & West side of Grímsfjall. \\
\hline 0 & 43.9 & Kolaratangi. \\
\hline 0 & 43.9 & Old landing place, Hvalba. \\
\hline
\end{tabular}

\begin{tabular}{rrl}
\hline $\begin{array}{c}\text { Height } \\
\text { in metres }\end{array}$ & $\begin{array}{c}\text { Map } \\
\text { sheet }\end{array}$ & Locality \\
\hline 0 & 24.5 & South of Âlkuklettur. \\
120 & 24.1 & At fence round field, Gásadalur. \\
278 & 17.7 & South of Barðið (Gilið á Dýpinum). \\
0 & 24.2 & West side of Viðvík (Víkar).
\end{tabular}

* For place names not found on the geological map reference is made to the topographic map at $1: 20,000$. 


\begin{tabular}{ccl}
\hline $\begin{array}{c}\text { Height } \\
\text { in metres }\end{array}$ & $\begin{array}{c}\text { Map } \\
\text { sheet }\end{array}$ & Locality \\
\hline 370 & 30.2 & Krákureyn, at parish boundary. \\
404 & 25.8 & Stream with spot height 400 coming from Reynsatindur. \\
474 & 25.5 & At profile IX north of Tjørndalsegg. \\
338 & 25.6 & In watercourse east of Reynini. \\
220 & 30.3 & Stream south of Fossá. \\
243 & 25.9 & In stream at Smyrlagjógv. \\
215 & 26.4 & In watercourse in Kálvadalur. \\
120 & 31.1 & Continuation of Oknadalsgjógv.
\end{tabular}

\begin{tabular}{ccc}
\hline $\begin{array}{c}\text { Height } \\
\text { in metres }\end{array}$ & $\begin{array}{c}\text { Map } \\
\text { sheet }\end{array} \quad$ Locality \\
\hline
\end{tabular}

026.5 South of small gjógv* south of Vađsteinagjógv.

$38 \quad 26.2$ Above bridge over Leynará, about $50 \mathrm{~m}$ south of ból** on north side of stream.

$118 \quad 26.1$ Víkará, Kvívík.

$221 \quad 25.3 \quad$ Stream flowing towards Sunnaragjógv.

$292 \quad 18.9$ South-south-west of trigonometrical station 317 on $\emptyset$ kslin.

$164 \quad 19.7$ In Heljareyga just east of Rangagjógv.

$270 \quad$ 18.6 At first watercourse east of pipeline leading down to power station at Fossá.

$250 \quad 18.6 \quad$ In north side of gully in Bjarnadalsá.

$298 \quad 18.3 \quad$ In main watercourse going towards Vatnið.

$325 \quad$ 18.6 At path leading up towards Dalkinn.

334 18.6 At SSW-NNE trending fence on small hillock south of Dalkinn.

$400 \quad 18.2 \quad$ In stream (with spot height 410) up towards Snædalur.

$390 \quad 11.8 \quad$ In E-W trending gjógv south of Giljar.

$338 \quad 11.9$ In stream with spot height 400 at pasture and parish boundary.

$284 \quad 11.9$ Just west of spot height 280.

$245 \quad 11.9$ Klovsá.

$100 \quad 19.1$ Stream east of Bjendalsfossar, which runs out in Stórá at spot height 18 .

$0 \quad 19.2$ Just east of boathouses on south side of Hvalvík.

* gjógv (Faeroese): steep-sided gully.

** ból (Faeroese): enclosure for sheep in pasture land. 


\begin{tabular}{ccc}
\hline $\begin{array}{c}\text { Height } \\
\text { in metres }\end{array}$ & $\begin{array}{c}\text { Map } \\
\text { sheet }\end{array}$ Locality \\
\hline
\end{tabular}

$510 \quad 11.8$ South of spot height 555 at gjógv south of Urđardrangur.

$466 \quad 11.5$ Westernmost branch of stream in Skoradalur.

$361 \quad 11.5$ Stream in Vatnsdalur.

$282 \quad 11.6 \quad$ North of Svínagjógv.

$365 \quad 11.8$ Reyná.

$445 \quad 11.8$ South-south-west corner of Pætursfjall, just below spot height 464.

$0 \quad 19.2 \quad$ About $450 \mathrm{~m}$ south of Grønhólmur.

$143 \quad 12.7$ Streymnesfossar.

$250 \quad 11.6$ Tvørá.

$308 \quad 11.2$ Eastern end of fence at path leading to Tjørnuvík.

$362 \quad 11.2$ At westernmost stream branches down towards Ostagjógv.

$383 \quad 11.2$ Facing sea above spot height 346 , on south side of valley at Svínaskorá.

3835.8 South-west of spot height 280 on south side of Nororaridalur.

$227 \quad 5.5 \quad$ Steep cliff between Sjendir and Mýlingur.

$293 \quad 5.5$ Stream with spot height 360 in Svarthamar.

$310 \quad 5.8 \quad$ South end of Svarthamar.

$285 \quad 5.8$ South-westernmost tributary of Brekká.

$268 \quad 5.8 \quad$ South-easternmost tributary of Brekká.

$298 \quad 5.8 \quad$ At end of escarpment north-west of spot height 320.

$265 \quad 5.8 \quad$ Path leading to Sjendir.

$225 \quad 5.5$ At gjógv on east side of Sjendir (wall on south side of gjógv).

$185 \quad 5.5$ At gjógv on east side of Sjendir (wall on north side of gjógv).

$160 \quad 5.6$ North of stream with spot height 180 north of Rangagjógv.

$168 \quad 5.9$ At stream running south of stream with spot height 220, down towards boathouses on west side of Tjørnuvík.

$203 \quad 5.9$ In stream running down from Mýrin in large gjógv.

1365.6 North-west of spot height 180 north of Lundagjógv.

$122 \quad 6.7$ At path leading up from Haldórsvík, east of spot height 150 .

$118 \quad 12.1$ About $100 \mathrm{~m}$ south of Fossá.

$87 \quad 12.8 \quad$ Norðaragjógv (wall on south side of gjógv).

$0 \quad 19.2$ In cultivated area opposite Oyrarbakki, Eysturoy. 


\begin{tabular}{rrl}
\hline $\begin{array}{c}\text { Height } \\
\text { in metres }\end{array}$ & $\begin{array}{c}\text { Map } \\
\text { sheet }\end{array}$ & Locality \\
\hline 61 & 6.4 & $\begin{array}{l}\text { On south-western side of fault between Múlaklettur and } \\
\text { Skíndalsklettur. }\end{array}$ \\
0 & 12.8 & $\begin{array}{l}\text { South of field in Norðskáli (at spot height 12 on map). } \\
\text { Stream (with spot heights 10 and 130) north of field in } \\
65\end{array} 12.5$ \\
63 & 12.2 & $\begin{array}{l}\text { Svínáir. } \\
\text { In stream, Ljósá. } \\
60\end{array}$ \\
6.7 & In Hellisá. \\
0 & 6.4 & $\begin{array}{l}\text { Stream (with spot height 49) between Mølin and Trølls- } \\
\text { høvdið. }\end{array}$
\end{tabular}

\begin{tabular}{cc}
\hline $\begin{array}{c}\text { Height } \\
\text { in metres }\end{array}$ & $\begin{array}{c}\text { Map } \\
\text { sheet }\end{array}$ Locality \\
\hline
\end{tabular}

$040.6 \quad$ Just north of landing place, Skúvoy.

11740.2 Just south-east of spot height 132, Høvdin.

$040.3 \quad$ North of Skarvagjógv.

\begin{tabular}{rrl}
\hline $\begin{array}{c}\text { Height } \\
\text { in metres }\end{array}$ & $\begin{array}{c}\text { Map } \\
\text { sheet }\end{array}$ & Locality \\
\hline 0 & 38.5 & North of stream with spot height 20, Svínadalur. \\
64 & 38.4 & South of Alarnir (north of spot height 73). \\
30 & 38.1 & Stream (with spot height 10) in Søltuvík. \\
47 & 38.1 & North-western corner of fence round field in Søltuvík. \\
140 & 37.1 & In stream with spot height 60 (eastern branch of stream) \\
& & at Rættin, north point of Sandoy. \\
90 & 37.4 & East of Erskoraklettur (west of small stream). \\
25 & 37.4 & At northern end of lake at Stórihøvdi. \\
0 & 37.4 & Just south-east of Harðaberg.
\end{tabular}

\begin{tabular}{cccc} 
C-horizon & & Hestur \\
\hline $\begin{array}{c}\text { Height } \\
\text { in metres }\end{array}$ & $\begin{array}{c}\text { Map } \\
\text { sheet }\end{array}$ & Locality & \\
\hline
\end{tabular}

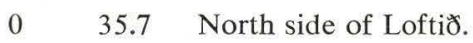

$62 \quad 35.4$ At fence south of Ormur.

$0 \quad 35.4 \quad$ About $200 \mathrm{~m}$ north of landing place. 


\begin{tabular}{ccl}
\hline $\begin{array}{c}\text { Height } \\
\text { in metres }\end{array}$ & $\begin{array}{c}\text { Map } \\
\text { sheet }\end{array}$ & Locality \\
\hline 124 & 34.3 & $\begin{array}{l}\text { South-western end of fence (at spot height 124). } \\
\text { In second-farthest west of watercourses (at spot height } \\
188\end{array}$ \\
$\begin{array}{ll}\text { 190). } \\
\text { North-eastern end of fence (at spot height 119). }\end{array}$
\end{tabular}

\begin{tabular}{|c|c|c|}
\hline $\begin{array}{c}\text { Height } \\
\text { in metres }\end{array}$ & $\begin{array}{l}\text { Map } \\
\text { sheet }\end{array}$ & Locality \\
\hline 0 & 35.1 & At Hiplingshøvdi, north of Velbastaður. \\
\hline 130 & 32.4 & $\begin{array}{l}\text { About } 100 \mathrm{~m} \text { north of stream from Fólkaskarð, Norðra- } \\
\text { dalur. }\end{array}$ \\
\hline 144 & 32.1 & $\begin{array}{l}\text { Westernmost stream branch (with spot height 220) below } \\
\text { Neytaskarð, Norðradalur. }\end{array}$ \\
\hline 385 & 26.9 & $\begin{array}{l}\text { In watercourse just east of small lake (with spot height } \\
355 \text { ) on north side of Gjáarbotnur. }\end{array}$ \\
\hline 410 & 26.6 & In gully on west side of Trantur. \\
\hline 370 & 26.6 & $\begin{array}{l}\text { On east side of Stórareyn at second cairn north of spot } \\
\text { height } 347 \text { (cairn). }\end{array}$ \\
\hline 225 & 26.6 & Hórisgøta. \\
\hline 167 & 27.4 & Waterfall in stream just east of path up from Signabøur. \\
\hline 150 & 27.5 & Jøkilsgjógv. \\
\hline 0 & 27.9 & South of ból south of Krákugjógv. \\
\hline 0 & 32.2 & A few hundred metres west of fence round field, Sund. \\
\hline 103 & 32.1 & $\begin{array}{l}\text { About } 100 \mathrm{~m} \text { south-east of stream with spot height } 150 \text {, } \\
\text { Kaldbaksbotnur south. }\end{array}$ \\
\hline 160 & 27.7 & $\begin{array}{l}\text { Fjarđará (main stream from Mannafellsdalur), Kaldbaks- } \\
\text { botnur. }\end{array}$ \\
\hline 68 & 32.1 & Gorrtalagjógv. \\
\hline 0 & 32.2 & About $600 \mathrm{~m}$ west-south-west of landing place, Kaldbak. \\
\hline 420 & 26.5 & Klettsgjógv (east side). \\
\hline 450 & 26.5 & Just west of dyke (Str. 217) on south side of Sátan. \\
\hline 495 & 26.2 & About $40 \mathrm{~m}$ south of watercourse south of Navirnar. \\
\hline 480 & 26.2 & East side of Navagjógv. \\
\hline 362 & 26.3 & Djúpagil · \\
\hline 465 & 19.8 & Gorge (west of spot height 557) in continuation of dyke. \\
\hline 568 & 19.5 & Westernmost point of Bollin. \\
\hline 425 & 19.9 & In Smørdalsá (Hósvík). \\
\hline 261 & 27.1 & Just east of trigonometrical station 266 east of Miðgerðaá. \\
\hline 278 & 27.1 & In Kirkjuá. \\
\hline 265 & 27.1 & $\begin{array}{l}\text { In stream east of spot height } 280 \text { on north-east side of } \\
\text { Dyllan. }\end{array}$ \\
\hline 566 & 19.8 & South-east point of Stígarnir. \\
\hline 633 & 19.4 & North-west point of Sneis. \\
\hline
\end{tabular}




\begin{tabular}{|c|c|c|}
\hline $\begin{array}{c}\text { Height } \\
\text { in metres }\end{array}$ & $\begin{array}{l}\text { Map } \\
\text { sheet }\end{array}$ & Locality \\
\hline 0 & 27.6 & About $1.1 \mathrm{~km}$ south of Kolbjarnargjógv. \\
\hline 166 & 27.2 & In Tungáir (westernmost stream). \\
\hline 282 & 20.8 & In Gjógvará (south side). \\
\hline 332 & 20.4 & East-north-east of spot height 260, Rókin. \\
\hline 476 & 20.1 & Stream flowing into Oyrargjógv at spot height 383. \\
\hline 490 & 19.3 & In stream with spot height 440 west of Oyrarskarð. \\
\hline 498 & 12.9 & $\begin{array}{l}\text { Just east of stream with spot height } 480 \text { south-east of } \\
\text { Nøvin. }\end{array}$ \\
\hline 505 & 12.9 & $\begin{array}{l}\text { About } 100 \mathrm{~m} \text { west of spot height } 520 \text { on north-west } \\
\text { side of Nøvin. }\end{array}$ \\
\hline 513 & 12.9 & $\begin{array}{l}\text { At parish and pasture boundary south of Skarðið undir } \\
\text { Nøvini. }\end{array}$ \\
\hline 470 & 13.7 & Just north of Lokkafellsgjógv. \\
\hline 458 & 13.7 & Just south of Lokkafellsgjógv. \\
\hline 410 & 13.7 & $\begin{array}{l}\text { Just south of cairn (with spot height 405) south-west } \\
\text { of Skálafjall. }\end{array}$ \\
\hline 428 & 13.7 & $\begin{array}{l}\text { Westernmost part of Skálafjall (about } 50 \mathrm{~m} \text { west of } \\
\text { stream that flows towards Fjarðará). }\end{array}$ \\
\hline 428 & 13.7 & Directly north of westernmost lake on Skálafjall. \\
\hline 415 & 13.7 & On north-east corner of Skálafjall. \\
\hline 415 & 13.7 & In gully between two streams on south side of Skálafjall. \\
\hline 384 & 20.1 & Northernmost branch of stream leading to Svínagjógv. \\
\hline 332 & 20.2 & At path leading to cairn on Skálabotnur. \\
\hline 260 & 20.6 & Hagagjógv. \\
\hline 184 & 20.9 & Skálagerđisá. \\
\hline 80 & 27.3 & In small stream north of Ljósá. \\
\hline 0 & 27.6 & Headland south of Heygsstøð. \\
\hline 525 & 12.9 & $\begin{array}{l}\text { At end of escarpment about } 100 \mathrm{~m} \text { west of stream with } \\
\text { spot height 530, Lítlafelli. }\end{array}$ \\
\hline 525 & 12.6 & $\begin{array}{l}\text { At parish and pasture boundary on north-west corner of } \\
\text { Lítlafelli. }\end{array}$ \\
\hline 521 & 12.9 & Just above gjógv on south-east corner of Lítlafelli. \\
\hline 564 & 12.6 & $\begin{array}{l}\text { At end of escarpment (south of spot height 570) on } \\
\text { south-west corner of Miðalfelli. }\end{array}$ \\
\hline 570 & 12.6 & $\begin{array}{l}\text { About } 100 \mathrm{~m} \text { south of parish and pasture boundary } \\
\text { (with spot height 570) on north-west corner of Miðalfelli. }\end{array}$ \\
\hline 545 & 12.6 & $\begin{array}{l}\text { At parish and pasture boundary on south-east corner of } \\
\text { Miðalfelli. }\end{array}$ \\
\hline 581 & 12.6 & $\begin{array}{l}\text { On south side of Skerðingur at parish and pasture } \\
\text { boundary. }\end{array}$ \\
\hline 600 & 12.3 & $\begin{array}{l}\text { At parish and pasture boundary south-east of Oknadals- } \\
\text { skaro. }\end{array}$ \\
\hline 574 & 12.6 & In Harðbaksenni (on east side of Skerðingur). \\
\hline 605 & 12.3 & $\begin{array}{l}\text { At parish and pasture boundary north of Oknadals- } \\
\text { skaro. }\end{array}$ \\
\hline
\end{tabular}




\begin{tabular}{ccc}
\hline $\begin{array}{c}\text { Height } \\
\text { in metres }\end{array}$ & $\begin{array}{c}\text { Map } \\
\text { sheet }\end{array}$ Locality \\
\hline
\end{tabular}

$620 \quad 12.2$ On south-west corner of Svartbakstindur (at southern end of escarpment east of spot height 520).

$615 \quad 12.2$ At field boundary due west of top (792 m) of Blámannsfjall.

$605 \quad 6.8$ At parish and pasture boundary south-east of Vatndalsskarø.

$583 \quad 6.9$ At pasture boundary south-south-east of Nón (east of spot height 600).

$602 \quad 12.3$ At pasture boundary (east of spot height 720 ) on east side of Blámannsfjall.

$610 \quad 6.8$ At parish and pasture boundary on south-east corner of Vaðhorn.

$634 \quad 6.8$ On west side of Vaohorn at spot height 640.

$608 \quad 6.8$ At parish and pasture boundary on north side of Vaðhorn.

5956.5 South-west of Hálsur (Slættaratindur) just above spot height 590 .

$553 \quad 6.5$ Just south of stream with spot height 560 in $\varnothing \mathrm{ksnadalur}$.

$576 \quad 6.5$ North-north-west of trigonometrical station 612 on Mannssetur.

$507 \quad 6.6 \quad$ Stream in valley north of Gráfelli.

$460 \quad 6.2$ South-west of Hornfjall, just north of fence with spot height 460 .

$457 \quad 6.2 \quad$ North corner of Hornfjall.

465 6.3 At eastern end of escarpment west of Rivá in Ambadalur.

$460 \quad 6.3$ Due east of fence on north point of Nøvin.

$485 \quad 6.6$ About $100 \mathrm{~m}$ north-east of spot height 480 on southernmost part of Garðahamar.

$510 \quad 6.6 \quad$ On south-east point of Gráfelli.

5446.5 Fremra Dalsá (westernmost stream branch north of Bláberg).

$550 \quad 6.6$ At eastern corner of escarpment on south flank of Gívrarbotnur.

$445 \quad 6.3$ At northern end of fence (southern part of Múlin).

$432 \quad 6.3$ On Múlin (north).

$574 \quad 6.9$ At pasture boundary on west corner of Húsafjall.

$545 \quad 6.9$ Northern end of Húsafjall.

$562 \quad 6.9$ Southern end of Húsafjall.

$490 \quad 6.6$ South-west corner of Middagsfjall (south-west of spot height 520).

$451 \quad 6.6 \quad$ North-west corner of Middagsfjall.

$452 \quad 6.6$ East corner of Middagsfjall above Skúvadalsskarð.

$434 \quad 7.4 \quad$ South-west corner of Tyril. 


\begin{tabular}{|c|c|c|}
\hline $\begin{array}{l}\text { Height } \\
\text { in metres }\end{array}$ & $\begin{array}{l}\text { Map } \\
\text { sheet }\end{array}$ & Locality \\
\hline 426 & 7.1 & North corner of Tyril (below spot height 460 ). \\
\hline 0 & 28.4 & $\begin{array}{l}\text { About } 300 \mathrm{~m} \text { north of Saltnes (about } 50 \mathrm{~m} \text { south of } \\
\text { fence). }\end{array}$ \\
\hline 0 & 28.4 & Just east of ból on south side of bay at Heiðarnar. \\
\hline 0 & 28.1 & $\begin{array}{l}\text { At } 0 \mathrm{~km} \text { stone (north of Simonsen's warehouse, Heiðar- } \\
\text { nar. }\end{array}$ \\
\hline 33 & 28.1 & In stream flowing through large gjógv in Glyvrar. \\
\hline 90 & 21.7 & $\begin{array}{l}\text { On southern side of Lambareiði (south-east of cairn } \\
\text { with spot height } 61 \text { ). }\end{array}$ \\
\hline 48 & 21.7 & $\begin{array}{l}\text { South of fence on south side of field, Lambi (above ból } \\
\text { with fence at spot height } 10 \text { ). }\end{array}$ \\
\hline 0 & 28.2 & $\begin{array}{l}\text { About } 600 \mathrm{~m} \text { west-north-west of Lambanes (ból east of } \\
\text { stream with spot height } 150 \text { ). }\end{array}$ \\
\hline 0 & 21.8 & $\begin{array}{l}\text { Just west of stream with spot heights } 80 \text { and } 280 \text { on } \\
\text { Seyðhamar on the north side of Lambavík. }\end{array}$ \\
\hline 140 & 21.7 & $\begin{array}{l}\text { In southernmost stream (with spot height 10) in Sølmund- } \\
\text { arfjørður. }\end{array}$ \\
\hline 220 & 20.6 & $\begin{array}{l}\text { At parish and pasture boundary on south side of } \\
\text { Gøtueiði. }\end{array}$ \\
\hline 133 & 21.4 & In stream (northern stream branch in Djúpidalur). \\
\hline 85 & 21.5 & At Tungan. \\
\hline 0 & 21.8 & East of Skáktangi. \\
\hline 278 & 20.3 & South point of Knyklarnir. \\
\hline 351 & 13.8 & $\begin{array}{l}\text { At stream west of trigonometrical station } 364 \text {, south side } \\
\text { of Trælavatnaskaro. }\end{array}$ \\
\hline 380 & 13.8 & $\begin{array}{l}\text { Stream with spot height } 380 \text { west of path leading up } \\
\text { from Skálabotnur. }\end{array}$ \\
\hline 412 & 13.5 & At path on west side of Jøklaskarð. \\
\hline 417 & 13.5 & On west flank (on point itself) of Hjarđardalur. \\
\hline 405 & 13.2 & $\begin{array}{l}\text { North-west corner of Slættafjall (just north of spot height } \\
410 \text { ). }\end{array}$ \\
\hline 398 & 13.2 & South side of Fuglfjarðarskarð. \\
\hline 396 & 13.5 & $\begin{array}{l}\text { Tributary of Gjógvará on north side of } \mathbf{J} \phi \text { kladalur } \\
\text { (first stream east of spot height } 480 \text { ). }\end{array}$ \\
\hline 400 & 13.5 & In Gjógvará, on east side of Jøklaskarð゙. \\
\hline 348 & 13.8 & $\begin{array}{l}\text { Stream (parish and pasture boundary) flowing from } \\
\text { Trælavøtn into Kambsdalur. }\end{array}$ \\
\hline 460 & 13.4 & At pasture boundary on south-west side of Múlatindur. \\
\hline 470 & 13.4 & In stream with spot height 480 \\
\hline 465 & 13.1 & Just south of $\varnothing \mathrm{ksnagjógv.}$ \\
\hline 450 & 7.7 & $\begin{array}{l}\text { About } 100 \mathrm{~m} \text { south of telephone line between Maður } \\
\text { and Lyngstúgva. }\end{array}$ \\
\hline 428 & 7.7 & $\begin{array}{l}\text { On north-east corner of Lyngstúgva (just above spot } \\
\text { height } 420 \text { ). }\end{array}$ \\
\hline
\end{tabular}




\begin{tabular}{cc}
\hline $\begin{array}{c}\text { Height } \\
\text { in metres }\end{array}$ & $\begin{array}{c}\text { Map } \\
\text { sheet }\end{array}$ Locality \\
\hline
\end{tabular}

$451 \quad 13.1 \quad$ In northernmost tributary (stream branch with spot height 370) of Kvíggjará in Vatnsdalur.

$400 \quad 13.2 \quad$ North-east side of Veðurhorn.

$442 \quad 13.4$ In Laksá (southern wall of gjógv).

$438 \quad 13.4 \quad$ South-east of Múlatindur, about $50 \mathrm{~m}$ south of stream with spot height 470 .

$516 \quad 13.1 \quad$ North point of Hægstafjall (at Dalkinn).

$492 \quad$ 13.1 At stream (with spot height 410) on south-east side of Hægstafjall.

$257 \quad 21.1 \quad$ At path on west side of Lorvíksfjall.

$295 \quad 13.9$ Skoragjógv.

$277 \quad 14.7 \quad$ Fossagil.

14021.2 Above Hagaleiti (just beside spot height 140).

$95 \quad 21.3$ In Gøtunesgjógv (north side).

$391 \quad 13.2 \quad$ North of Fuglfjarðarskarð.

$391 \quad 13.2 \quad$ North-eastern part of Rustartindur (just above spot height 380 ).

$356 \quad 13.6$ Heimaragjógv (eastern stream branch).

$418 \quad 7.8$ South-west of trigonometrical station 504, Tindur.

$416 \quad 7.8$ South-east of trigonometrical station 504, Tindur.

$399 \quad 7.8$ On east side of Oyndfjarđarfjall (about $150 \mathrm{~m}$ south-east of spot height 360).

\begin{tabular}{ccc}
\hline $\begin{array}{c}\text { Height } \\
\text { in metres }\end{array}$ & $\begin{array}{c}\text { Map } \\
\text { sheet }\end{array} \quad$ Locality \\
\hline
\end{tabular}

$204 \quad 14.5 \quad$ East-south-east of Klubbin.

$254 \quad 14.4 \quad$ In first watercourse north-west of field in Blankskáli.

$262 \quad 14.1 \quad$ North-north-west of spot height 290 on Lágfjall.

24214.2 Gjógv with spot height 250 south of Húsar.

$241 \quad 14.2$ First stream north of Myllá in Knúksdalur.

$221 \quad 14.5$ Just west of spot height 180 north-west of Syðradalur.

$205 \quad 14.5$ South-west of Syðradalur, east of Knúkur.

$272 \quad 14.1$ In southern watercourse flowing into Rættargjógv northwest of Húsareið̃i.

$305 \quad 7.6$ West side of Keldurnar, just above spot height 280.

$308 \quad 7.3$ South-east of Heyggjurin Hvassi, at source of stream with spot height 180 .

$302 \quad 7.3$ Just north of spot height 341, Slættafjall.

$300 \quad 7.3$ On south side of Mikladalur (above stream branch in stream with spot height 157).

$290 \quad 7.3$ Corner of basalt flow due west of Ritudalsgjógv. 


\begin{tabular}{cc}
\hline $\begin{array}{c}\text { Height } \\
\text { in metres }\end{array}$ & $\begin{array}{c}\text { Map } \\
\text { sheet }\end{array} \quad$ Locality \\
\hline
\end{tabular}

$300 \quad 7.6$ On south side of Ritudalur, in gjógv north of Byttufelli.

$305 \quad 8.4$ In innermost part of Hattardalur.

2958.7 Southern side of Miðardalur, about $250 \mathrm{~m}$ east-southeast of spot height 300 .

$284 \quad 8.7$ On southern side of Leitisdalur; stream with spot height 190.

$268 \quad 8.7$ Just above fence on north of field, Húsar.

\begin{tabular}{ccc}
\hline $\begin{array}{c}\text { Height } \\
\text { in metres }\end{array}$ & $\begin{array}{c}\text { Map } \\
\text { sheet }\end{array} \quad$ Locality \\
\hline
\end{tabular}

$158 \quad 14.3$ Kunoyarnes (Brattanes), just above spot height 100.

$200 \quad 14.2$ In main stream in Hellisdalur.

2158.8 South-west corner of Hjarðardalur, above spot height 140.

$233 \quad 8.8$ West of Landsuðurknúkur, just below spot height 240 south-east of Kunoyarbygd.

$240 \quad 8.5$ North-west corner of Skarðdalur just above trigonometrical station 207.

$238 \quad 8.5 \quad$ South side of Skriðudalur (below spot height 450).

$236 \quad 8.2$ South side of Móisdalur, just above spot height 180.

$237 \quad 2.7$ Just below spot height 240 on south side of valley.

$238 \quad 2.8 \quad$ South-east corner of Ytstidalur at spot height 240.

$228 \quad 2.8$ In south-east corner of Gjóardalur at end of basalt flow.

2308.2 In south-east corner of Miklidalur, about $150 \mathrm{~m}$ southwest of spot height 210 .

$225 \quad 8.5$ South side of Skarðdalur at end of basalt flow.

2218.6 In gjógv with spot height 220 east of Líraskor.

$216 \quad 8.6 \quad$ In stream with spot height 110 south of Vøtnini.

$187 \quad 8.9$ Garðáir (main channel), Haraldsund.

$168 \quad 14.3$ In stream along fence with spot height 140.

\begin{tabular}{rrl}
$\begin{array}{c}\text { Height } \\
\text { in metres }\end{array}$ & $\begin{array}{c}\text { Map } \\
\text { sheet }\end{array}$ & Locality \\
\hline 0 & 21.3 & $\begin{array}{l}\text { About } 800 \mathrm{~m} \text { south of Ritugjógv. } \\
\text { In stream up towards Hálsur, between Klakkur and }\end{array}$ \\
130 & 14.6 & $\begin{array}{l}\text { Hálgafelli. } \\
\text { At watercourse with two branches inland from northern- } \\
\text { most quay. }\end{array}$
\end{tabular}




\begin{tabular}{ccc}
\hline $\begin{array}{c}\text { Height } \\
\text { in metres }\end{array}$ & $\begin{array}{c}\text { Map } \\
\text { sheet }\end{array} \quad$ Locality \\
\hline
\end{tabular}

$57 \quad$ 15.7 At fence on south of field (west side of Borðoyarvík).

$0 \quad 15.7 \quad$ At small fence north of Taravíkstangi.

$0 \quad 15.7$ South of Skálaberg (Norđoyri).

$65 \quad 15.4$ Gravará.

$120 \quad 15.1$ Ánagjógv.

$150 \quad 14.3 \quad$ Stórá.

1658.9 Svartidalur (main watercourse).

$160 \quad 8.6 \quad$ Krossdalsáir.

$173 \quad 8.3$ Watercourse (with spot height 136) in Húsadalur, south of Skálatoftir.

$1652.9 \quad$ Múlagjógv.

1462.9 East-north-east of trigonometrical station on Múlin.

1589.1 Stream with spot height 170 on south side of Argisdalur.

$150 \quad 9.1 \quad$ Krossdalsá.

$140 \quad 9.4$ Fossá.

1059.7 Toftá.

$0 \quad 15.2 \quad$ East-north-east of Toftamúli.

$0 \quad 15.4 \quad$ North side of Kvíingadalur.

$92 \quad 15.1 \quad$ Stream flowing down to Ārnafjøröur.

$0 \quad 15.5 \quad$ Lítlagjógv at Múlin.

\begin{tabular}{cc}
\hline $\begin{array}{c}\text { Height } \\
\text { in metres }\end{array}$ & $\begin{array}{c}\text { Map } \\
\text { sheet }\end{array} \quad$ Locality \\
\hline
\end{tabular}

$0 \quad 9.6 \quad$ South-east side of Viðoy.

$72 \quad 9.8$ At fence along stream on south side of island.

1259.5 At stream down towards south-east corner of fence south of Sandoyri.

$150 \quad 9.1$ Gjógv in continuation of Leitisgjógv.

$150 \quad 3.7 \quad$ North-west corner of Malinsfjall, below spot height 200 .

$110 \quad 9.2$ Southern branch of stream in Dalá.

$96 \quad 9.5 \quad$ Víkará.

$135 \quad 3.4 \quad$ Djúpagil.

$115 \quad 3.4$ At fence leading up from Hamarsgjógv. 


\section{Profiles}

In addition to tracing the marker horizons, which lie roughly in the plane of the map, we have measured many profiles, approximately at right angles to the contours, wherever on the islands this proved possible. This profile work was carried out throughout the period of study and by many different workers.

On p. 18 we pointed out that our main profile was built up from partial profiles, that it was chronologically correct, but that the lateral displacement of the partial profiles, which nature itself forced on us, means that the main profile does not represent a single, clear-cut vertical profile through the entire lava pile. On the contrary, it already became clear to us at an early stage in our work that there were considerable lateral variations in the makeup of the pile at the same stratigraphic level. Strictly speaking, therefore, the main profile shown on the map only has validity along the line of measurement and close to this line, because lava flows wedge out sideways and their place is taken by others.

In order to throw light on the lateral variations we selected from among our numerous profiles 36 that are well distributed throughout the entire island group. These 36 profiles are shown in fig. 7 in numerical order and have been positioned on the basis of the A-, B-, and C-horizons. The composite main profile (ideal profile) is shown on the left.

The marker horizons now enable us to make a comparison between lavas of the same age at various localities.

If we use the A-horizon as a marker horizon we can obtain data for the lavas of the lower basalt series. The partial profiles I, IIa, IIb and IV, which form part of the main profile, provide the main information about the succession, but profile 1 from Suðuroy, which more or less covers the same period of time as the lower part of profile IIa, and the profiles 4, 5, 6 and 7, which give data on the succession from Mykines to Tindhólmur and the western part of Vágar from west to east, are also of value. In particular we 


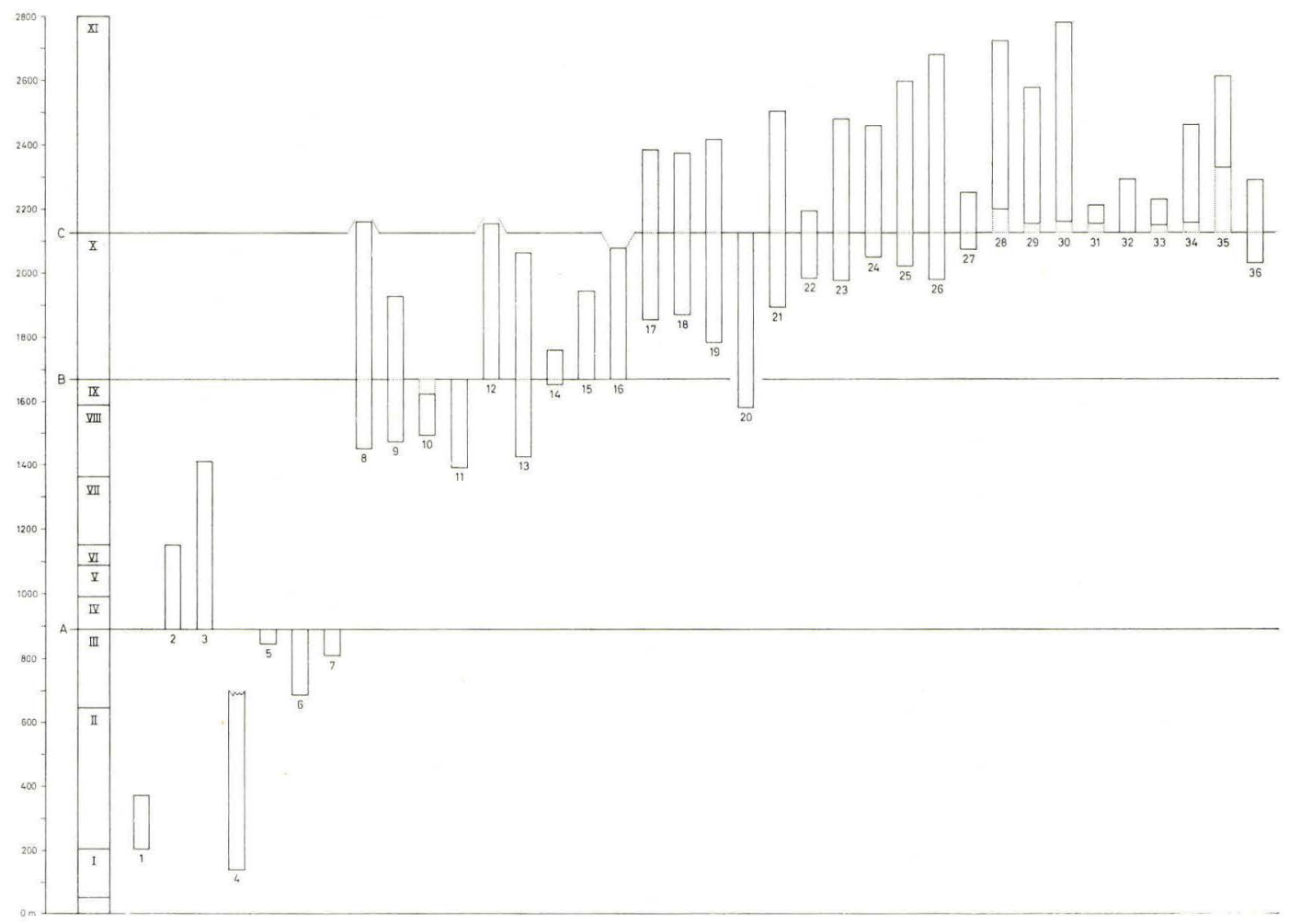

Fig. 7. The 36 auxiliary profiles with the main profile to the left. 
Auxiliary profiles

$\begin{array}{cl}\text { Profile } & \text { 1. Sunnba } \\ - & \text { 2. Hattur } \\ - & \text { 3. Sandvík } \\ - & \text { 4. Mykines } \\ - & \text { 5. Tindhólmur } \\ - & \text { 6. Streymnes } \\ - & \text { 7. Víkar } \\ - & \text { 8. Malinstindur } \\ - & \text { 9. Hægstafjall } \\ - & \text { 10. Hagagarđsá } \\ - & \text { 11. Heljardalsá } \\ - & \text { 12. Ørviksfelli } \\ - & \text { 13. Fossá } \\ - & \text { 14. Víkará } \\ - & \text { 15. Stykkið } \\ - & \text { 16. Gjógvin } \\ - & \text { 17. Breiðadalsá } \\ - & \text { 18. Dyllan }\end{array}$

$\begin{array}{cl}\text { Profile } & \text { 19. Deildará } \\ - & \text { 20. Miđalfelli } \\ - & \text { 21. Breiđá-Kambur } \\ - & \text { 22. Urđará } \\ - & \text { 23. Løgdalsá } \\ - & \text { 24. Hattardalstindur } \\ - & \text { 25. Kunoyarbygd } \\ - & \text { 26. Svartidalur } \\ - & \text { 27. Hálsur } \\ - & \text { 28. Torvadalsá } \\ - & \text { 29. Stórá } \\ - & \text { 30. Klubbin } \\ - & \text { 31. Hvíthamar } \\ - & \text { 32. Norđaraenni } \\ - & \text { 33. Skálsáklettar } \\ - & \text { 34. Reynsendi } \\ - & \text { 35. Tindur } \\ - & \text { 36. Skúvoy }\end{array}$

can assess the top part of the lower basalt series (III, 5, 6 and 7) just below the A-horizon.

The porphyritic top lava flow in profile III does not occur in 5, 6 and 7; considering the great distance - about $60 \mathrm{~km} \mathrm{-} \mathrm{be-}$ tween Suouroy and the northern group of islands this would hardly be expected. The top lava flow in 5 and 6 seems on the other hand to be the same, but it shows a different thickness in the two profiles. Profile 7 shows another type.

This could mean that the erosion reached various depths in the plateau, but it is perhaps more likely that the surface originally consisted of various lava flows at the time when the volcanism stopped for a while and the coal-bearing beds were laid down.

We can also use the A-horizon as a basis for comparing the lavas higher up - the lower half of the middle basalt series; the relevant profiles are the main profiles IV to VIII from Vágar and profiles 2 and 3 from Suðuroy.

When these profiles were compared it did not prove possible to correlate one single lava flow from the profiles in the north with any possible equivalent from the profiles in the south; on the other hand, it was noted that the more marked changes in the nature of the rocks were in general contemporaneous in both areas. However, there is one prominent difference in the nature of the porphyritic basalts in the northern and southern areas. The basalts in the north 
are crumbly and particularly difficult to obtain fresh samples from; those in the south are hard and compact and thus sampling here did not cause any difficulties.

The same procedure for comparisons between contemporaneous lavas from various localities was also attempted using the B- and C-horizons as marker horizons.

In this connection it is neccessary to draw attention to some apparent irregularities in the profiles 8, 12, 16 and 20 in the scheme, fig. 7.

In profile 8 from Malinstindur on Vágar the lavas of the Chorizon are lacking. This also applies to profile 12 from Ørviksfelli in the northern part of Streymoy; this was measured upwards, starting from the B-horizon, without the $\mathrm{C}$-horizon being reached. This must either mean that the thickness of the succession between the two horizons is greater here than the $450 \mathrm{~m}$ shown in the main profile or that the lava(s) of the C-horizon did not reach as far westwards.

Profile 16 is from Gjógvin, 5-6 km farther east, in the middle of Streymoy. Measuring of the profile started from the B-horizon and ended at the C-horizon. At this locality the distance between the two horizons is about $50 \mathrm{~m}$ less than in the main profile.

In profile 20 from Miðalfelli (Titlá) in the northern part of Eysturoy, which terminates upwards at the C-horizon, the geologist doing the mapping considered that he had not yet reached the Bhorizon at the base of the profile. He may be correct, but if so the distance between the two horizons at this locality is more than $100 \mathrm{~m}$ greater than in the main profile. In going through the profiles again, however, we have noted three lava flows in the lowest part of the profile, one of which could perhaps be a B-horizon lava flow; we have therefore allowed for both possibilities when we drew the profile.

The examples that have been given of irregularities emphasize the difficulties in working stratigraphically in an area built up of lens-shaped elements - most of whose boundaries are still unknown - and the care that must be shown in using purely petrographic criteria.

In general, however, we have noted that compact, bluish olivinebearing basalts in the upper part of the succession increase in amount to the north and especially to the east within the island group. 


\section{The lower basalt series}

The lower basalt series occurs on Suđuroy, Mykines, Gáshólmur, Tindhólmur and Vágar. The dip of the flows on Suðuroy is NNE, NE and ENE, and the highest flows of the lower basalt series reach sea level already along the north side of the island along the line Froðbiarnípa, Hvannhagi, Tjørnunes and Kolaratangi. The whole of the southern part of Suðuroy thus consists of lavas of the lower basalt series. The dip on Mykines varies from SE to ESE; on the western side of Vágar it is ESE. Mykines and Gáshólmur consist entirely of flows belonging to the lower basalt series, while only the westernmost part of Vágar and the lowermost part of Tindhólmur belong to this series, whose highest flows reach sea level on the eastern point of Tindhólmur and along the line Álkuklettur-Víkar on Vágar. The lower basalt series is built up of lava flows $10-30 \mathrm{~m}$ thick, with subordinate interbasaltic sediments, whose thickness seldom reaches $10 \mathrm{~m}$, and is usually considerably less. Thinner lava flows do occur, however, and a few flows as thick as $50-70 \mathrm{~m}$ can be seen. The rock is very uniform in character; it is a compact, hard, bluish basalt, which only exceptionally contains phenocrysts. It usually shows more or less well developed columnar structure, but this is seldom entirely regular. The surfaces of the flows are scoriaceous, vesicular and reddish. The total thickness of the series is not quite $900 \mathrm{~m}$.

\section{Suðuroy}

When one looks at the steep west coast of Suðuroy it is possible in naturally occurring, vertical sections, e.g. at Beinisvørður, Rávan and Vágseiði on the southern side of the island (lower part of the series), between Vágseiði and Fámjin (middle part of the series), and around Geitaskor-Prestkorar in the northern part of the island (upper part of the series), to obtain an excellent idea of the simple and regular geological makeup of the lower basalt series. The series shows regular alternation between basalt flows with scoriaceous surfaces and tuffs or other interbasaltic sediments. (Fig. 8.) 
The basalt flows between Sunnba and Vágseiði show in general a thickness that is about average for the lower basalt series, and have more or less clearly developed columnar structure and scoriaceous zones. The scoriaceous zones in the interval Akrabyrgi-Vágseiði often have an irregular course. Somewhat thinner lava flows can be seen, e.g. at Lónirnar north of Sunnba and south of Vágseiði. Erosion of flow tops and wedging-out of flows can be seen at various places, e.g. north of Bølluhálsur, north of Lomvigastakkur and south of Vágseiði. In the steep cliff around Beinisvørður there are many red tuff beds, which are, however, not very thick; the scoriaceous zones appear to have a much greater thickness. In Beinisvørður (469 m) about 20 basalt flows were counted from the sea.

Between Vágseiði and Fámjin the thickness of the basalt flows generally seems to be about the same as farther north. The tuffaceous and scoriaceous zones are usually sinuous and their top is irregular. Columnar structure is not always equally prominent, but for example at Forstólur a somewhat irregular columnar structure can clearly be seen throughout the whole of the mountain wall. In the steep, almost $300 \mathrm{~m}$ high mountain wall north of Vágseiði 15 flows were counted. South of Botnur the flows seem to be very regular with fairly uniform thickness. North of Botnur a flow can be seen to wedge out; its thickness is somewhat less than usual here, and its continuation northwards is sinuous; its thickness varies. Between Lađanbergstangi and Nakkurin Langi the flow thickness also varies somewhat, and a few flows can be seen wedging out.

Around Geitaskor and Prestskorar in the northern part of the island the same regular alternation between basalt flows and interbasaltic beds can be seen in the cliffs as in the southern part of the island. However, while in the south it is only the lower basalt series that we see, this series in the north only occupies the lower part of the cliffs; the upper part consists of the lavas of the middle basalt series; between the two series is the coal-bearing sequence, which is situated below a grass-covered ledge, see Geitaskor and Prestskorar (fig. 8).

The basalt lying below the coal-bearing sequence is a basalt with pronounced columnar structure. Its top is uneven and sinuous and shows clearly the effects of lengthy subaerial weathering. Columnar structure appears to be better developed in the uppermost part of the series than lower down - i.e. to the south. On the prism surfaces of the columns a pronounced cross-striping with drawn- 


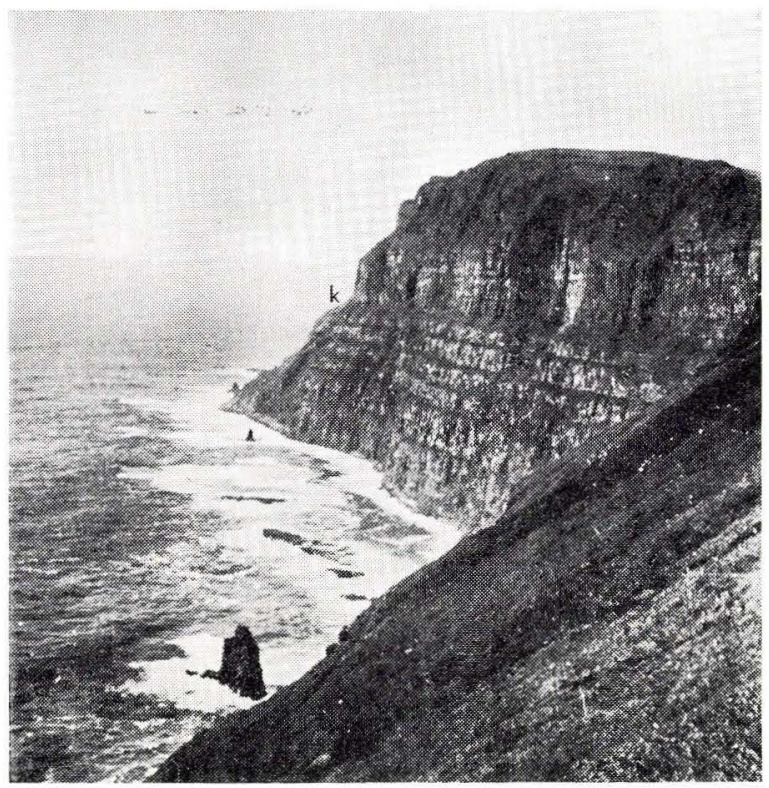

Fig. 8. West side of Suðuroy, Geitaskor and Prestskorar: Lower basalt seriescoal-bearing sequence $(k)$ - middle basalt series.

out vesicles can often be seen, which show up as grooves on weathered surfaces; the columns show a rather pronounced tendency to cleave in that direction. (See fig. 9.)

Amongst easily accessible localities for columnar basalts can be named the coast east of Froðba, Uttarihválur and Innarihválur on the north side of Trongisvágur and an old quarry in Trongisvágur, where the columns are particularly regular. In addition, they can be observed along the western side of the road between the villages of Øravík and Hov, where they often have irregular curved and twisted forms (fig. 10). At Kúlugjógv, east of Froðba, a body of agglomerate, which is overlain by a flow of columnar basalt, can be seen in the coast section. East and west of the agglomerate the columns are vertical, but towards the agglomerate they become more and more inclined and finally they stand approximately at right angles to the eastern and western boundaries of the agglomerate. Above the eroded central part of the agglomerate outcrop the columns form a fan. This locality, which has been known since early times and has often been described in the litera- 


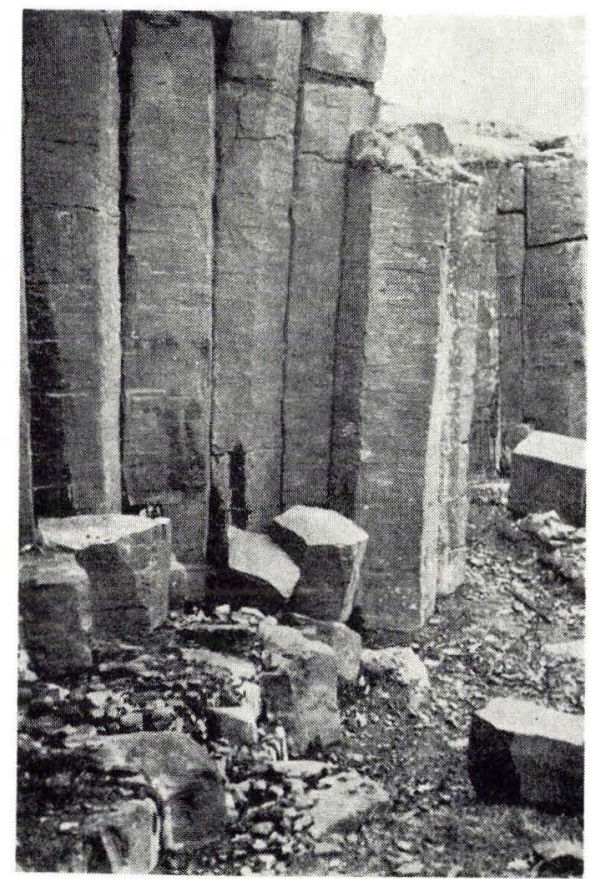

Fig. 9. Basalt columns in an old quarry at Trongisvágur.

ture, is described in more detail in Walker and Davidson (1936) and Rasmussen (1952). (See fig. 11.)

In order to obtain an idea of the thickness of the individual basalt flows two profiles were measured, one at Trongisvágsbotnur on the north-west side of Suðuroy and one at Skarvgjógv about 2 $\mathrm{km}$ farther north. Both profiles go from sea level up to the coalbearing sequence.

These profiles show that the flow thickness in the profile from Trongisvágsbotnur (13 flows) varies from $10-30 \mathrm{~m}$, with an average thickness of $18.5 \mathrm{~m}$. In the Skarvgjógv profile the average thickness of 10 flows is just under $20 \mathrm{~m}$, while the scoriaceous zones vary from a few metres to about $10 \mathrm{~m}$. The greatest thickness of a single basalt flow - about $50 \mathrm{~m}$ - was found in the mountain wall just north of Fámjin.

As already mentioned, the dip on Suðuroy is generally NNE, NE and ENE; however, on the north-west side of the island it is locally almost northwards and along the south coast it is almost eastwards. The steepest dip occurs towards the south-east coast, 


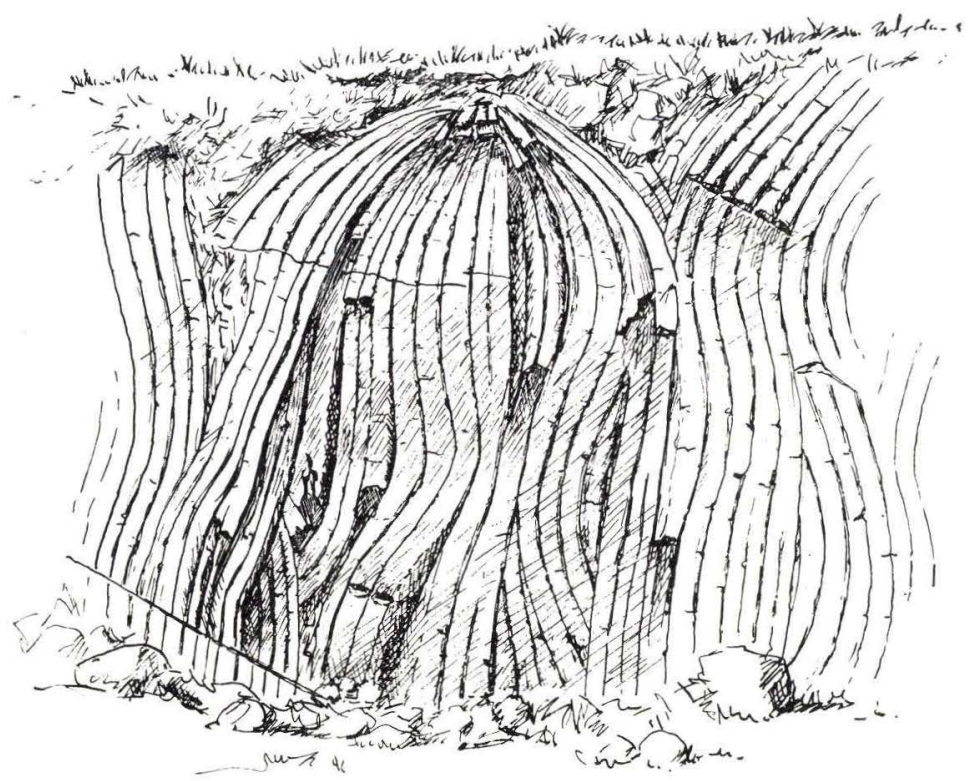

Fig. 10. Irregular columns above the village of Hov, Suduroy.

about $612^{\circ}$ (Porkerisnes and Víkarbyrgi), and the lowest dip, $3^{\circ}$, was found on the north-west side of the island. In the southern part of the island the dip is shown on the map with dip symbols. In the northern part it can easily be seen by means of the spot heights shown on the map for the lower boundary of the coalbearing sequence.

The interbasaltic sediments in the lower basalt series are essentially limited to tuffaceous and clayey sediments, shales, basaltic sandstone sediments and basaltic conglomerates.

The tuff beds vary greatly in colour. They are usually brownish or reddish, but occasionally are bright red. They can also be yellowish, green or grey-black in colour. The thickness usually varies from less than $1 \mathrm{~m}$ to $2-3 \mathrm{~m}$, but greater thicknesses are however not uncommon. In the profile from Trongisvágsbotnur the thinnest tuff bed was found to have a thickness of $1 \mathrm{~m}$ and the thickest a thickness of $4 \mathrm{~m}$. The average thickness was about $2.3 \mathrm{~m}$. Since the tuff beds overlie the very irregular scoriaceous zone of the underlying basalt flow, the thickness of the same tuff bed can be somewhat variable. Occasionally thin dykes of tuff occur as infillings in vertical fractures in the surface of the underlying basalt 


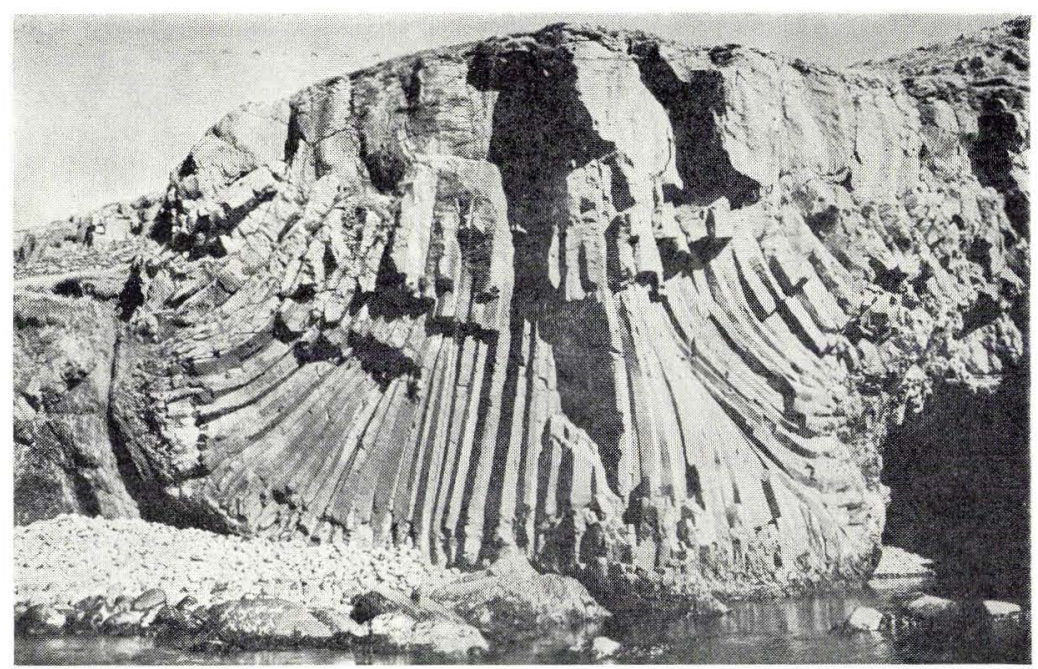

Fig. 11. Fan of basalt columns at Kúlugiógv, east of Frođba, Suðuroy.

flow. While the lower boundary of a tuff bed is usually a depositional boundary, the upper boundary often shows more or less pronounced signs of heat effects stemming from the overlying basalt flow. The heat effects can be quite weak, but often the uppermost part of the tuff bed and the lowermost part of the basalt flow can be seen to be completely welded together in the boundary zone, so that no sharp boundary can be seen, but on the contrary an even transition from tuff to basalt. In such cases the tuff takes on a bluish appearance in the boundary zone. If the tuff bed between two basalt flows is either almost absent or insignificant, the upper part of the scoriaceous zone between the two flows occurs as a vesicular, reddish-coloured welded horizon.

While the pure tuff is usually lacking in clear bedding and is more or less compact or hard according to the amount of heat it has been subjected to, we usually find a more distinct bedding in the clays, which on the other hand are more friable. The shale often has a bluish-black colour. Sandstones and conglomerates occur but are not as common in the lower basalt series as in the coal-bearing sequence.

Coal can often be found in these interbasaltic sediments. However, all such occurrences are either insignificant or quite sporadic; nevertheless, the presence of coal together with the sediments in 
which it occurs, indicates several pauses in the volcanicity that led to the formation of the lower basalt series.

On Suðuroy interbasaltic coal-bearing sediments were observed at the following localities:

On the west side of Grímsfjall, about $50 \mathrm{~m}$ above sea level.

Undir Bergsleiti, south-west of Hvalbiareið, about $115 \mathrm{~m}$ above sea level.

West of Tjørnunes, on the south side of Hvalbiarfjørður, at the coast.

In Hvannhagi, on the north-east side of Suouroy, in the bay west of Stapin.

At Innarihválur, on the north side of Trongisvágur.

Below the highest basalt flow in Fjallio Mikla, east of the village of Fámjin, at a height of about $428 \mathrm{~m}$.

In the steep cliff north of Fámjin, about $170 \mathrm{~m}$ above sea level, at Keppur.

Immediately south of Svínagjógv, between Borgin and Borgarknappur, at a height of about $480 \mathrm{~m}$.

On the west side of Hvannafelli about $520 \mathrm{~m}$ above sea level.

South of Hovshólmur, near the coast.

Just west of the road north of Porkeri, at a height of about $160 \mathrm{~m}$.

Below a waterfall in Áin Mikla, Porkeri, at a height of about $185 \mathrm{~m}$.

On the north side of Mýrifjørður (south-east side of Suðuroy).

\section{Mykines}

As already mentioned, Mykines consists entirely of flows belonging to the lower basalt series. As on Suðuroy the steep coasts on both the north and south sides of the island provide an excellent idea of the lava sequence, which in its makeup, flow thickness and structure resembles very closely the sequence on Suðuroy. The thickest basalt flow on Mykines, about $70 \mathrm{~m}$, was found at Hólmgjógv (the sound between Mykines and Mykineshólmur). On the south side of the island the top of a basalt flow is exposed along the beach; it is vesicular and contains chalcedony and calcite. The basalt is strongly jointed, and fractures striking in the prevalent dip direction are particularly common. 


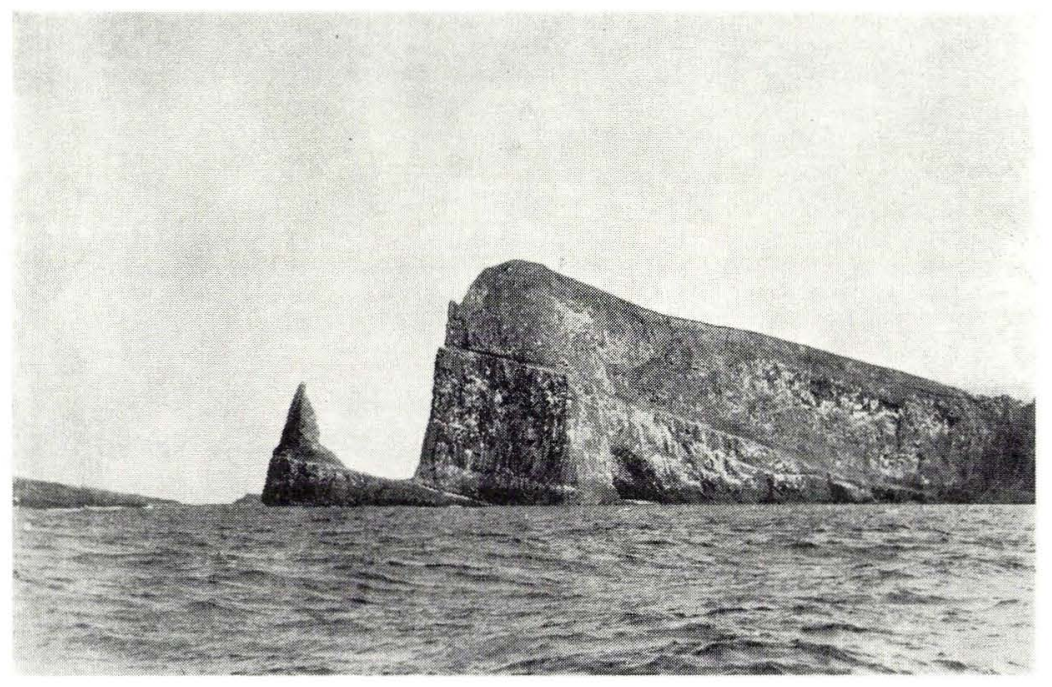

Fig. 12. West face of Mykineshólmur.

A tendency towards columnar jointing can be seen everywhere, most clearly in the skerries on the western end of the island; the flows also show rather prominent columnar structure in the cliff on the south side of the island at Barmur. Columnar structure is however best developed in Korkadalur, on the north side of the island; two prominent columnar-jointed flows can be seen one above the other at this locality. The columns reach a height of up to about $30 \mathrm{~m}$.

In the cliff on the south side of the island wedging-out of flows can be seen, e.g. south of Steinshellisgjógv, west of Tindskriðubarmur, on the east side of Smørbúshellisgjógv and at Barmur.

On Mykines the dip has been calculated as being about $13^{\circ} \mathrm{SE}$ around Hólmgjógv and about $8^{\circ}$ ESE on the eastern side of the island. In the westernmost part of Mykineshólmur a dip of about $20^{\circ}$ was observed (fig. 12).

Just as on Suðuroy the interbasaltic sediments often contain small amounts of coal.

On Mykineshólmur a sedimentary sequence occurs about $150 \mathrm{~m}$ west of the bridge over Hólmgjógv (fig. 13).

A sedimentary sequence in the highest part of Fjørudalsnev near the landing place on Mykines (Rasmussen 1947, 1951) was already well known in olden days. It has received mention because of its 


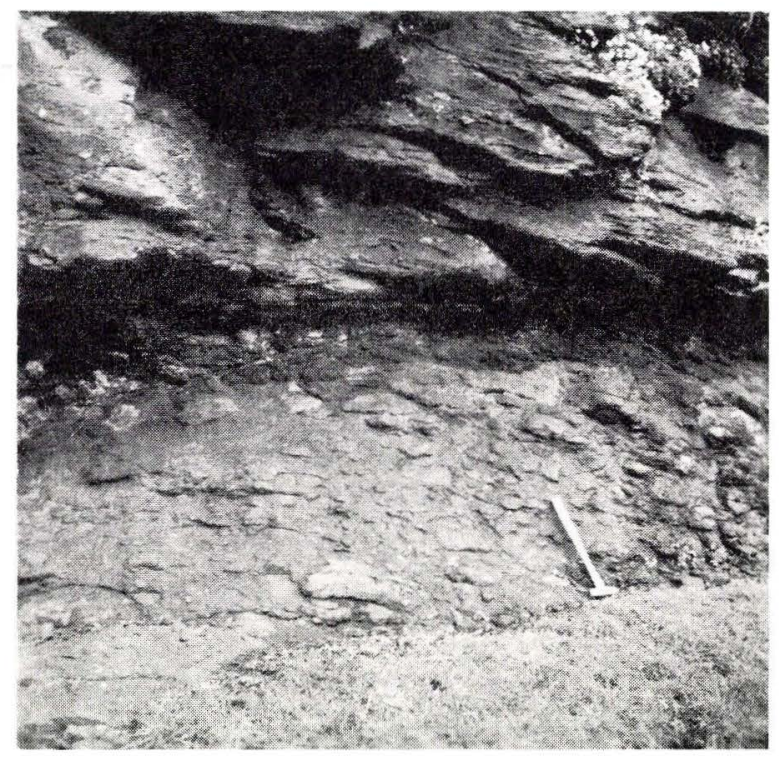

Fig. 13. The boundary between the upper and lower parts of the sedimentary beds at Hólmgjógv, Mykines.

fossil content, which includes indeterminable leaves (Hartz 1903, R. Rasmussen 1925) and of Metasequoia occidentalis (Rasmussen and Koch 1963).

On a ledge in the cliff on the south side of the island a coalbearing sedimentary sequence is present. It may be the same sequence that occurs below Ketilsheyggjur in the middle of the island and in Kálvadalur on the north-east side.

At Ketilsheyggjur in the middle of the island, at a height of about $370 \mathrm{~m}$, there used to be a small mine where people collected coal for household use. It has now collapsed and is overgrown, but digging can still yield dross and loose coal fragments.

\section{Gáshólmur}

Gáshólmur consists of four basalt flows, which belong to the lower basalt series. These are separated by three welded scoriaceous horizons. The second-highest flow, which rests on a tuff bed, shows the maximum thickness, $30-40 \mathrm{~m}$, while the others only have a thickness of about $10 \mathrm{~m}$ or somewhat less. 


\section{Tindhólmur}

On Tindhólmur there are also four flows belonging to the lower basalt series. It seems likely that the thick (second-highest) flow on Gáshólmur corresponds to the lowermost flow on Tindhólmur. Lavas from the lower basalt series are the only lavas found in the western and northern parts of the island. Towards the south and east these are overlain by the coal-bearing sequence, the tuff-agglomerate zone and flows belonging to the middle basalt series.

The surfaces of the lowermost basalt flow and of the flow above it show towards the west a fracture system striking at about $120^{\circ}$, i.e. approximately in the direction of dip. The same direction can also be seen in the clay bed above the second-lowest flow. Columnar structure is found, but is very irregular and is often only suggested.

The dip on the west side of the island is ESE, while on the east side it is almost SSE. This is due to a fault through Neytagjógv (strike of fault $125^{\circ}$ ) with a downthrow of about $4 \mathrm{~m}$ on the south-west side, and possibly also to later intrusion.

While the lowest three flows cut sea level on the island, the highest flow wedges out. The wedging-out can be seen in the innermost part of the bay at Hólmsmøl on the north-eastern side of the island and in the bay west of Júgur on the south side. Between this and the second-highest flow on this island a new, thinner flow appears, which wedges out towards the west above the middle of the beach west of Júgur and towards the east at the skerries east of Júgur (fig. 14). In the small skerries east of the island and along the edge of the beach on the eastern point of the island, basalt can be seen in places above sea level.

\section{Vágar}

Lavas belonging to the lower basalt series only occur in the westernmost part of Vágar, since the uppermost flows reach sea level along a line running from south of Álkuklettur to east of Víkar. The highest point reached can be found at Barðið, $278 \mathrm{~m}$ above sea level, and the dip is therefore $3^{\circ}$ towards ESE $\left(120^{\circ}\right)$. Lava flows belonging to the upper part of the lower basalt series can be seen in the mountainside between Gásadalur and Víkar; as on Tindhólmur they are overlain by the coal-bearing sequence, the 


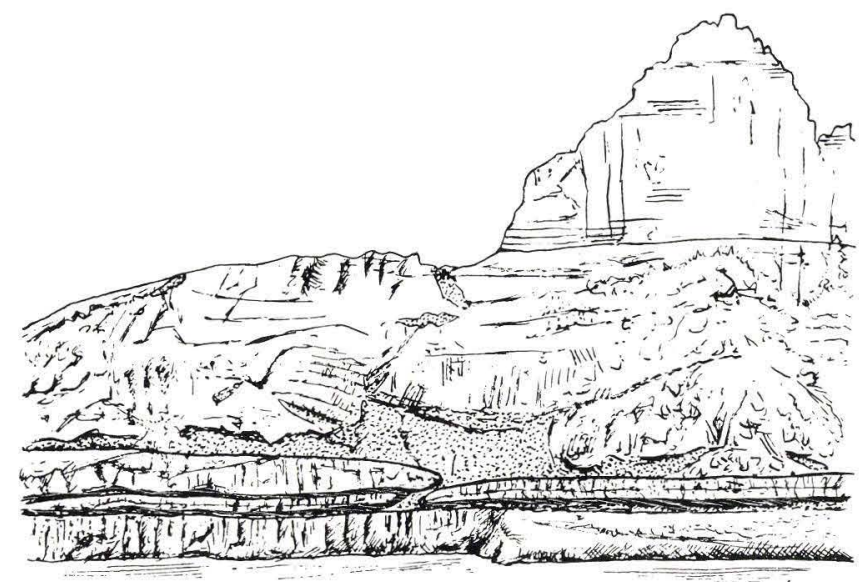

Fig. 14. Basalt flows wedging out on the south side of Tindhólmur.

beds of the tuff-agglomerate zone and the lavas of the middle basalt series.

All the way from Gásadalur to Víkar the interbasaltic tuffclay sediments can be seen; the top two beds are the thickest, about $10 \mathrm{~m}$. On Vágar also these sediments contain a little coal.

In the mountainside just west of the village of Gásadalur, about $60 \mathrm{~m}$ above sea level, a small amount of coal can be seen in a thick tuff-clay sequence about $10 \mathrm{~m}$ thick below the basalt flow that forms the base of the main coal-bearing sequence (fig. 15).

In the broad bay west of Víkar an only partially exposed sedimentary sequence occurs near the coast. It consists mainly of brown bedded clay with thin veins of clay-ironstone, which are about $1 \mathrm{~cm}$ thick. There are also some very thin seams of coal with a maximum thickness of about $1.5 \mathrm{~cm}$.

In the bay to the east of Víkar another sedimentary sequence reaches sea level. It is 3-4 m thick. It consists of bedded clay, mainly brown in colour, with thinner stripes of darker-brown clay and yellow and grey clay. In addition there are thin sinuous veins of clay-ironstone about $2 \mathrm{~cm}$ thick and thin seams of coal whose thickness ranges from less than $1 \mathrm{~cm}$ to $3 \mathrm{~cm}$.

The volcanic activity has been rhythmic in the sense that activity that has resulted in the formation of a lava flow has usually been followed by a shorter or longer period of quiescence. The volcanic material is mainly lava with subordinate agglomerates and tuffs. The 


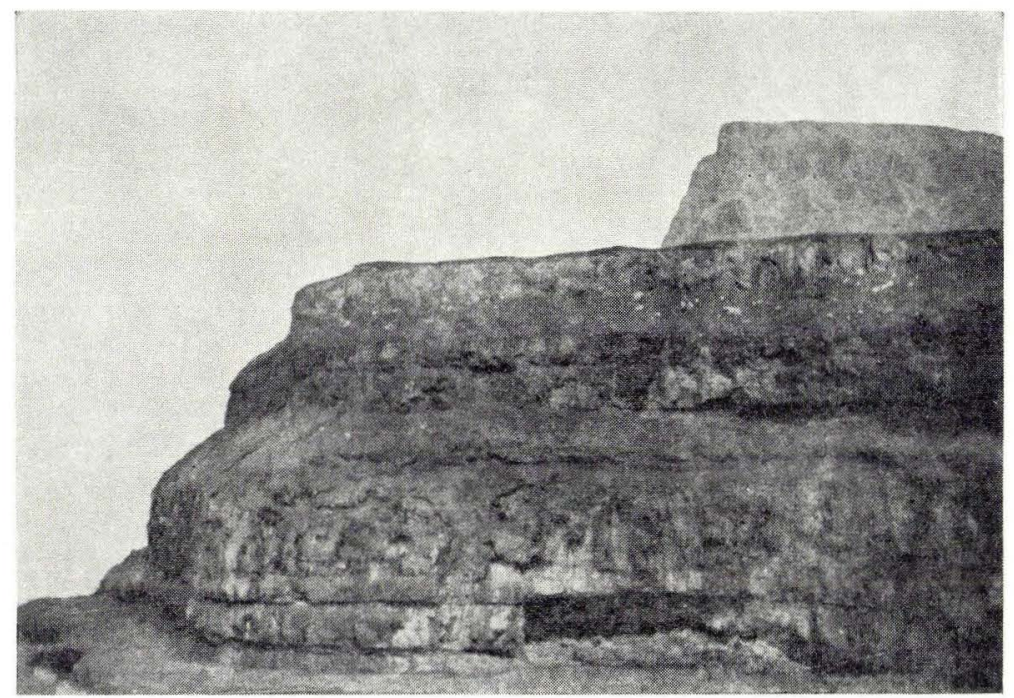

Fig. 15. The interbasaltic tuff-clay sediments just west of Gásadalur, Vágar.

period of quiescence marks a temporary cessation of volcanism and is expressed by subaerial weathering, erosion of the basalt surface, deposition of interbasaltic sediments and the incoming, or transport into the area, of vegetation, which can be seen from the presence of thin coal seams or lenses.

We have no direct evidence of the feeders for the lower series, but because of the considerable thickness of the flows and their wide areal extent we consider it to be probable that the eruption took place through fissures. The fissures probably had the same trend as the Wyville-Thompson Ridge and the Faeroese fjord system, since the tuff-agglomerate zone (p. 64), which may be presumed to be covering fissures and their immediate vicinity in both Sưuroy and Vágar, the only two places where observation is possible, occupy elongated areas several kilometres in length with NW-SE trend. A prominent group of lineaments in both the southern and central parts of Suðuroy have the same trend. The lineaments are wide and give rise to prominent topographic features; their main trend is NW-SE. Towards the north-west a prominent lineament with the same trend shows a downthrow of $10-11 \mathrm{~m}$ on its western side; this fault is older than the middle basalt series. The main trend of the dykes in Suðuroy, which follow the lineament system (see map), is also NW-SE. 


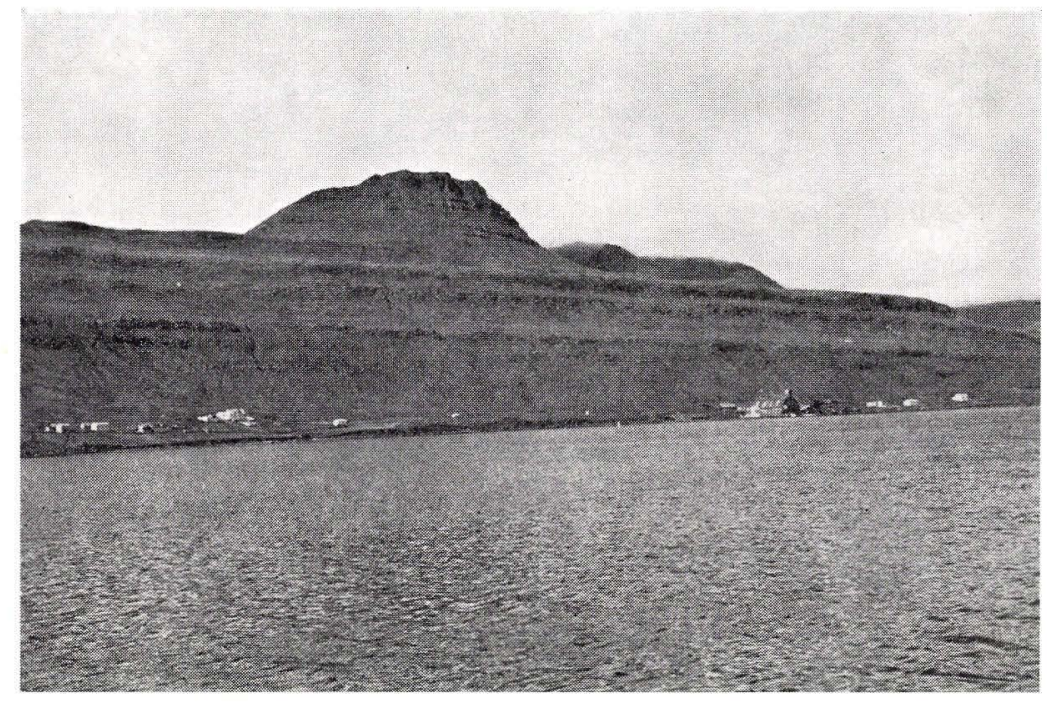

Fig. 16. Typical landscape with big steps in the lower basalt series. South side of Trongisvágur.

It should also be noted that the greatest thicknesses in individual flows have been measured towards the west at Fámjin $(50 \mathrm{~m})$ and Mykines $(70 \mathrm{~m})$, which may indicate that an active fissureeruption system lay not very far west of the present west coast of Suðuroy.

The dip in the lower basalt series can be seen from the geological map; it is eastwards in the south-eastern part of Suðuroy; farther north it becomes north-easterly and towards the north-west northerly. One almost has the impression of a dome formation or the existence of an anticlinal deposition with a weak northward plunge. Towards the north-east the overlying flows of the middle basalt series dip north-east and towards the north-west they dip northwest to north.

The transition from a north-east to a northwards dip is very difficult to see and does not provide a clear solution to the problem of whether or not there is an unconformity between the lower and the middle basalt series. The exceptionally thick tuff-agglomerate zone found in the north of Suðuroy (p. 65) and the large amount of younger intrusive basalts (p. 108) both in the coal-bearing sequence and in the zone above it have added to the problem. 
On the other hand, if we go from Suðuroy to Mykines-Vágar we find clear evidence of an unconformity. The strike in the lower basalt series in eastern Mykines and western Vágar is about the same, even if the dip in Mykines is somewhat steeper than in Vágar. If we go from west to east we can see that the lavas in the lower basalt series have another strike direction and at the same time the dip is more towards the east; the amount of dip is however about the same. This shows that there is an unconformity between the two sequences even if this is not particularly marked. One of the authors (J.R.) has had an opportunity of flying over Sørvágsfjørður and has seen clearly from the air an unconformity at the base of the middle basalt series in the area where the two basalt series are in direct contact. The unconformity is difficult to detect on the ground in the critical area because there have been strong disturbances caused by intrusive basalts. On the basis of our present knowledge we can however show that the unconformity at any rate is older than the middle basalt series; in other words before this series was formed there must have been a gentle tilting of the first-formed part of the plateau.

The building-up of the Faeroese plateau in its entirety is thus not the result of continuous volcanic activity; the break in the eruption clearly shown by the coal-bearing sequence was long enough for an isostatic adjustment to take place.

The aphyric and cryptophyric basalts of the lower series have a dark, almost black colour, sometimes with a bluish or dark-greenish tinge on fresh surfaces. In places where water has run downslope over the basalts they often have a rusty hue, whereas outcrops in grassland have a light-grey-weathering crust. In general the lavas are aphyric, fine- to medium-grained rocks with intergranular texture, but occasional tiny phenocrysts are visible on weathered surfaces. A small number of partly altered olivines and pseudomorphs of olivine occur at random.

Clinopyroxenes occur in various sizes from groundmass individuals through quasiphenocrysts to semiphenocrysts. All the semiphenocrysts are augites, extending into the field of ferroaugites. The groundmasses contain two clinopyroxenes, one augitic and the other pigeonitic. The maximum amount of pigeonite in any given lava is $10-12 \%$ by volume.

The quasiphenocrystic and semiphenocrystic plagioclases are gen- 
erally labradoritic, with an average of about $65 \%$ An. The composition of the groundmass plagioclases is about $60 \% \mathrm{An}$. In the lavas just under the coal-bearing sequence the plagioclases are often intensely altered and incipient formation of feather-shaped zeolitic material in them is not uncommon. This is probably due to percolation of surface water during a hiatus in the volcanic activity.

There are usually two generations of black ores, one consisting of larger, more or less euhedral grains, and the other of small, rounded grains in the groundmass. Some of the lavas of sections II a and II $\mathrm{b}$ contain conspicuous semiphenocrysts of ore.

Glass may constitute up to about $10 \%$ of the rock, the amount varying from flow to flow; its colour is generally brownish in various shades. Green alteration products occur widely, especially in profile section III, where they occur together with the altered plagioclases mentioned above.

The average mineral composition of the quartz tholeiitic, aphyric to cryptophyric lavas is:

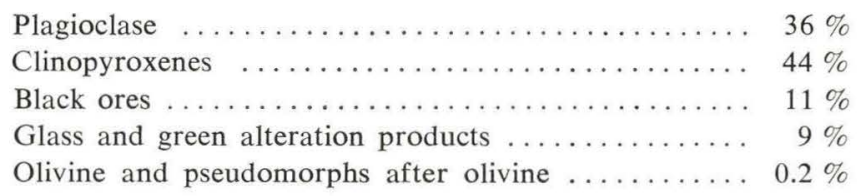

(Chemical analyses are given on p. 139 in the Memoir.) 


\section{The coal-bearing sequence}

After the formation of the approximately $900 \mathrm{~m}$ thick lower basalt series there was a fairly lengthy period of quiescence, during which there was some erosion of the flows and thereafter deposition of the sediments of the coal-bearing sequence (fig. 17).

The coal-bearing beds were deposited on the eroded and subaerially weathered surface of the lower basalt series; in places the beds rest on the highest flow and in places where this has been eroded away they rest on the second-highest flow. A good impression of the hummocky and uneven surface of the underlying basalt can be obtained where this has been washed clean by wave action where it meets sea level; it is particularly clearly exposed at Kolaratangi on the north-west side of Grímsfjall. Large bulges in the underlying basalt can also be seen in the coal mines, where they interfere with coal mining (fig. 19).

The coal-bearing sequence occurs on Suðuroy, Tindhólmur and Vágar. It is only on Sưuroy that coal occurs in sufficient quantities to permit it to be mined on any scale.

\section{Suðuroy}

The coal-bearing sequence here covers an area of about $23 \mathrm{~km}^{2}$. It can be seen in natural exposures in the mountainside on the west of the island, starting from the beach at Kolaratangi on the northwest side of Grimsfjall and climbing towards the south to the mountains south of Trongisvágur, where it is at its highest, about $425 \mathrm{~m}$ above sea level, at Knúkur, just south of the Fámjin mines. On the east side of the island the coal-bearing sequence can be seen on the beach at Froðbiarnípa between Hvannhagi and Lónin, and around Tjørnunes, on the south side of Hvalbiarfjørður. On the north side of Hvalbiarfjørður the sedimentary sequence reaches sea level in the innermost part of the bay, but here the coal seems to have thinned completely out. The deposits of the coal-bearing sequence thus cut through the mountains from Grimsfjall in the north-west to Hovstúgva in the south-east, interrupted 


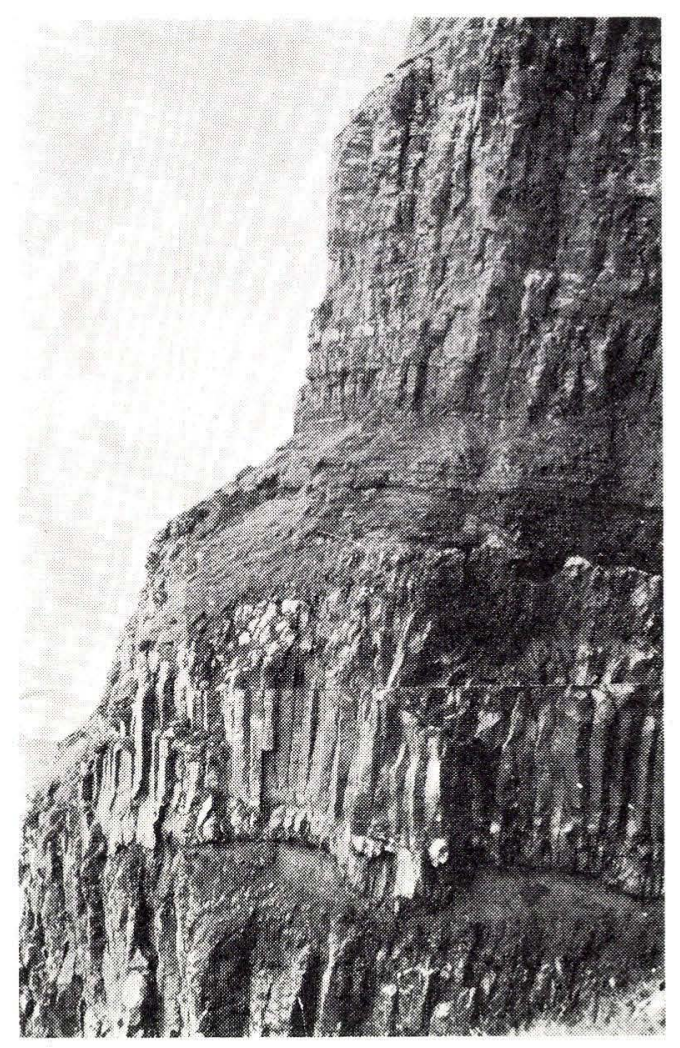

Fig. 17. Lower basalt series - coal-bearing sequence - middle basalt series in the mountain wall north of Geitaskoragjógv, Suðuroy.

by Hvalbiareið, the Trongisvágur valley and the area between Oyrnafjall and Kolheyggjur (fig. 18).

The total coal area can be divided into four separate coalfields:

\section{Grimsfjall.}

2. Northern coalfield (including the Hvalba mines).

3. Southern coalfield (including the Rangibotnur mines).

4. Kolheyggjur-Hovstúgva.

The thickness of the coal-bearing sequence is usually around $10 \mathrm{~m}$, with local variations. The coal usually occurs as two separate seams, and the typical succession is as follows. At the base there is a bed of light (whitish-grey) underclay, which is known as "bankin". Above 


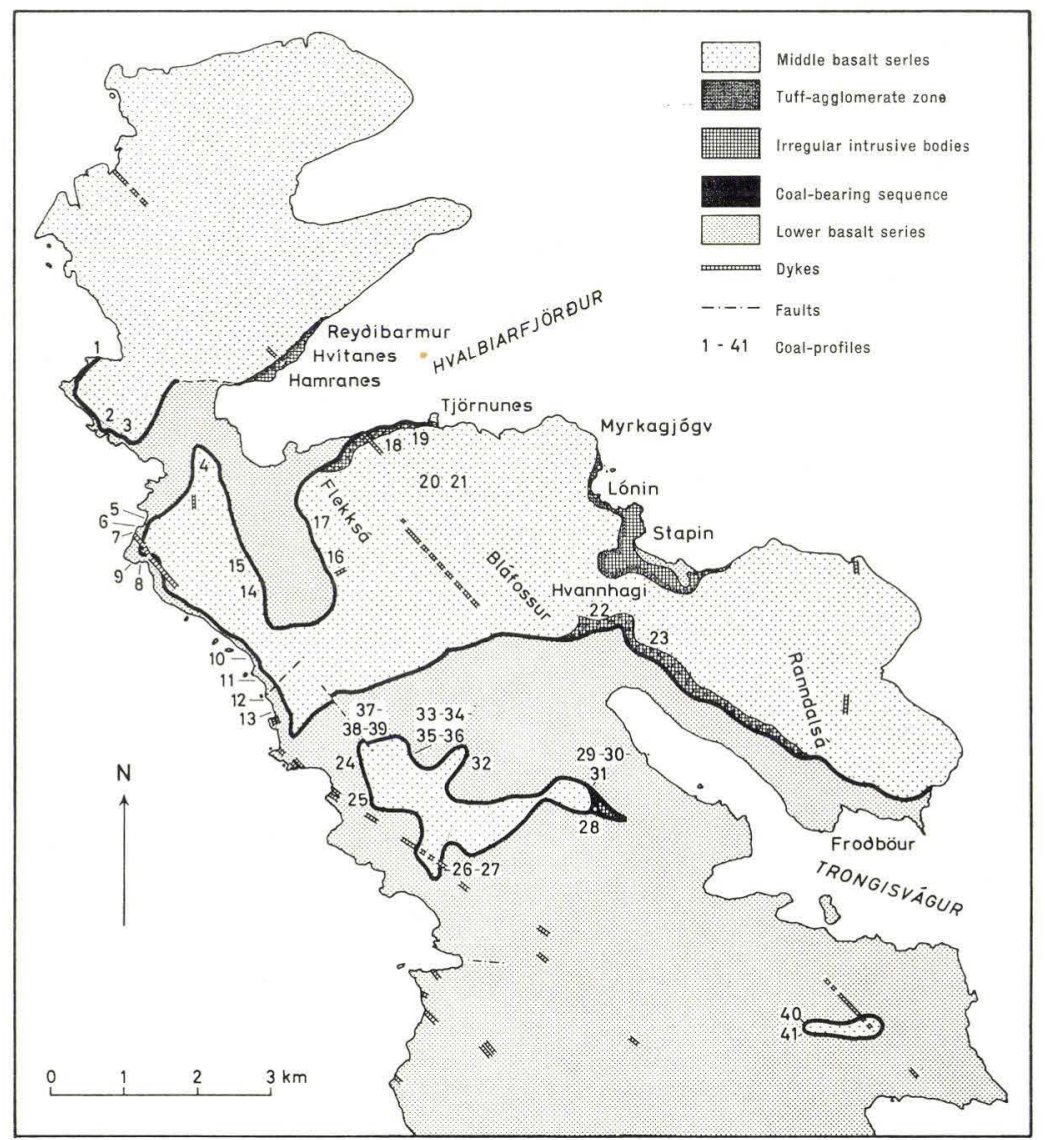

Fig. 18. Map of the area of outcrop of the coal-bearing sequence (black) on Suðuroy. Localities of profiles are indicated by Arabic numerals.

this is the lower coal seam, "stabbin", which is separated from the upper coal seam by a bed of dark shale, "rannin", which often contains thin streaks or lenses of coal. The upper coal seam is called "kolbandið"; it is overlain by a clay bed several metres thick, "fúrstin" (lower part), and "takleir" (upper part). Fluviatile conglomerates or "basaltic" sandstone sometimes take the place of or overlie this roof clay (Rasmussen 1952). In the lower part of the roof clay, "fúrstin", there are often small amounts of coal in the form of lenses or streaks, together with clay-ironstone and other concretionary material. The succession varies considerably, and there is some difference between the northern and the southern 
coalfields. In the northern coalfield "stabbin" is usually thicker than "kolbandið" while the opposite is the case in the southern coalfield. In the zone between the two coalfields it is not uncommon for there to be several coal seams, and in this area the succession as a whole is somewhat atypical.

\section{Grimsfjall. The coal-bearing sequence in Grímsfjall occupies} an area of $1.36 \mathrm{~km}^{2}$. It reaches sea level at Kolaratangi on the north-west side of Grímsfjall and presumably also at the old landing place in the bay at Hvalba, where however it seems to be greatly reduced in thickness.

At profile $1^{*}$ on Kolaratangi the underlying basalt is exposed; its surface has been washed clean by wave action and is uneven and strongly undulating. In the lower part of the roof clay, $4-4,5 \mathrm{~m}$, there are frequent thin lenses and streaks of coal whose thickness is a few centimetres or even less. In the upper part of the roof clay, which has a bluish appearance, there is no coal.

In profile 2 on the west side of Grímsfjall the roof clay is only $20 \mathrm{~cm}$ thick; its place is taken higher up in the profile by a conglomerate consisting of cobbles $(20 \mathrm{~cm})$ with well rounded components and above this by finer fluviatile material, which alternates with thin pebbly seams.

In profile 3, about $100 \mathrm{~m}$ south of profile 2, there is only a thin coal seam (coal with wood structure). Instead of the roof clay there occurs at this locality about $4 \mathrm{~m}$ fluviatile sand and gravel, in the lowermost $50 \mathrm{~cm}$ containing coal lenses, which are usually $1-3 \mathrm{~cm}$ thick. Along the east side of Grimsfjall the coal-bearing sequence is not exposed. The profiles described here and in the following pages comprise natural exposures, profiles exposed during test pitting and profiles based on measurements in older and newer coal mines.

2. Northern coalfield. In the northern coalfield the coal-bearing sequence occupies an area of $18.74 \mathrm{~km}^{2}$. For practical reasons, which will be given later, it will be appropriate to consider the northern coalfield as being composed of a western area of 11.00 $\mathrm{km}^{2}$ and an eastern area of $7.74 \mathrm{~km}^{2}$. The sequence is at its highest in the south-west and reaches sea level at Froðbiarnípa and at Tjørnunes.

In profile 4 in $\emptyset \mathrm{kslin}$ at the northern end of Prestfjall only $870 \mathrm{~cm}$ of brown clay was found, which locally is more greyish or dark. No coal was observed in the profile. Along the north-west side of Prestfjall the coal is not exposed, but at a single locality the lower boundary of the coal-bearing sequence was exposed during test pitting. According to reports from men

* Profiles: See plate 1. 
who have worked in the old, now-collapsed mines on the north-west side of Prestfjall, there is a coarse conglomeratic deposit instead of - or overlying - the roof clay.

Of the profiles 5, 6 and 7 Undir Bergsleiti, profile 5 was measured in the bottom of an old, still-open mine $(26 \mathrm{~m}$ in). The mine lies just back from a vertical cliff of about $135 \mathrm{~m}$ facing the sea, and is only $3 \mathrm{~m}$ from the edge of the cliff. Profile 6 was measured just north of the entrance to the mine and profile $737 \mathrm{~m}$ south of the entrance. In both profile 5 and profile 6 conglomerate occurs in the upper part of the profile instead of roof clay; in profile 6 it is $280 \mathrm{~cm}$ thick and the upper part contains coal lenses. The size of the components of the conglomerates varies. At about the middle of the sequence there is a band of much finer material, whose position in the sequence is as shown in the following profile, measured from the base up: $120 \mathrm{~cm}$ conglomerate, $30 \mathrm{~cm}$ finer material, $130 \mathrm{~cm}$ conglomerate. In profile 7 no conglomerate was found, but normal dark-brownish, sometimes lighter, clay. In addition to the frequently occurring thin coal streaks in the lower part of this clay there is also an interval of about $50 \mathrm{~cm}$ with alternating thin coal seams and clay in the upper part of the roof clay. While the whole of the coal-bearing sequence in profile 6 only had a total thickness of $395 \mathrm{~cm}$, it was found to reach $920 \mathrm{~cm}$ in profile 7 only $37 \mathrm{~m}$ to the south.

Profiles 8 and 9 were measured $1 / 2 \mathrm{~km}$ to the south, Suðuri undir Hæli; profile 8 , was measured in an old, now-collapsed mine and profile 9 about $45 \mathrm{~m}$ west of this. In profile 8 the depositional conditions are normal; in this profile, at the boundary between the roof clay and the overlying basalt, a coalified tree root was found. In profile 9 the upper coal scam ("kolbandið") is lacking. The lowermost $175 \mathrm{~cm}$, which consists of grey-brown, dark clay in this profile, contains as usual thin coal lenses; the uppermost $715 \mathrm{~cm}$ consists of brown clay.

Along most of the western cliff the coal-bearing sequence forms a ledge, Prestskorar and Geitaskor. It is sometimes exposed and it is sometimes hidden below the luxuriant vegetation. Both profile 10, north of Skarvgjógv, and profile 11, south of Skarvgjógv, show somewhat atypical depositional conditions.

In profile 10 the $12 \mathrm{~cm}$ thick light underclay is overlain by $70 \mathrm{~cm}$ brown clay and above this there is $16 \mathrm{~cm}$ brown clay, which contains disseminated coal. In profile $1136 \mathrm{~cm}$ underclay is overlain by $30 \mathrm{~cm}$ black clay with varying amounts of silt, containing thin coal seams in its uppermost part; above this is $10 \mathrm{~cm}$ coal with wood structure (coalified stems); this is overlain by $30 \mathrm{~cm}$ dark clay. The coal lenses in the lower part of the clay exceptionally reach $10 \mathrm{~cm}$ in thickness. In the whole of the area to the north where the sequence is exposed coalified fragments of tree trunks and other wood occur, but the beds disappear under vegetation before Skarvgjógv is reached.

In profile 12, north of Geitaskoragjógv, we find just as in the southern area that the upper coal seam has a greater thickness than the lower. In addition to the usual thin coal streaks in the lower part of the clay a thin coal seam of about $10-20 \mathrm{~cm}$ can be seen about $2.5 \mathrm{~m}$ above the upper 


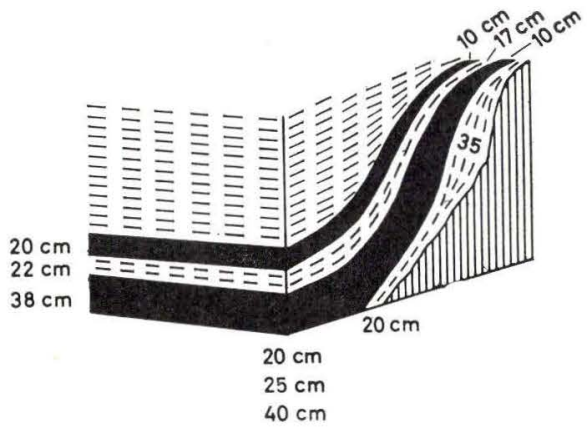

Fig. 19. Bulge in the surface of the underlying basalt near profile 14 .

main coal seam. At the top of the clay, between 8 and $9 \mathrm{~m}$ up in the profile,there is a bluish-black clay, which can be followed for a considerable distance to the north. This bed has often earlier been confused with coal.

Profile 13 was measured in an old, now-collapsed mine only $7 \mathrm{~m}$ long, situated about $1 / 2 \mathrm{~km}$ south of Geitaskoragjógv. The lowar coal seam here goes right down to the floor of the mine, so the underclay is not visible. Coalified wood can be seen in the lower part of the lower coal seam and in the clay above there is a coal lens or coal seam of $30 \mathrm{~cm}$.

Along the east side of Prestfjall there is a long row of mines, some of which are still open. The oldest of these were started as early as the 1780 s.

Profiles 14 and 15 are both representative and typical of this area; however, it can be noted that the coal thickness in the mine area is somewhat variable and not uncommonly somewhat less than in these two profiles. Fig. 19 shows the form of the coal seams where they overlie a $2 \mathrm{~m}$ high bulge in the surface of the underlying basalt near profile 14 .

The coals seem to have thinned out in the northernmost part of Prestfjall. In a mine about $1 / 2 \mathrm{~km}$ south of profile 4 only thin lenses of coal were observed.

On the east side of the valley south of Hvalba profiles 16 and 17 were uncovered during test pitting. While profile 16 shows typical depositional conditions and a considerable thickness of coal $(90 \mathrm{~cm})$, profile 17 , which in common with profile 16 was not dug clean throughout the whole of its length, shows atypical depositional conditions, since there is only a coal seam of $25-30 \mathrm{~cm}$ and above this $135 \mathrm{~cm}$ conglomerate (corresponding to the height of the test pit).

We have included in the eastern area the area east of the continuation of Trongisvágur valley, i.e. east of the westernmost limit of the tuff-agglomerates (see fig. 18). The coals in this area have thinned out considerably, and often do not form an unbroken coal seam. The depositional conditions have on the whole varied very much and the profiles vary considerably from place to place. Since the sequence in addition has been affected by subsequent explosive volcanism and moreover not uncommonly has been broken up by later intrusion, it is unlikely that the area in the future will be of any real significance for coal mining (Rasmussen 1952). 
Along the south side of Hvalbiarfjørour the depositional conditions vary and are usually abnormal and somewhat unpredictable. Profiles 18 and 19 , both of which were measured close to the beach, are therefore only correct for the line of profile. In profile 18, east of Seiðagjógv, the figures given are only approximate, since the individual beds are very irregular in thickness. Profile 19, west of Tjørnunes, was exposed during test pitting. In the line of profile itself the roof clay is arched up and measures $13 \mathrm{~m}$, while the roof clay immediately to the east of the profile only measures $6 \mathrm{~m}$. The coal-bearing beds round Tjørnunes are intruded by basalt; towards the west the base of the basalt is in contact with the roof clay.

In the Vatnsdalur valley south of Tjørnunes the coal-bearing sequence is partly exposed, the uppermost part of the roof clay being exposed below the waterfall in the stream Vatnsdalsá.

Profiles 20 and 21 came to light during test pitting and drilling below.

In profile 20, west of the stream, the roof clay was dug clean to a depth of $5 \mathrm{~m}$; this section was extended by drilling below to give the profile shown. In profile 21, east of the stream, the roof clay was dug clean to a depth of 8 $\mathrm{m}$, and drilling was undertaken to a depth of $2.80 \mathrm{~m}$ below this. It is unlikely that this profile reaches the base, and the thin $5 \mathrm{~cm}$ coal seam is probably only a coal lens in the upper part of the roof clay.

It is undoubtedly the coal-bearing sequence that can be seen again along the beach in the small bay Lónin, on the north-east side of Suouroy. The underlying flow here is very uneven and hummocky, and the beds are strongly dislocated and affected by later intrusions. Locally, north of Svínadalsá, the flow can be seen to be overlain by tuff-agglomerates, and locally, south of Svínadalsá, "basaltic" sandstone can be seen with coal lenses in the upper part. The coals are thin, only a few centimetres, and usually occur as lenses.

On the north side of the bay at Hvannhagi remains of the coal-bearing sequence are to be found as inclusions in intrusive basalt. Along the southeast side of the bay the coal-bearing beds can be seen near the coast (10$15 \mathrm{~m}$ above sea level); they are strongly dislocated and intrusive basalt lies on top of them.

Along the north side of Trongisvágur there are no natural exposures of the coal-bearing sequence, but it was accessible for measurement in some trial mines, which were abandonded long ago, at Botnsskarð, at Myllá, at $\emptyset \mathrm{kslin}$ and at the streams above the village of Froðba.

Profile 22, Myllá, and profiles $23 \mathrm{~A}$ and $23 \mathrm{~B}$, Økslin, were measured in old, abandonded trial mines. None of the profiles are typical. In profile 22 only the lowermost $50 \mathrm{~cm}$ consists of pure coal, while the overlying 40-50 $\mathrm{cm}$ consists of coal mixed with clay and alternating clay and coal seams. Profile $23 \mathrm{~A}$ was measured outside the mine. It shows $70 \mathrm{~cm}$ of coal mixed with clay, succeeded upwards by intrusive basalt. Profile $23 \mathrm{~B}$ was measured $7 \mathrm{~m}$ inside the mine, and shows $36 \mathrm{~cm}$ pure coal and above this $100 \mathrm{~cm}$ alternating clay and coal seams.

The coal-bearing sequence reaches sea level at Froðbiarnípa. The upper part of the sequence is exposed in the steep cliff; the lower part is covered by scree. There do not appear to be any unbroken coal seams. 
3. Southern coalfield. The southern coalfield is situated south-west of Trongisvágur and occupies an area of $2.60 \mathrm{~km}^{2}$. In their main features, typical profiles in the northern and southern coalfields correspond to each other. As already mentioned, however, the upper coal seam ("kolbandið") is thinner in the northern coalfield, while in the southern coalfield it is usually the lower coal seam that is thinner. The underclay in the southern coalfield usually has a grey colour, while in the northern coalfield it is often lighter. In the southern coalfield the shale zone that separates the two coal seams ("rannin") often contains a considerable amount of good coal in the form of coal lenses - bright coal ("nýrakol"); in the northern coalfield the lower part of the roof clay usually contains scattered thin coal streaks.

Profile 24, northern Rossarók, and profile 25, southern Rossarók, were uncovered while the whole sequence was being dug clean. Both show the typical succession for the area. In profile 24 there is a bed $(20 \mathrm{~cm})$ of greyblack clay between the underclay and the lower coal seam. This is very common in the area. In both profiles the shale that separates the two coal seams "rannin" contains coal; profile 24 shows: $10 \mathrm{~cm}$ clay, $21 \mathrm{~cm}$ coal, $5 \mathrm{~cm}$ clay; profile 25 shows: $10 \mathrm{~cm}$ clay, $16 \mathrm{~cm}$ coal and $4 \mathrm{~cm}$ clay. In both profiles the lower part of the roof clay contains scattered thin coal streaks.

Profile 26 was measured about $50 \mathrm{~m}$ inside the westernmost of the Fámjin mines; profile 27 was measured only about $25 \mathrm{~m}$ inside the same mine. In profile 27 the lower coal seam was not completely uncovered.

In the terrain just east of Oyrnafjall the coal-bearing sequence, which is thin here, is overlain by intrusive basalt. In the depression between Oyrnafjall and the intrusive basalt east of Oyrnafjall the coal-bearing beds have been exposed by erosion and the upper part of the roof clay forms the land surface. Towards the south a single, small isolated remnant of the lavas of the middle basalt series can be seen above the roof clay.

On the north side of the intrusive basalt only a little of the coal-bearing sequence can be seen, but on the south side it was exposed by cleaning up an old face (profile 28).

Profiles 29, 30 and 31 stem from an old mine gallery only $15 \mathrm{~m}$ in length with a few very short side galleries, on the north-east side of Oyrnafjall. The beds vary considerably in thickness; they are dislocated, sinuous and sometimes strongly squeezed by intrusive basalt, which occurs in the roof inside the mine and above the mine entrance.

In profile 32 on the north-east side of Mót the thickness of the coalbearing sequence is only about $3 \mathrm{~m}$. The underlying basalt at this locality is sinuous and greyish-weathering on the surface; underclay is lacking. "Rannin" contains $10 \mathrm{~cm}$ coal. Above the roof clay is a conglomeratic fluviatile deposit $50 \mathrm{~cm}$ thick. A test pit on the east side of Mót farther into Hvammabotnur showed no coal, only clay. The sequence was very thin here also. 
Profiles 33, 34, 35 and 36 were measured inside a producing mine in Rangibotnur. They do not show the total thickness of the sequence, since they only reach up to the roof of the mine.

In profile 33, at about the middle of the underclay, a lens of coal with wood structure, measuring $7 \times 80 \mathrm{~cm}$, can be seen. Coal with wood structure is in general rather common below the lower coal seam in this area. In profile 34 the lower coal seam is split in the middle by a thin clay bed. This sometimes happens at other localities.

As already mentioned the surface of the underlying basalt is often uneven and hummocky. Profile 36 was measured in the middle of one of these hummocks, which was $16.5 \mathrm{~m}$ in length.

Profiles 37, 38 and 39 were measured inside a now-abandonded coal mine south-east of Botnsskaro (Gudmund's mine). About $60 \mathrm{~m}$ east of this mine a fault with an approximately NW-SE trend can be seen; it has a downthrow to the south-west of about $10 \mathrm{~m}$. Inside the coal mine the fault forms a flexure in the eastern side gallery. Above, in the middle of the basalt series, only a weak lineament can be seen, but no fault. The fault can be followed towards the south-east; east of the Fámjin mines the downthrow to the south-west is $11 \mathrm{~m}$; towards the north-west the downthrow decreases, and at Hvalbiareio it is only about $1 \mathrm{~m}$.

4. Kolheyggjur-Hovstúgva. This coalfield, which lies between the villages of Øravík and Hov, occupies an area of only $0.24 \mathrm{~km}^{2}$. Towards the west, in Kolheyggjur, the lower boundary of the coalbearing sequence is situated at about $400 \mathrm{~m}$ above sea level, and towards the east, in Hovstúgva, it is about $310 \mathrm{~m}$ above sea level.

At the western end of Kolheyggjur, where there has been trial digging for coal, the coal-bearing sequence has been partially exposed for a distance of about $70 \mathrm{~m}$. Profiles 40 and 41 were measured here with $6 \mathrm{~m}$ between them. While profile 41 , the southern profile, shows the normal succession, profile 40 , the northern profile, is atypical, since there is only one coal seam (the lower) and just above this roof clay with scattered coal. The total thickness of the succession varies from 3 to $4 \mathrm{~m}$.

On the eastern side of Hovstúgva a 4-5 m thick brownish and sometimes lighter-greyish clay zone was exposed by test pitting. In the lowermost part of this clay thin coal seams with a thickness of $1-5 \mathrm{~cm}$ were found.

The coal is at any rate in part allochthonous coal, since the vegetation which formed the source material for coal formation did not stem from material growing in the area itself, but from remains of trees transported to the area from areas round about. This material was deposited in a basin on an old, highly weathered and eroded surface; this can be seen, for example, from the fact that the 
underclay on which the coal rests is very hummocky and the coal seams vary considerably in thickness. The coarse conglomerates with their inclusions of stem and branch fragments on each side of Hvalbiareið may point to the presence of an old river channel here.

In general it can be said that the thickness of the coal is greatest towards the south-west and that it is reduced towards both the north and the east.

In the whole of the western coal area the coal-bearing sequence is almost undisturbed; there are only a few dykes and faults here, with the exception of the NW-SE trending fault in Gudmund's mine mentioned earlier; usually the faults are so small that they rarely cause any real trouble during coal mining. In the eastern area the beds are however, as mentioned earlier, highly disturbed, dislocated and locally disintegrated by explosive eruption and later intrusion.

In both the western mountain wall and in the coal mine on the east side there are coalified stem and branch fragments; these are most common between the underclay and the lower coal seam, but are also present higher up in the profile. They can sometimes be seen in the roof clay and often, as already mentioned, in the fluviatile conglomerates, which locally, e.g. at Hvalbiareið, are overlain by or take the place of the roof clay. In the description of profile 8 , Suðuri undir Hæli, a coalified tree root was stated to occur at the boundary between the roof clay and the overlying basalt. Similar root fragments have also been found in the coal mines. Unfortunately a more precise determination of these stem, branch and root fragments has not been possible up till now. Leaf impressions seem to be a very rare occurrence.

While macrofossil material has not been able to provide a basis for an age determination of the coal seams, microfossils (spores and pollen) indicate an Eocene age (Laufeld 1965).

The Faeroese coal lies in the boundary area between lignite and bituminous coal. With reference to appearance and quality we distinguish between two types: bright coal (vitrain) and dull coal (durain). The bright coals are shiny, have a conchoidal fracture, are very pure and are fairly resistant to weathering. They are usually found as lenses or kidney-shaped bodies (hence the Faeroese name "nýrakol"). The dull coals are often striped (alternating bands of vitrain and durain), are not as pure as the bright coals, 
and are soft and disintegrate readily when they lie exposed to the air. It is difficult to express the relative amounts of the two coal types even approximately, but at any rate it can be said that the bright coals occur in much smaller amounts than the dull coals. The bright coals usually occur in the upper coal seam; the coals in the lower coal seam are usually dull, striped coal. The coal that occasionally, particularly in the southern coalfield, occurs in "rannin" (the clay zone that separates the lower and upper coal seams) is usually bright coal. The calorific value of the bright coals is about $6,000 \mathrm{Kcal}$. and that of the dull coals is usually 4-5,000 Kcal. The ash content of the bright coals is low, under $5 \%$, while the ash content of the dull coals is considerably higher, often up to $20 \%$ and occasionally even higher.

\begin{tabular}{|c|c|c|c|c|c|c|c|c|}
\hline \multirow[b]{3}{*}{ Coalfield Locality } & \multicolumn{3}{|c|}{ Caloric value } & & \multirow{2}{*}{\multicolumn{2}{|c|}{ Sulphur \% }} & \multirow{2}{*}{\multicolumn{2}{|c|}{ Moisture \% }} \\
\hline & & $\mathrm{l} / \mathrm{kg}$ & & & & & & \\
\hline & $\begin{array}{c}\text { Bright } \\
\text { coal }\end{array}$ & $\begin{array}{l}\text { Dull } \\
\text { coal }\end{array}$ & $\begin{array}{l}\text { Bright } \\
\text { coal }\end{array}$ & $\begin{array}{l}\text { Dull } \\
\text { coal }\end{array}$ & $\begin{array}{l}\text { Bright } \\
\text { coal }\end{array}$ & $\begin{array}{l}\text { Dull } \\
\text { coal }\end{array}$ & $\begin{array}{l}\text { Bright } \\
\text { coal }\end{array}$ & $\begin{array}{l}\text { Dull } \\
\text { coal }\end{array}$ \\
\hline 1. Southern Rangibotnur ... & 5,886 & & 2.77 & & 0.74 & & 12.50 & \\
\hline 2. Southern Rangibotnur ... & & 4,025 & & 29.50 & & 1.10 & & 12.00 \\
\hline 3. Southern Rangibotnur ... & 5,763 & & 3.36 & & 0.78 & & 11.60 & \\
\hline 4. Southern Rangibotnur ... & & 3,152 & & 42.70 & & 0.80 & & 10.00 \\
\hline 5. Northern Prestfjall . . . . . . & 6,125 & & 1.12 & & 0.54 & & 11.30 & \\
\hline 6. Northern Prestfjall . . . . . & & 5,086 & & 16.20 & & 1.24 & & 10.00 \\
\hline
\end{tabular}

From time to time and according to whether interest in the economic working of the coal occurrences has been on the increase or decrease, the coal reserves have been subjected to various evaluations. See, for example, Landt (1800), Henchel (1778), Kabell (1851), " Johnstrup (1873), Stokes (1874), Helland (1880), Ussing (1902), Bergh (1905), Les Gisements de Houille de Suderö (1908), Nielsen (1933), Humlum (1943) and Marstrander (1950). The evaluations range from very realistic figures to purely wishful thinking. An evaluation on the basis of mapping of the coal-bearing sequence in Suðuroy in the years 1952-54 and a critical investigation of earlier information can be found in Rasmus$\operatorname{sen}(1958,1959)$.

On the basis of the coal areas delimited in the years 1952-54

* Report to the Ministry of Home Affairs, 3 January 1851, with reference to Professor Forchhammer, 26 May 1840. 
the amount of extractable coal present in the whole of the western area should be as in the following:

1. Grímsfjall

$\left.\begin{array}{ll}\text { area } & 1.36 \mathrm{~km}^{2} \\ \text { sp. gr. } & 1.35 \\ \text { thickness } & 19 \mathrm{~cm}\end{array}\right\}$

348,840 tons

2. Northern coalfield

$\left.\begin{array}{ll}\begin{array}{l}\text { area } \\ \text { sp. gr. }\end{array} & \begin{array}{l}11.00 \mathrm{~km}^{2} \\ \text { thickness }\end{array} \\ 72 \mathrm{~cm}\end{array}\right\} 10,692,000$ tons

3. Southern coalfield

$\left.\begin{array}{ll}\text { area } & 2.60 \mathrm{~km}^{2} \\ \text { sp. gr. } & 1.35 \\ \text { thickness } & 79 \mathrm{~cm}\end{array}\right\}$

$2,772,900$ tons

4. Kolheyggjur-Hovstúgva

$\left.\begin{array}{ll}\text { area } & 0.24 \mathrm{~km}^{2} \\ \text { sp. gr. } & 1.35 \\ \text { thickness } & 25 \mathrm{~cm}\end{array}\right\}$

81,000 tons

$13,894,740$ tons

About 2 mill. tons of the total 14 mill. tons must be considered to have been mined already or to be closed in by abandoned and collapsed mines so that future mining is not possible. There remain about 12 mill. tons, which must be considered to be the total amount of coal workable.

Since it is unlikely that the two small areas Grímsfjall and Kolheyggjur will ever have any practical significance the reserves are reduced by about $1 / 2$ mill. tons. In addition it should be pointed out that experience in the past and more recently has shown that the conditions for mining in the Oyrnafjall area must be described as unfavourable because of the depositional conditions, and that during mining a certain loss of the total amount must be counted on.

Because of reasons given earlier no real calculation of the amount of coal in the eastern area can be made, and it would therefore not be reasonable to include this area in an evaluation of mineable coal. The area amounts to $7.74 \mathrm{~km}^{2}$, and the specific gravity of the coal is 1.35; if the average thickness is put at about $40 \mathrm{~cm}$ or

** The average thickness in the four coalfields is estimated to be: Grímsfjall $19 \mathrm{~cm}$, northern coalfield $72 \mathrm{~cm}$, southern coalfield $79 \mathrm{~cm}$ and Kolheyggjur-Hovstúga $25 \mathrm{~cm}$. The figures are based on measured and specially selected profiles totalling 4,20,15 and 3 respectively. The specific gravity 1.35 is calculated on the average of 10 determinations. 
somewhat less, the reserves here should be roughly 5 mill. tons, but mining here will, as mentioned, encounter quite irregular bedding and this will result in the overhead costs being very high.

In any future coal mining in Sưuroy the maximum coal reserves that can be expected are 10-12 mill. tons.

The reason that there are often such differences between earlier evaluations of the coal reserves in Suðuroy and the results that have now been obtained are: 1. Many previous estimates of the coal areas have been too large because when the limits of these areas were being drawn some of the locally occurring coal-bearing beds belonging to a lower level were included. 2. The average thickness was often overestimated. 3 . The beds thin out markedly towards the north and east and therefore have a considerably lower average thickness in the north-eastern area; this fact was not fully understood and therefore insufficient attention was paid to it. 4. In the evaluation of the coal reserves more mineable coal seams have been counted on than there actually are.

\section{Tindhólmur}

The coals on Tindhólmur do not form a continuous seam. They occur widely scattered as thin streaks, lenses or eyes. The sequence is highly disturbed and in general difficult to understand.

\section{Vágar}

The coal-bearing sequence occupies the westernmost part of Vágar, west of the line Álkuklettur to east of Víkar, where it reaches sea level. The sequence is at its highest at Barðið (south of Gilið á Dýpinum), $278 \mathrm{~m}$ above sea level. The only place where the coals have any thickness worth speaking of is in Hellisgjógv, where the total coal thickness is about $90 \mathrm{~cm}$; however this includes several continuous clay beds, so there is no pure coal seam thicker than about $10 \mathrm{~cm}$. Light underclay can be glimpsed in places. The coals thin out considerably towards the east and usually only occur sporadically farther east. Looking towards Hellisgjógv the cliff profile is built up as follows, from the base upwards: 1. basalt flows of considerable thickness with scoriaceous zones and tuff (lower basalt series), 2. clayey sediments (coal-bearing sequence) and 3 . 
thin lava flows with vesicular zones in between (middle basalt series), a profile that is completely identical with the profile in the mountain wall on the north-west side of Suðuroy.

Between Hellisgjógv and Barðið the coal-bearing sequence seems to be undisturbed and to have a generally regular course. In the area from Barđio (south of Gilið á Dýpinum) to a short distance south of Streymnes quite insignificant coal occurences can be seen locally. The whole sequence in this interval is overlain by tuff-agglomerates just as to the south in Bíggjarurð, south of the village of Gásadalur, and is dislocated, with abnormal bedding (see pp. 70, 113).

Along the line from Hellisgjógv to Víkar, on the north side of the island, the coal-bearing sequence is only locally exposed. West of Hjallabølsflesjar its lower boundary is about $220 \mathrm{~m}$ above sea level. At this locality a fluviatile conglomerate $2-3 \mathrm{~m}$ in thickness forms a part of the sequence.

\begin{tabular}{|c|c|c|c|c|c|c|c|}
\hline \multirow[b]{2}{*}{ Coalfield Locality } & \multicolumn{4}{|c|}{ Calorific value } & & \\
\hline & $\begin{array}{l}\text { Kca } \\
\text { Bright } \\
\text { coal }\end{array}$ & $\begin{array}{l}1 / \mathrm{kg} \\
\text { Dull } \\
\text { coal }\end{array}$ & $\begin{array}{l}\text { Ash } \\
\text { Bright } \\
\text { coal }\end{array}$ & $\begin{array}{l}\% \\
\text { Dull } \\
\text { coal }\end{array}$ & \begin{tabular}{cc}
\multicolumn{2}{c}{ Sulphur \% } \\
Bright & Dull \\
coal & coal
\end{tabular} & $\begin{array}{c}\text { Mois } \\
\text { Bright } \\
\text { coal }\end{array}$ & $\begin{array}{l}\text { ure \% } \\
\text { Dull } \\
\text { coal }\end{array}$ \\
\hline Vágar Hellisgjógv & 6,268 & & 3.00 & & & 8.10 & \\
\hline Vágar at Rættargarð ..... . & & 4,377 & & 8.70 & & & 13. \\
\hline
\end{tabular}




\section{The tuff-agglomerate zone}

After the lower basalt series had been laid down and after the subsequent rather lengthy period of quiescence with deposition of the coal-bearing beds, the volcanic activity started again with a highly explosive initial phase, during which it was almost exclusively loose eruptive products that were produced: volcanic bombs, lapilli and ash. These deposits of loose eruptive products, which lie between the coal-bearing sequence and the lowest lavas of the middle basalt series are termed by us the tuff-agglomerate zone.

During the explosive phase the coal-bearing sequence was shattered and the eruptive products were deposited above the coalbearing beds in the vicinity of the sites of the eruptions. Deposition of such inhomogeneous material as that which is produced by explosive volcanism will naturally have the character of a piling-up, and the thickness will therefore vary greatly from place to place. Since the tuff-agglomerates are moreover frequently overlain and penetrated by intrusive basalts (see p. 108) it will be very difficult if these rocks are not found completely exposed to assess their true thickness, even if both the lower and upper boundaries can be recognized.

Because of the north-east dip on Suðuroy and the south-east dip on Vágar the boundary between the coal-bearing sequence and the middle basalt series cuts sea level already on the north-eastern side of Suðuroy and the western part of Vágar; the tuff-agglomerate zone therefore only occurs above sea level west of these lines of intersection. The deposits of the tuff-agglomerate zone, which as mentioned must be presumed to be covering large fissures and their immediate vicinity, occupy elongated, approximately NW-SE trending areas on the north side of Suðuroy along Suðuroyarfjørður, on the west side of Vágar and on Tindhólmur along Mykinesfjørður and Sørvágsfjørður, a direction corresponding to the dominant NW-SE fjord direction (Rasmussen 1952, 1957, 1962).

The occurrence of considerable deposits of agglomerate in Suður- 
oy was observed earlier and mentioned briefly by Forchhammer (1924), Geikie (1880), Helland (1880), Bøggild (1922) and Walker and Davidson (1936), but none of these authors suggested a connection with fissure eruption.

\section{Suðuroy}

On the north-eastern side of Suđuroy the area within which the tuff-agglomerates occur measures about $10 \mathrm{~km}$ in length and about $2 \mathrm{~km}$ in breadth. Since the tuff-agglomerates pass below sea level towards the north and east these figures are minimum figures. The tuff-agglomerates can be seen at and close to the coast on the north side of Hvalbiarfjørður from the old landing place as far as the east side of Reyðibarmur, a distance of about 1,700 m, on the south side of Hvalbiarfjørður from Flekksá as far east as Myrkagjógv and from there towards the south into Lónin and Hvannhagi. In addition, they appear in watercourses and gullies on the north side of Trongisvágur from Myllá (Bláfossur) to the area west of Ranndalsá at Froðba.

At Reyðibarmur, which is a very prominent reddish coastal cliff about $550 \mathrm{~m}$ long on the north side of Hvalbiarfjørður, almost the whole of the coast section is formed by the loose eruptive products of the tuff-agglomerate zone.

Towards the west the cliff profile is limited by intrusive basalt, which occurs here on the shore. It forms an intrusive contact with the agglomerate in the coastal cliff and sends large apophyses up into it. In the agglomerate, which is usually brownish or greyish, bombs, lapilli and rock fragments can be seen. The exposure of tuff-agglomerate reaches here a height of about $30 \mathrm{~m}$.

At about the middle of the cliff section a basalt mass, which is about $70 \mathrm{~m}$ wide at the coast, intrudes the tuff-agglomerate zone up to a height of about $10 \mathrm{~m}$, where it branches out into long apophyses. East and west of this the tuff-agglomerates are red, frequently bright red. West of the intrusive basalt mass the tuffagglomerate zone reaches a height of about $50 \mathrm{~m}$; in the $10 \mathrm{~m}$ above it can be seen alternating with thin basalt flows belonging to the middle basalt series.

The eastern part of the cliff section in Reyðibarmur consists of a deposit of coarser and finer pyroclastic material with a grey to 
brownish colour. This is overlain by a thin red tuff bed and thereafter by the lavas of the middle basalt series; the upper boundary has a fairly regular course and dips north-east, cutting sea level at the waterfall east of Reyðibarmur.

From Reyðibarmur the tuff-agglomerate zone continues in towards the west, where it lies above the intrusive basalts that can be seen along the coast. However, there are only occasional exposures and the zone appears to disappear approximately above the old landing place.

At the watercourse west of Reyðibarmur the following profile was measured: $0-12 \mathrm{~m}$ intrusive basalt, $12 \mathrm{~m}-30 \mathrm{~m}$ scree and gravel, $30 \mathrm{~m}-70 \mathrm{~m}$ tuff-agglomerate, reddish (the uppermost approximately $10 \mathrm{~m}$ a transition zone showing interlayering with basalt), $70 \mathrm{~m}$ - lavas of the middle basalt series.

At the watercourse west of Hamranes the following profile was measured: 0 to about $35 \mathrm{~m}$ intrusive basalt, about $35 \mathrm{~m}-55 \mathrm{~m}$ tuff-agglomerate, $55 \mathrm{~m}$ - the lavas of the middle basalt series.

On the south side of Hvalbiarfjørður the tuff-agglomerates can be seen at Flekksá from about $100 \mathrm{~m}-140 \mathrm{~m}$ above sea level. They are underlain by intrusive basalts, from which apophyses go up into the tuff-agglomerate zone, which is in turn overlain by the middle basalt series.

Between Flekksá and Tjørnunes only scattered exposures of the tuff-agglomerate zone can be seen. Tjørnunes consists entirely of intrusive basalt; in towards the cliff at the back the basalt is covered by tuff-agglomerates. Tuff-agglomerates are also found both east and west of Tjørnunes, whereas they are not seen above sea level over a shorter distance - about $300 \mathrm{~m}$ - between Tjørnunes and Snæbjarnarhol. Here the whole cliff appears to consist of lava flows belonging to the middle basalt series. Farther east as far as Myrkagjógv and south as far as Lónin, the tuff-agglomerates near the coast are underlain by intrusive basalt. They are overlain by the middle basalt series.

In Akraskor, north of Lónin, the following profile occurs in the cliff just west of Hvannhólmur, from the base upwards: intrusive basalt with irregular columnar structure; tuff-agglomerate penetrated from below by intrusive basalt; intrusive basalt with regular vertical columns and then tuff-agglomerates once more. On the south side of Akraskor the tuff-agglomerates, which in towards 
the scree are bright red, are bounded to the north by a broad intrusive mass. The boundary between the tuff-agglomerate and the middle basalt series lies immediately to the south of the scree at a height of about $60 \mathrm{~m}$. Just as at Reyðibarmur a transition zone can be seen at Lónin with alternating basalt (middle basalt series) and tuff-agglomerates.

In Hvannhagi the tuff-agglomerates are exposed on the shore at Stapin and Ribbingamúli. The flat coastal area immediately west of Stapin consists entirely of agglomerate and slag for a distance of about $150 \mathrm{~m}$. The coastal cliff in the innermost part of the small bay west of Stapin is composed of the top flows of the lower basalt series; these show increasing mixing with loose eruptive products towards the tuff-agglomerates in the coastal area west of Stapin. This could also suggest that we are near an eruptive site.

Local occurrences of the boundary between the tuff-agglomerate zone and the middle basalt series can be seen along the whole of the mountainside from Todnes south and west into the hanging valley with the small lake and thereafter to the east as far as a few hundred metres east of Frostgjógv. There are also frequent exposures of the boundary between the east side of Dysjarnar and Ribbingamúli. At Todnes (in the cliff facing north) this boundary is situated $110 \mathrm{~m}$ above sea level, west of Stapin $125 \mathrm{~m}$, east of Gásagjógv $150 \mathrm{~m}$, some $200 \mathrm{~m}$ east of Frostgjógv $150 \mathrm{~m}$, on the east side of Dysjarnar (at spot height 110) $110 \mathrm{~m}$, in Myrkagjógv $90 \mathrm{~m}$ and in the easternmost part of Hvannhagi (approaching the coast towards Ribbingamúli) $85 \mathrm{~m}$ above sea level.

The boundary between tuff-agglomerate and underlying intrusive basalt can be seen in Myrkagjógv, where it is situated at a height of $70 \mathrm{~m}$ and in the easternmost stream in Hvannhagi, where it is situated at a height of $60 \mathrm{~m}$. The boundary can also be recognized in the easternmost part of Hvannhagi (approaching the coast towards Ribbingamúli). The thickness of the tuff-agglomerate zone itself is therefore $20 \mathrm{~m}$ in Myrkagjógv, $25 \mathrm{~m}$ in the easternmost stream in Hvannhagi, while approaching the coast towards Ribbingamúli it only reaches about $5 \mathrm{~m}$.

Approaching Ribbingamúli (fig. 20) the cliff face from the beach up to the middle basalt series consists mainly of intrusive basalt. Tuff-agglomerates can be seen in the cliff between the intrusive basalts and the middle basalt series but in general amount to only 


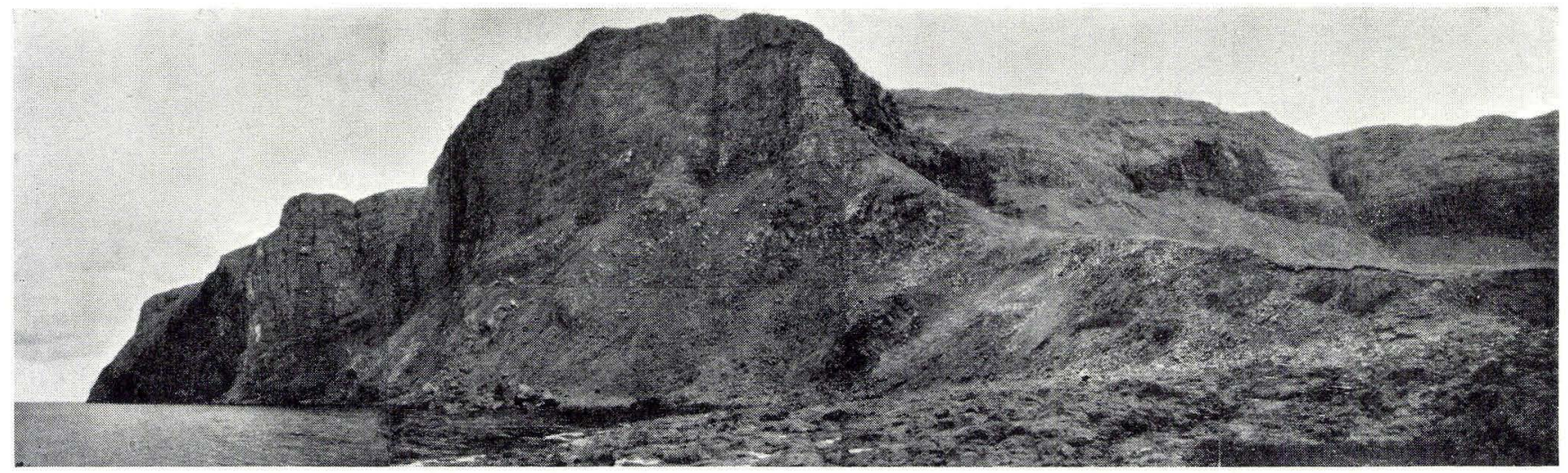

Fig. 20. Ribbingamúli and the south coast of Hvannhagi. In the foreground the lower basalt series is visible, and in the centre, intrusive basalt and tuff-agglomerate. At the top, the middle basalt series. 
a few metres. From time to time they occur as inclusions in the intrusive basalt. It is not uncommon to see more or less pronounced bedding in the tuff-agglomerates.

In the hanging valley in the north-western part of Hvannhagi, the boundary between the tuff-agglomerate zone and the middle basalt series is sinuous. East of Gásagjógv the tuff-agglomerates are interrupted by intrusive basalt, which goes right up to the middle basalt series. The boundary here is about $150 \mathrm{~m}$ above sea level. From here it rises regularly towards Grønagjógv; west of Gásagjógv it is $170 \mathrm{~m}$, on the east side of Grønagjógv $190 \mathrm{~m}$, but on the west side of Grønagjógv $170 \mathrm{~m}$ above sea level. This corresponds approximately to what is seen on the south side of the hanging valley, where the boundary about $200 \mathrm{~m}$ east of Frostgjógv is at a height of $150 \mathrm{~m}$, on the east side of Frostgjógv at $180 \mathrm{~m}$, but on the west side of Frostgjógv at a heigth of $165 \mathrm{~m}$. At the stream entering the lake on the north side the boundary between the tuff-agglomerate zone and the middle basalt series is $150 \mathrm{~m}$ above sea level. The tuff-agglomerate zone is transected here by a large intrusive basalt mass, which goes right up to the middle basalt series. At the stream entering the lake on the south side (watercourse from the gjógv) the lavas of the middle basalt series north of the gjógv can be seen as far down as $140 \mathrm{~m}$ (below this they are covered by vegetation); south of the gjógv the tuffagglomerates go up to $180 \mathrm{~m}$. They are underlain south of the gjógv by intrusive basalt. A wide dyke-like apophysis runs up through the whole of the gjógv.

Along the north side of Trongisvágur the tuff-agglomerate zone is exposed in streams and gullies between Myllá (Bláfossur) in the west and Húsagarðsá in the east. Its upper boundary is usually exposed and corresponds to the lower boundary of the middle basalt series. On the other hand, the lower boundary of the tuff-agglomerate zone is only shown approximately, since it is usually covered by vegetation. Occasionally, e.g. at the stream west of Tvørá, at Tippisá and at Sílá, agglomerates occur at a lower level than the boundary shown. These are considered to have slipped. At Myllá (Bláfossur) the tuff-agglomerate can be seen as far down as about $140 \mathrm{~m}$ above sea level, while the boundary between the tuff-agglomerate zone and the middle basalt series is at a height of $185 \mathrm{~m}$. At Svalbarðaá it was possible to measure three profiles through the tuff-agglomerate zone. In the middle profile 
the agglomerate can be followed from about $125 \mathrm{~m}$ to $160 \mathrm{~m}$ above sea level, but the profile is not exposed throughout its length. In the stream about $400 \mathrm{~m}$ west of Tvørá the upper boundary of the zone is situated at $195 \mathrm{~m}$; the agglomerates are exposed in places down to about $160 \mathrm{~m}$. In Tvørá tuff-agglomerates can be observed from about $155 \mathrm{~m}$ to $185 \mathrm{~m}$ above sea level. The material is coarser downwards and finer upwards, and a bedded arrangement of the components of the agglomerate can be seen. At the gjógv east of Tvфrá the agglomerate is exposed from about $160 \mathrm{~m}$ to $180 \mathrm{~m}$ above sea level. As at Tvørá the lower part is coarser and the upper part finer and better bedded. At Tippisá (Hválsgjógv) observations were made in places from about $170 \mathrm{~m}$ to $200 \mathrm{~m}$ above sea level. At Sílá observations were also made locally from about $140 \mathrm{~m}$ to about $170 \mathrm{~m}$ and at the watercourse west of Leirgjáarkneysi from about $160 \mathrm{~m}$ to $170 \mathrm{~m}$ above sea level. At Húsagarđsá tuff-agglomerate can be seen from about $145 \mathrm{~m}$ to $165 \mathrm{~m}$ above sea level on the eastern side of the watercourse. On the western side of the watercourse (about $25 \mathrm{~m}$ farther to the west) the upper boundary lies about $8 \mathrm{~m}$ higher.

\section{Tindhólmur and Vágar}

On the north-west side of Vágar the tuff-agglomerate zone can be observed in the coast section from the area west of the village of $\mathrm{B} \varnothing$ ur to the village of Gásadalur and northwards in gullies and watercourses from Gásadalur towards Barðiðð.

Between the small bay east of Hvalsker and the bay east of Akranes the tuff-agglomerate can be seen alternating with the lowest flows of the lower basalt series in the coast section. The agglomerate wedges out in the easternmost part of the bay east of Hvalsker and its place is taken eastwards by a tuff bed. Immediately east of Húnagjógv the thickness of the agglomerate is about $6 \mathrm{~m}$ and midway between Húnagjógv and Hvalsker about $3 \mathrm{~m}$. In the westernmost part of the small bay east of Akranes the tuffagglomerates and the flows of the middle basalt series are cut off by intrusive basalts from the west, the limit being a vertical line with an irregular course (fig. 44).

After this, agglomerates are not seen again until the vicinity of Akranesfossur, since Akranes and Akranessker consist entirely of intrusive basalt. In the cliff face below Akranesfossur (fig. 21), 


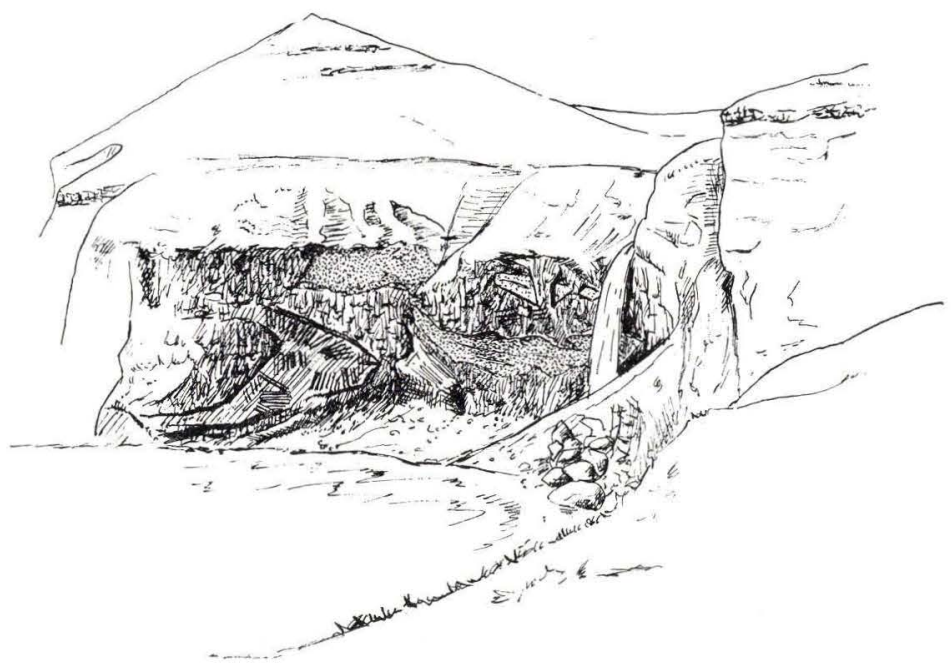

Fig. 21. Intrusive basalt with inclusions of tuff-agglomerate and clayey sediments at Akranesfossur.

which consists almost exclusively of intrusive basalt, there are large inclusions of agglomerate and clayey sediments belonging to the coal-bearing sequence. In addition, agglomerate can be seen in the stream at Akranesfossur from the edge of the scarp to $72 \mathrm{~m}$ above sea level, at one place alternating with basalt from the middle besalt series. In the large scree between Akranes and Gásadalur Bíggjaruro (fig. 22) - the whole of the area between the lower basalt series, which can be seen down towards the coast, and the middle basalt series, which is visible as a vertical cliff above the scree, consists of intrusive basalt and disrupted and broken-up inclusions of agglomerate and fragments of the coal-bearing sequence.

North of Gásadalur agglomerates were observed together with intrusive basalt above the coal-bearing beds in all open gullies and watercourses between Streymnes and Barðið. However, it is only locally that both the lower and upper boundaries are visible, e.g. in the watercourse north of Sæurðardrangur; the lower boundary here is at a height of $232 \mathrm{~m}$ and the upper boundary at a height of $258 \mathrm{~m}$. At Skrápsgilio the lower boundary lies at a height of about $245 \mathrm{~m}$ and the upper boundary at a height of about 270 m. Alternation between tuff-agglomerate and lavas of the middle basalt series can be seen locally, e.g. at Streymnes and at Sæurðar- 


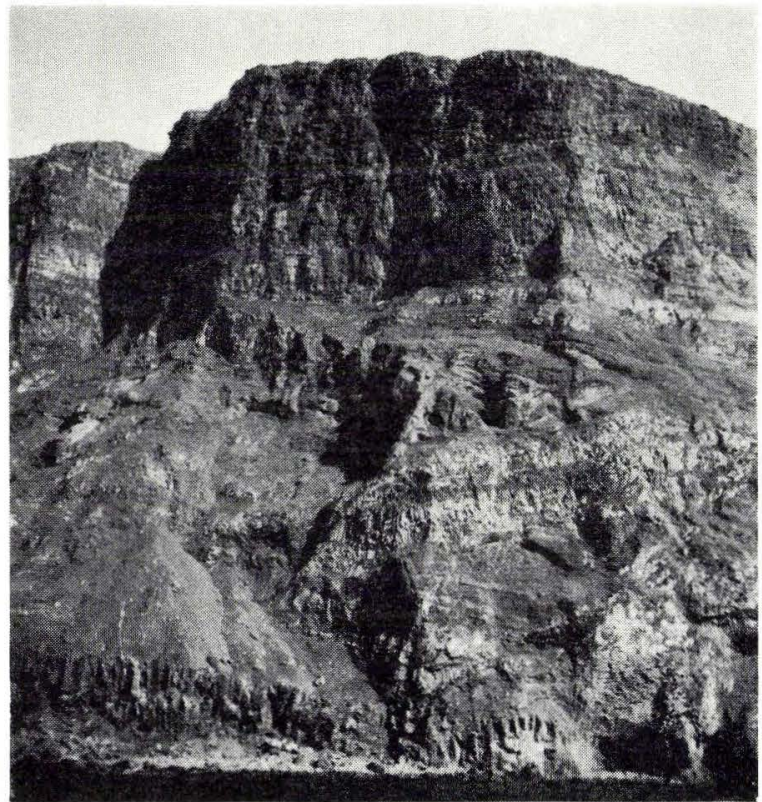

Fig. 22. Biggjarurð. The lower basalt series is visible at sea level, with intrusive basalt and tuff-agglomerate above it. At the top, the middle basalt series.

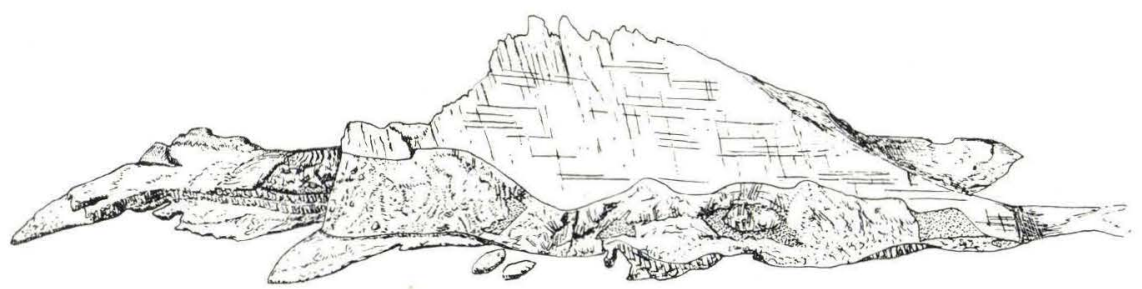

Fig. 23. South side of Tindholmur. On the coast towards the west there are flows of the lower basalt series, overlain by tuff-agglomerate and intrusive basalts. The uppermost lavas belong to the middle basalt series. 
drangur. This can also be seen at Víkar above the bay west of Víkar and at Reipsáfossur.

On Tindhólmur the tuff-agglomerate zone occurs in the vertical cliff face on the south side of the island between the lower basalt series along the coast and the middle basalt series higher up in the cliff. As at Bíggjaruro the agglomerates are broken up and included in intrusive basalt together with fragments of the coal-bearing sequence. At this locality the upper boundary of the tuffagglomerate zone is very sinuous (fig. 23). 


\section{The middle basalt series}

The lower boundary of the middle basalt series is, as mentioned, sometimes developed as a transition zone with alternation between tuff-agglomerate and thin basalt flows. This can be seen on both Suðuroy and Vágar and makes it likely that the lava production that led to the formation of the middle basalt series started already during the final stage of the explosive phase.

The middle basalt series forms the whole of the northern part of Suðuroy, most of Vágar, the northern part of Streymoy and the north-western part of Eysturoy. In the middle of Suðuroy (between Hvalba and Fámjin), on Tindhólmur and in the westernmost part of Vágar (west of Akranes-Víkar) it overlies the older rocks already described. In the southern part of Streymoy, on Esturoy and the other islands it is nearly always overlain by the upper basalt series.

After the initial explosive phase the volcanism was continuous, with very little explosive character; the lava flows were poured out one above the other without any major pauses between. The flow thickness is much less in the middle basalt series than in the other two series and the middle basalt series also differs structurally and morphologically from the other two series. The typical landscape developed is thus different from the pronounced "stepped" landscape of the other two series; it is soft and convex (fig. 24), and the development of the landscape is probably attributable to the great susceptibility to weathering high up, which is particularly characteristic of the middle basalt series, and subsequent transport of the weathered material to lower-lying areas. The individual lava flows are usually thin, from a fraction of a metre to 1-2 $\mathrm{m}$; they often form smaller sequences up to about $20 \mathrm{~m}$ or somewhat more, e.g. the B-horizon flows (see p. 15). It is often difficult to decide whether one is dealing with a complete lava flow or merely a part of a flow - a flow unit -, e.g. smaller, successive escapes of lava from a partly consolidated lava flow (fig. 25, 26). In the upper part of the middle basalt series the flow thickness increases some- 


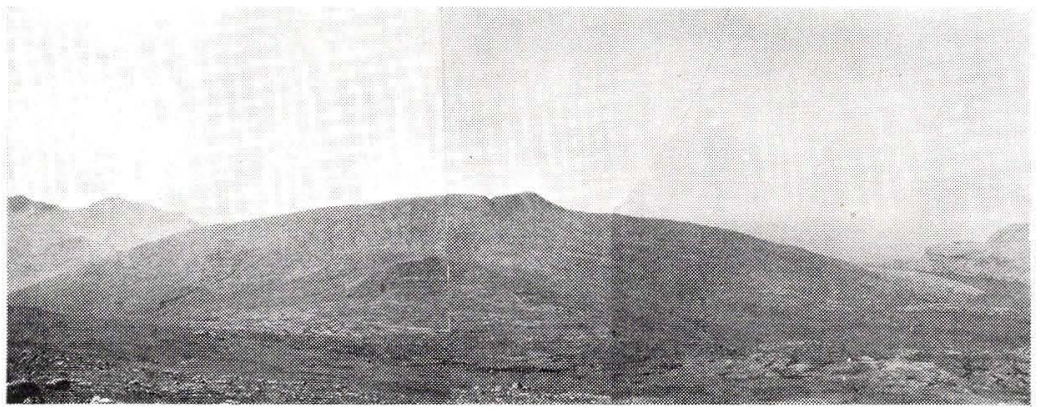

Fig. 24. Typical landscape form of the middle basalt series (Tungufelli, Vágar).

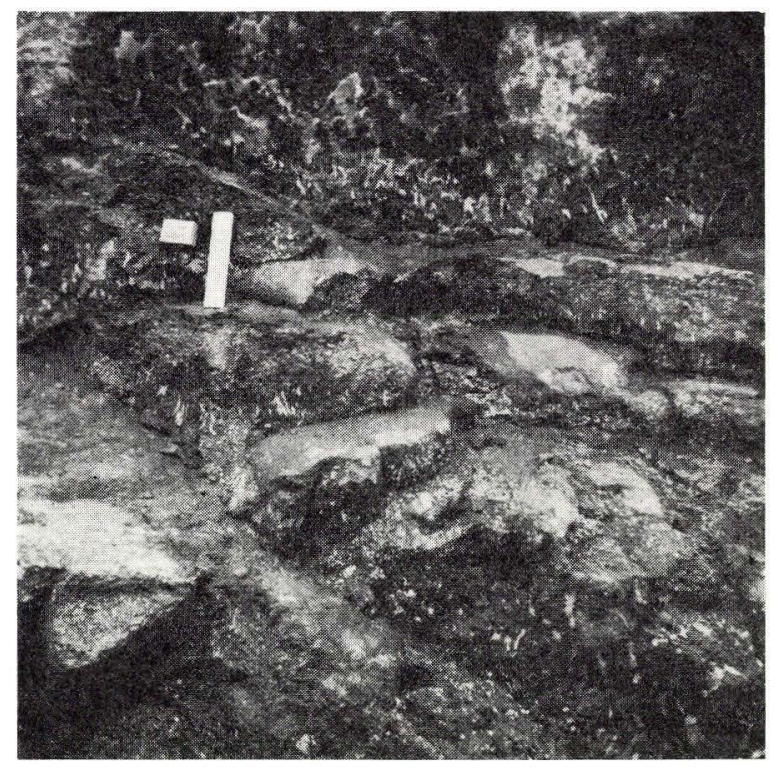

Fig. 25. Flow units in the middle basalt series.

what and can exceptionally be up to $10 \mathrm{~m}$. The individual lava flows show at the base a zone with more or less vertical pipes; above this is a more compact middle zone, and at the top a highly vesicular zone, where gases have been liberated as a result of the reduced pressure in the lava at the surface. The pipes and vesicles are filled with secondary minerals such as zeolites, opal, quartz and calcite. Ropy lava surfaces can be seen everywhere 


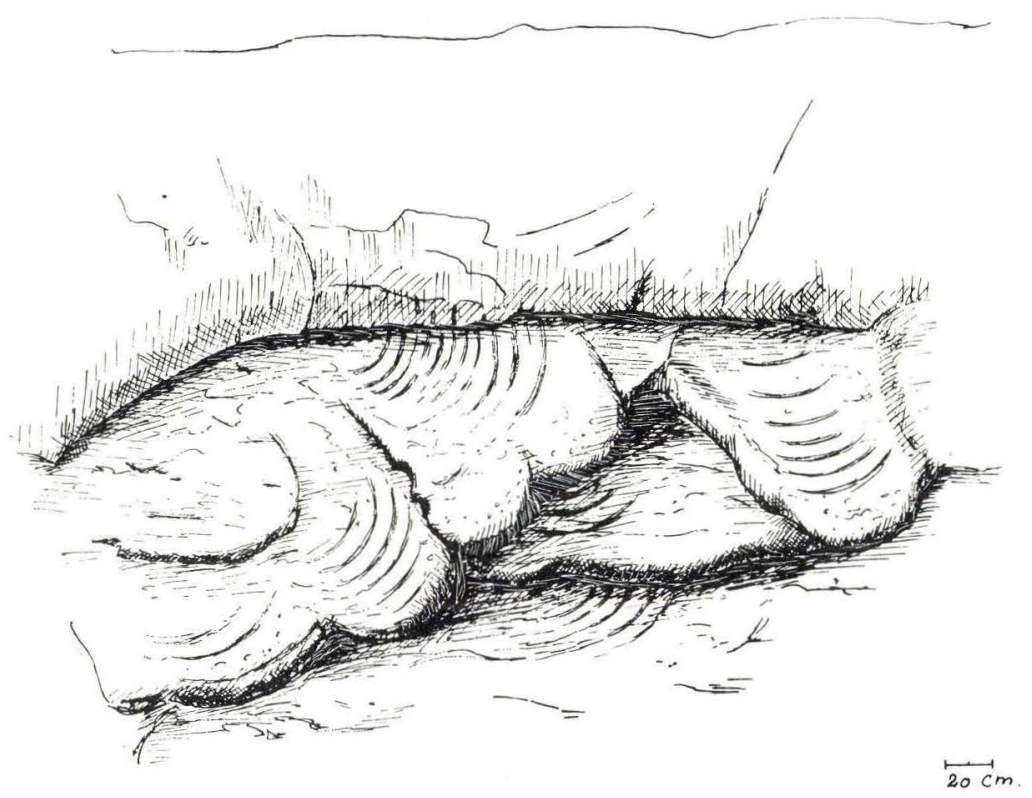

Fig. 26. Flow units in the middle basalt series (lava tongues).

(fig. 27), and casts of such surfaces often occur on the lower surfaces of the lava flows. Flow structures, flow lines and drawnout vesicles are generally prominent in these lava flows; sometimes they are so prominent that they have actually given rise to a lamellar jointing in the rock.

The elongated intrusive bodies with circular or oval cross section, which must be considered to be filled-up lava tunnels, can often be seen in both the middle and upper basalt series. One of these phenomena near the beach just west of the village of Rituvík was already described by Forchhammer in his diary from 1821. It has an elliptical cross section: major axis $3.25 \mathrm{~m}$ and minor axis $1 \mathrm{~m}$. Its exposed length is about $18 \mathrm{~m}$, after which it disappears in considerably thinner form under a moraine. Contact effects can be seen over the whole surface and apophyses go into the country rock. A similar phenomenon can be seen on the north-west point of Sandoy. Inland its breadth is $10.5 \mathrm{~m}$; it is broader farther out; it is visible in cross section above sea level in the small island (Trøllhøvdi) north of Sandoy. Other examples can be mentioned from the coast between Velbastaður and Kirkjubøur and at Bláfossur on the south side of Kollafjørður. Lava tunnels of similar 


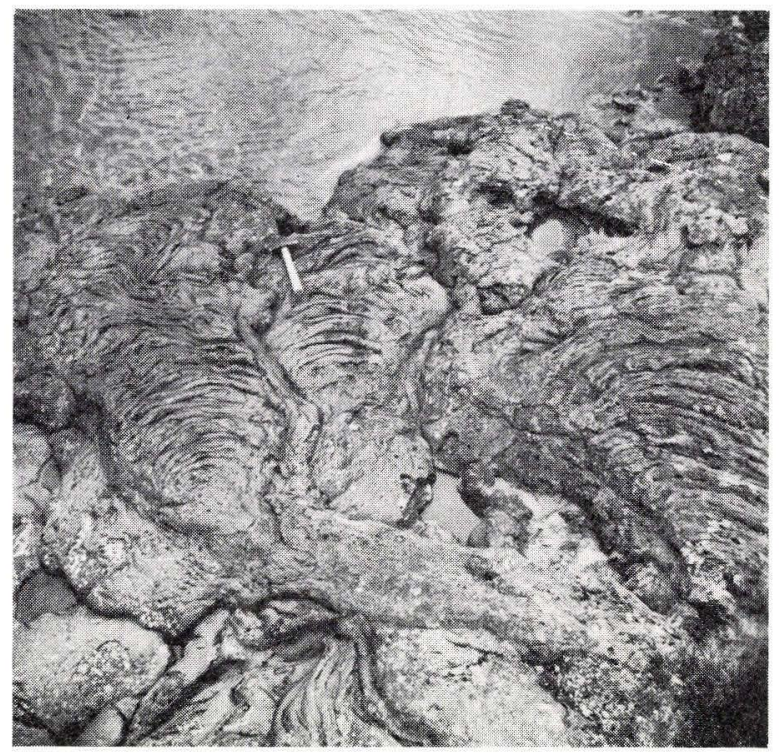

Fig. 27. Ropy lava in the middle basalt series.

dimensions, which have not been filled up, are also frequently seen; for example, they can often be observed on the northern islands.

Tuff occurs very rarely in the lower part of the middle basalt series and always only as very thin beds. Farther up in the series tuff beds become commoner; for example, tuff is quite widespread just under the flows of the B-horizon. At Argisfossar in central Streymoy there is a tuff bed of 1-3 $\mathrm{m}$ with green and red colour; it has been worked earlier, and at the village of Eiði on Eysturoy there is a tuff bed of $1-1.5 \mathrm{~m}$, which is also green and reddish brown in colour.

A purely local interbasaltic formation containing basaltic glass occurs on the south-west side of Grímsfjall and can be mentioned here. At about $95 \mathrm{~m}$ above sea level in the mountain wall, a basalt flow can be seen which wedges out towards the north. On the west side its horizontal extent is estimated to be about $50 \mathrm{~m}$; on the south side it is about $15-20 \mathrm{~m}$, after which it disappears under the turf. Its maximum thickness is about $6 \mathrm{~m}$. The flow is underlain by clayey sediments $10-15 \mathrm{~cm}$ thick, and overlain by clayey sediments $15-35 \mathrm{~cm}$ thick. It shows a faint pillow structure, particularly at the base; its upper part is more vesicular, is full of zeolites and has less glass. 
Here and there in both the middle and upper basalt series sideromelane tuff occurs (Noe-Nygaard 1939), which is a formation that indicates very rapid and effective cooling of the glass particles in the tuff. Sideromelane is common in the Quaternary volcanic formations in Iceland, where these have been formed under subglacial conditions; but sideromelane can also be formed under water.

During mapping work we observed some sideromelane tuff in the middle basalt series at Vestmanna and Eiði and in the road tunnel between Árnafjørour and Depil, and in the upper basalt series on Nólsoy and Fugloy. The Faeroese occurences of sideromelane probably indicate that the vents for these tuff beds lay below water at the time the ash was formed; but we cannot determine whether the eruptions took place in lakes on land or in a shallow-water marine area.

The flows in the middle basalt series are usually separated by vesicular and welded scoriaceous horizons; the series, in particular its lower part, gives a much greater impression of being a welded unit than the other two series. This impression of unity is created particularly clearly in the vertical headlands facing the sea, where a characteristic striping due to flow structure and erosion (wind erosion) of the less resistant vesicular zones can often be observed (fig. 28).

Just as there can hardly be any doubt that the eruptive activity during the formation of the lower basalt series was related to very large elongated fissures, there are very good grounds for believing that the volcanic activity that was responsible for the formation of the lavas of the middle basalt series was localized to eruptive sources of considerably smaller size. The remains of some of these feeders can be seen in the middle basalt series in natural sections through the volcanic vents occurring along sounds and fjords. They are visible in coast section varying from less than $50 \mathrm{~m}$ to about $1.5 \mathrm{~km}$, where observations seem to show that they must have had an elongated or elliptical form.

During the field work 10 vents of this type were observed in the coast section; 1 on Vágar, 2 on Koltur, 1 on Streymoy. 1 on Kallsoy, 1 on Borðoy, 3 on Viðoy and 1 on Fugloy. The vents at all these localities are clearly delimited; more randomly occurring agglomerate masses have not been included (Rasmussen 1962).

South of Marragjógv on Vágar there is a vent on the coast facing Vestmannasund. Along the shore it measures about $50 \mathrm{~m}$; 


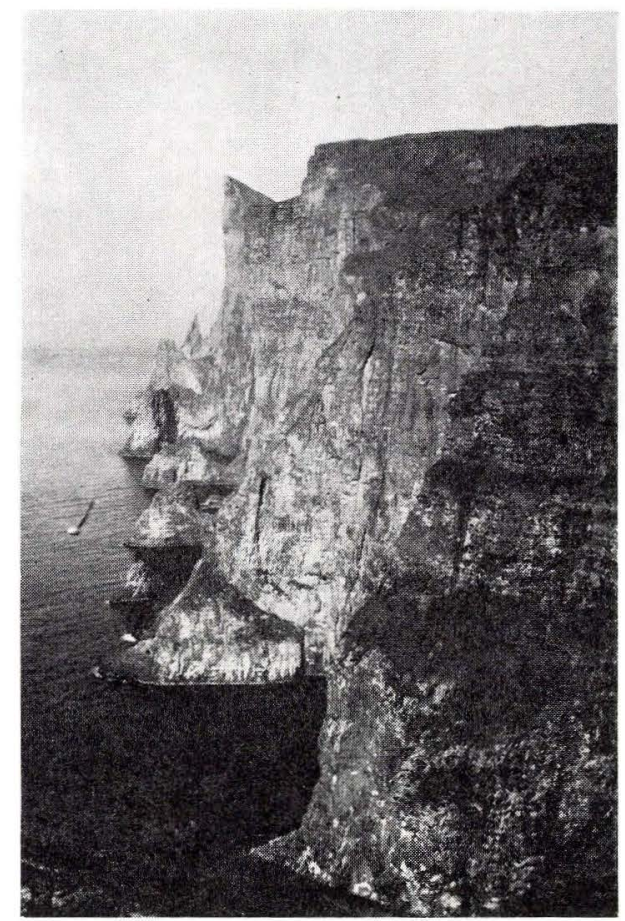

Fig. 28. The middle basalt series. North-west coast of Streymoy.

here it transects the regular basalt flows, becomes narrower upwards and is overlain at a height of about $20 \mathrm{~m}$ by a tuff bed and by lava flows (plagioclase-porphyritic basalt). Between the country rock and the pyroclastic material filling the vent there is intrusive basalt (also plagioclase-porphyritic), which apparently has formed a mantle about $1.5 \mathrm{~m}$ thick round the agglomerate, with clear thermal contact against both the country rock and the agglomerate inside. Ashy material seems to be predominant at the sides and towards the top, while porous lava is predominant in the middle and downwards. The colour of the ash varies from grey to reddish, the ash being grey in the middle and reddish at the sides and towards the top. The coarser material varies in size from pea size to about $1 \mathrm{~m} ; 15-20 \mathrm{~cm}$ is however the commonest. The blocky material consists predominantly of plagioclase-porphyritic basalt and very porous basalt. Apophyses extend from the intrusive mantle into both the agglomerate and the tuff bed above.

Just north of the village of Koltur, north of Gróthústangi, there 


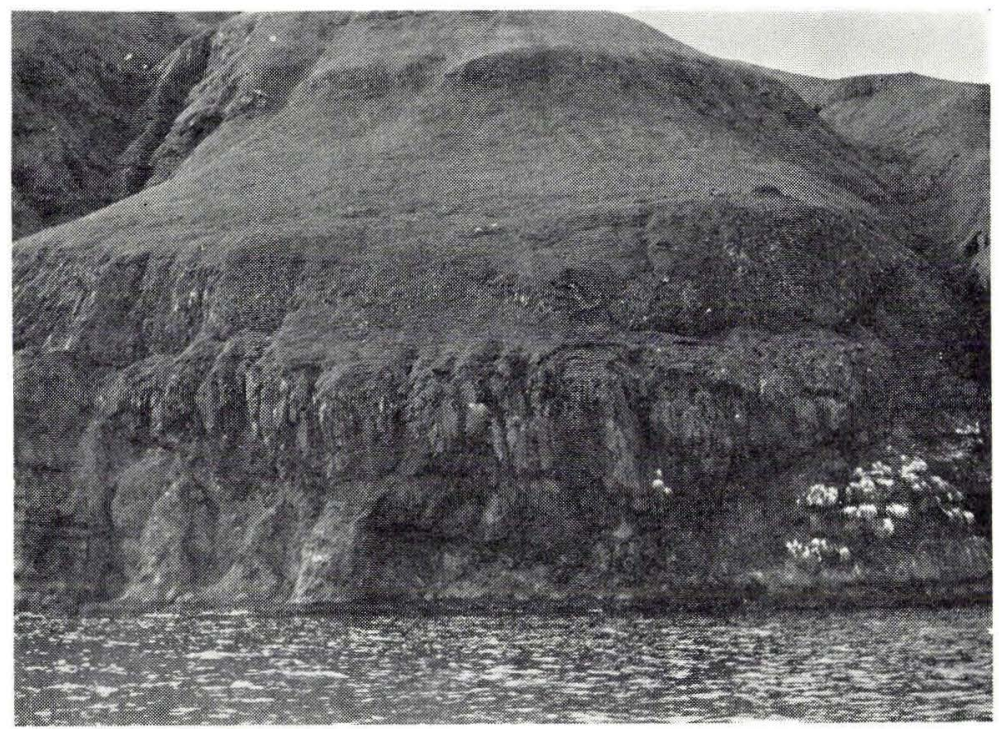

Fig. 29. Vent. North-east side of Koltursnakkur, Koltur.

is an exposure of agglomerate, which indicates the presence of a small vent. In addition, agglomerate occurs locally in the mountain wall farther north and also on the west side of the island.

North-east side of Koltursnakkur. Between the northernmost two gullies on the north-east side of Koltursnakkur the basalt flows are transected by an agglomerate mass, the boundary being approximately vertical. The surface of the agglomerate has been eroded in the middle and the depression later filled by basalt (fig. 29).

Dalsnipa, Streymoy. Geikie (1896) describes an agglomerate area lying north of Dalsnípa as being a cross section through five small vents. In our opinion (Rasmussen 1962) this represents various sections through a narrow, elongated eruptive channel with NNW-SSE trend. In the stretch from Seyðaskor in the north to Dalsnípa in the south an agglomerate mass can be seen in the lower part of the cliff section. The agglomerate is limited towards the west by the dyke Str. 226, 227, 228 and 229, and towards the east by the steep cliff with thin regular basalt flows situated behind the agglomerate mass. It is therefore likely that this represents a vertical section through an eruptive channel with a length of about $1,500 \mathrm{~m}$ and a breadth estimated to be $10-50 \mathrm{~m}$.

North of Lambagiógv on the south-west side of Kallsoy a small 
vent can be seen in the coast section. Towards the north it is limited by a thin dyke. The boundary against the basaltic country rock dips slightly inwards.

A vent is situated on the north-west side of Borðoy at Svartiklett$u r^{*}$. The distance between the northern and southern boundaries of the agglomerate is about $50 \mathrm{~m}$, and both the northern and southern boundaries between the agglomerate and the basalt country rock dip outwards. The central area is strongly eroded and the depression filled with basalt, which is dark at the base and lighter above with columns arranged in a fan and pointing towards the agglomerate surface. In the coast profile it is overlain by two more basalt flows.

A vent occurs on the north-west side of Viðoy, south of the village of Viðareiði. It stands out in the vertical coast section with vertical boundaries between the agglomerate and the basalt flows on each side.

On the south-west side of Viðoy, Walker and Davidson (1936) mention a vent that is believed to feed an overlying lava flow. As at Svartiklettur there is here a depression in the agglomerate, which is filled with basalt with columns oriented at right angles to the surface of the agglomerate. There is a clear connection between the basalt in the depression and an overlying basalt flow, but no attempt will be made here to decide whether it has been a feeder for the basalt flow or whether this represents a lava flow that has filled the depression; the latter interpretation seems the most probable.

On the south-east side of Viðoy a vent occurs on the west side of Viðvík between the two gullies Gjógvin Stóra and Gjógvin Lítla. It can be seen for a distance of about $145 \mathrm{~m}$ along the coast and up to a height of about $20 \mathrm{~m}$ above sea level. It transects the regular basalt flows and its boundaries are approximately vertical on both the south and north sides. The agglomerates extend about $75 \mathrm{~m}$ northwards from the southern boundary and about $40 \mathrm{~m}$ southwards from the northern boundary. The two agglomerate areas are interrupted for a distance of about $30 \mathrm{~m}$ by a depression in the surface, which is filled with basalt. In the lowest part of the depression there is a smooth transition between agglomerate and basalt, while higher up there is a clear thermal boundary between

* This may be the same vent that Walker and Davidson (1936) describe as a vent from the north-west side of Kunoy, where we have been unable to observe any; if this is so it is placed incorrectly on their map. 


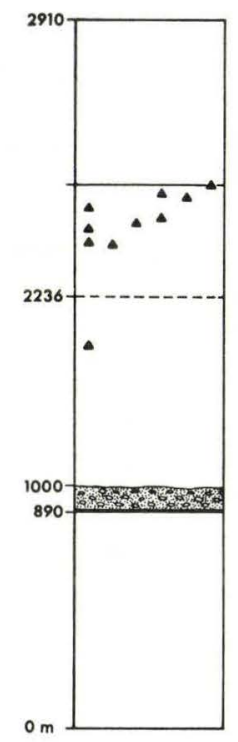

Fig. 30. Simplified section of the Faeroese sequence showing the stratigraphic positions of known vents.

them. Basalt aphophyses with flow structure can be seen in the agglomerate, especially towards the sides, and these sometimes extend right up to the overlying basalt flows. The blocks in the agglomerate are predominantly compact, blue basalt, with subordinate feldspar basalt.

Just east of the village of Kirkja on Fugloy, west of Nevið Óða, there is a small vent, which can be seen in vertical coast section. It is dome-shaped; its height and width are about $10-15 \mathrm{~m}$. The agglomerate has a thin mantle of intrusive basalt.

Fig. 30 shows a simplified section of the Faeroese sequence. The vents referred to, which comprise all the vents observed by us, are shown on the section. It can be seen that all these vents are situated in the middle basalt series in a zone from about the middle of the series up to the boundary area between the middle basalt series and the upper basalt series (C-horizon). These vents are found at the following localitites, the figure in brackets being the distance below the C-horizon: south of Marragjógv on Vágar (c $550 \mathrm{~m}$ ), north of Lambagjógv on Kallsoy (c $260 \mathrm{~m}$ ), at Dalsnípa on Streymoy (c $250 \mathrm{~m}$ ), on the north-east side of Koltursnakkur on Koltur (c $190 \mathrm{~m}$ ), at Svartiklettur on the north-west side of Borðoy (c 
$170 \mathrm{~m}$ ), south of the village of Viðareiði on Viðoy (c $150 \mathrm{~m}$ ), north of Koltursbygd on Koltur $c 95 \mathrm{~m}$, on the south-east side of Viðoy $(c 60 \mathrm{~m})$ and on the south-west side of Viðoy $(c 20 \mathrm{~m})$. The small vent that was described east of the village of Kirkja on Fugloy lies in fact above the mapped boundary middle basalt series - upper basalt series (C-horizon), but presumably in the boundary area itself however, since it is limited on each side by lava flows with characteristics typical of the middle series, while it is overlain by flows with characteristics typical of the upper series.

During the mapping work no vents were observed in the upper basalt series or the lower basalt series. The vent described at Froðba by Walker and Davidson (1936) is probably connected with the NW-SE trending eruptive fissure on Suðuroy (Rasmussen 1952), which was described in the section on the lower basalt series.

It can therefore be regarded as proved that the vents described were feeder channels for the lavas of the middle basalt series.

The map, fig. 31, shows that the tuff-agglomerate areas and thus the eruptive channels, which are presumed to have fed the lower basalt series, and whose origin and direction were determined by a pre-existing tectonic fracture system, have a NW-SE trend like the fjords. The map also shows that all the vents observed lie along the same NW-SE trending fjords; vents have never been seen inland, despite good possibilities for observation. It must therefore be assumed that eruptive activity during the whole of the volcanism was localized to these zones, and that the fjord formation since then has been determined by the same system of fractures (Rasmussen 1962).

The lavas of the lowermost about $200 \mathrm{~m}$ of the middle series vary very much in rock type. One type of lava is aphyric and resembles the lavas in the lower series, another type is porphyritic; this type increases in amount upwards, and a third type consists of olivine-rich lavas, which belong to a type which first becomes dominant in the upper basalt series. The main sequence of the middle series, however, consists predominantly of plagioclase-porphyritic basalts.

The porphyritic basalts of the middle series generally have a light-grey colour and a rough surface. There is only a slight colour difference between fresh and weathered surfaces. The porphyritic 


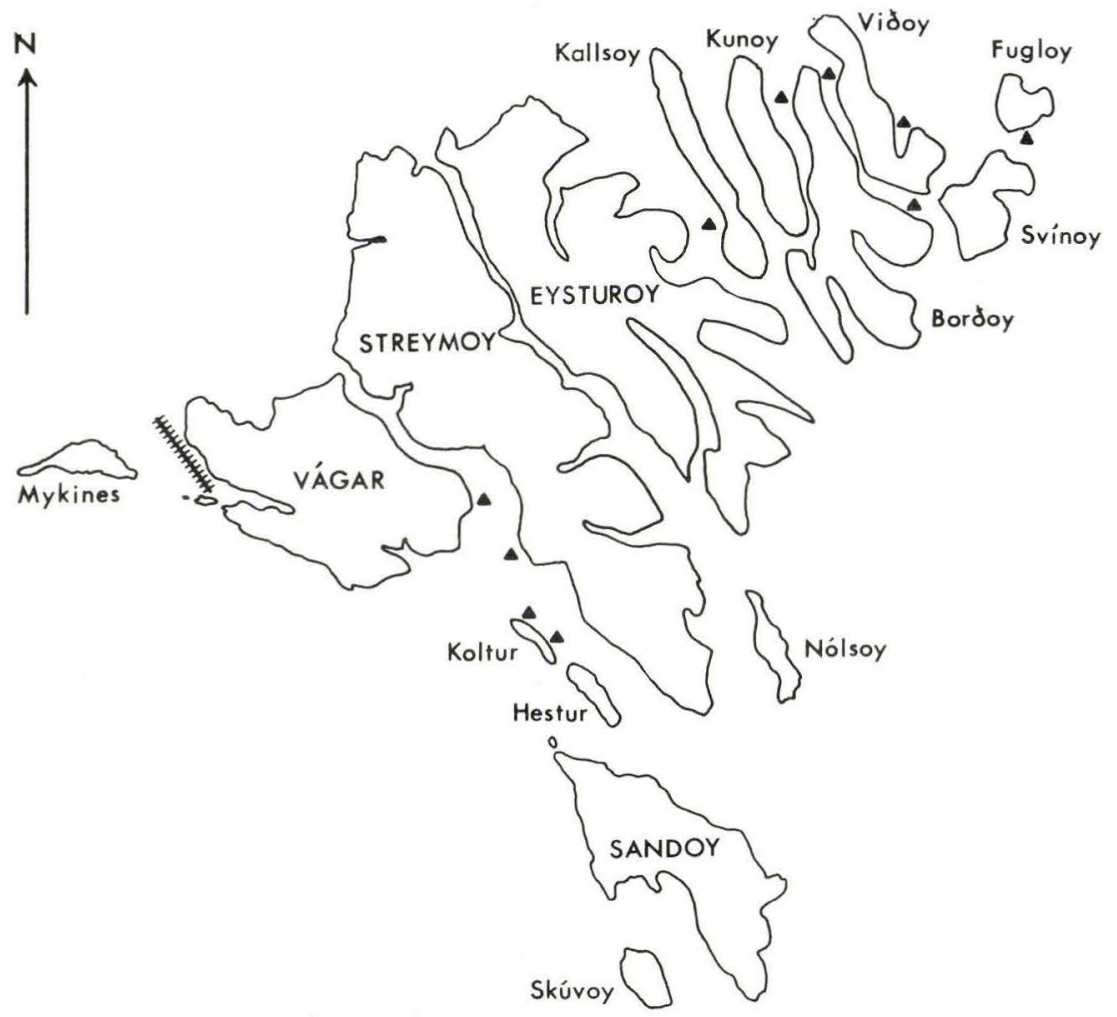

Sstóra Dímun

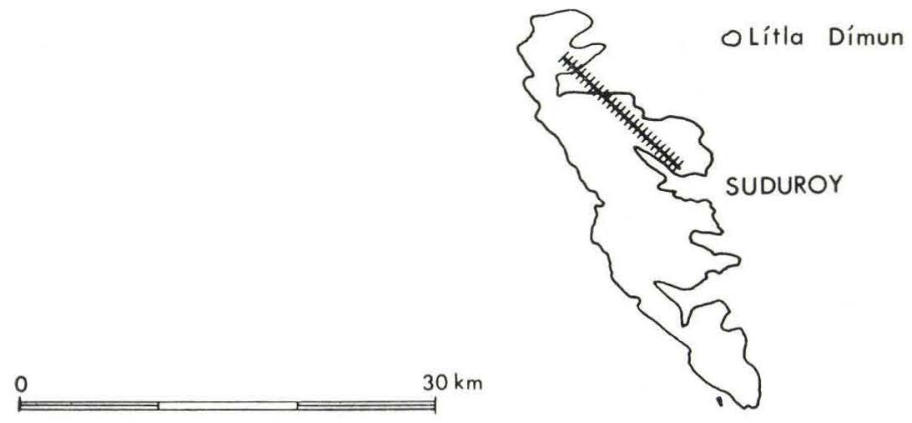

Fig. 31. Tuff-agglomerate zones and vents. 
lavas often crumble on weathering to give rounded surface forms and "sandy" screes. A few porphyritic flows are almost black; these have a smooth surface and weather to a sharp-edged gravel. The texture of the groundmass is nearly always intergranular.

Phenocrysts of olivine are only sparingly present and are always subordinate in number to clinopyroxene. Clinopyroxene occurs as phenocrysts, rarely more than 1-2 mm across; they have the same composition as those found in the aphyric lavas. The groundmass contains augite as well as pigeonite.

Plagioclase is the dominant phenocryst mineral, and constitutes from 10 to $30 \%$ of the rock. Individual plagioclase phenocrysts may reach a length of about $1 \mathrm{~cm}$ (in big-feldspar basalts several centimetres). Composite phenocrysts are common. In some flows a stellar grouping of the plagioclase laths is characteristic, and there are often one or two smaller phenocrysts of augite near the centre of the accretion. Many large plagioclase phenocrysts are fractured and show signs of incipient alteration. The anorthite content of the phenocrysts is about $66 \%$ in the cores and about $60 \%$ in the outer zones and in the groundmass. In very large phenocrysts the cores are generally bytownitic.

The average mineral composition of ten typical, porphyritic basalt flows from the middle series is:

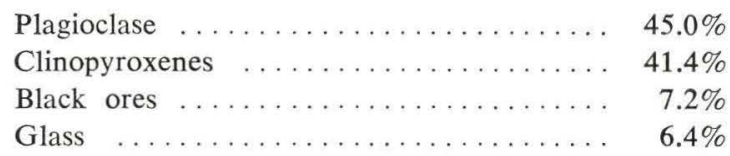

(Chemical analyses - atypical, however, with respect to the bulk composition - are given on p. 209 in the Memoir). 


\section{The upper basalt series}

After a further period of quiescence of unknown duration the third and last period of eruption, which led to the formation of the upper basalt series, commenced. The volcanism, which during the building-up of the whole of the middle basalt series gives an impression of having been continuous, had once again a rhythmic character, as during the formation of the lower basalt series.

The upper basalt series does not occur on Suðuroy, Mykines, Gáshólmur, Tindhólmur or Vágar. It does not occur either in the northern part of Streymoy or the north-western part of Eysturoy. Elsewhere in the islands it overlies everywhere the middle basalt series, except in eroded valley and fjord areas. Along the east side of the islands from Sandoy to Fugloy the upper basalt series is virtually the only part of the sequence present.

Since the upper basalt series, like the lower basalt series, is built up of regularly alternating basalts and tuffs, we find once more the stepped landscape with bare ledges and vegetation-covered slopes, but as neither the basalt flows nor the tuff beds in between generally reach the thickness that is common in the lower basalt series, the landscape is generally made up of smaller steps (fig. 32).

As mentioned in the outline of the stratigraphy, the boundary middle basalt series - upper basalt series (C-horizon) corresponds to the lower surface of a series of two to three or even more flows (exceptionally only one flow) of compact, blue basalt, which are separated by zeolite-filled vesicular zones, or more rarely thin tuff beds. They often show pronounced flow structure with flow lines and drawn-out vesicles. The top of the horizon basalts is almost everywhere developed more or less as an agglutinate, i.e. the surface, and occasionally also the underlying surface, is covered by a bluish-violet crust of loose eruptive products, especially lava splinters welded together by lava.

Where the succession around the C-horizon is most typical, the horizon basalt flows rest on a red tuff bed, which is underlain by a large-grained felspar basalt, often reddish-coloured at the surface, 


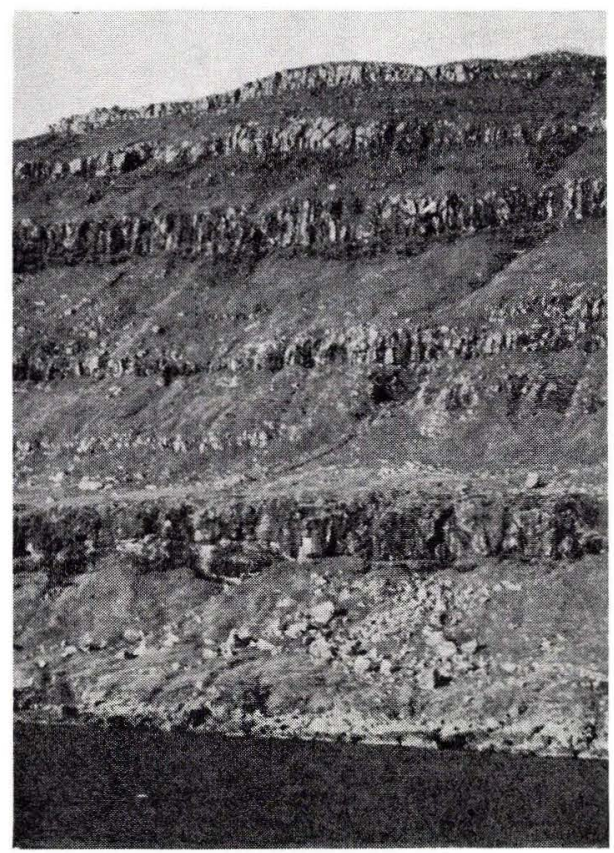

Fig. 32. Lava flows in the upper basalt series between Kaldbak and Kollafjørður.

with phenocrysts, frequently large plagioclase laths. In the tuff bed there are often yellowish-coloured, indeterminable impressions of plant fragments. The horizon basalt flows are overlain by finely speckled felspar basalt. It is, of course, not unusual to find departures from this sequence.

The boundary is shown with a black line on the map, but at certain localities where observation was particularly difficult or impossible it is shown with a broken line. In places where the conditions for observation were good and the horizon basalt was seen to be absent, or where its presence is at any rate very uncertain, the boundary level is shown with a dotted line.

The C-horizon flows did not flow out over an even land surface everywhere; locally the erosion left uneven hard masses round which the C-horizon lavas flowed; these masses have therefore for some time stood up as islands through these lavas.

The reason that we decided to ignore these local deviations when drawing the boundary surface between the middle and upper basalt series on the map, e.g. on the west side of Koltur and Hestur, on 


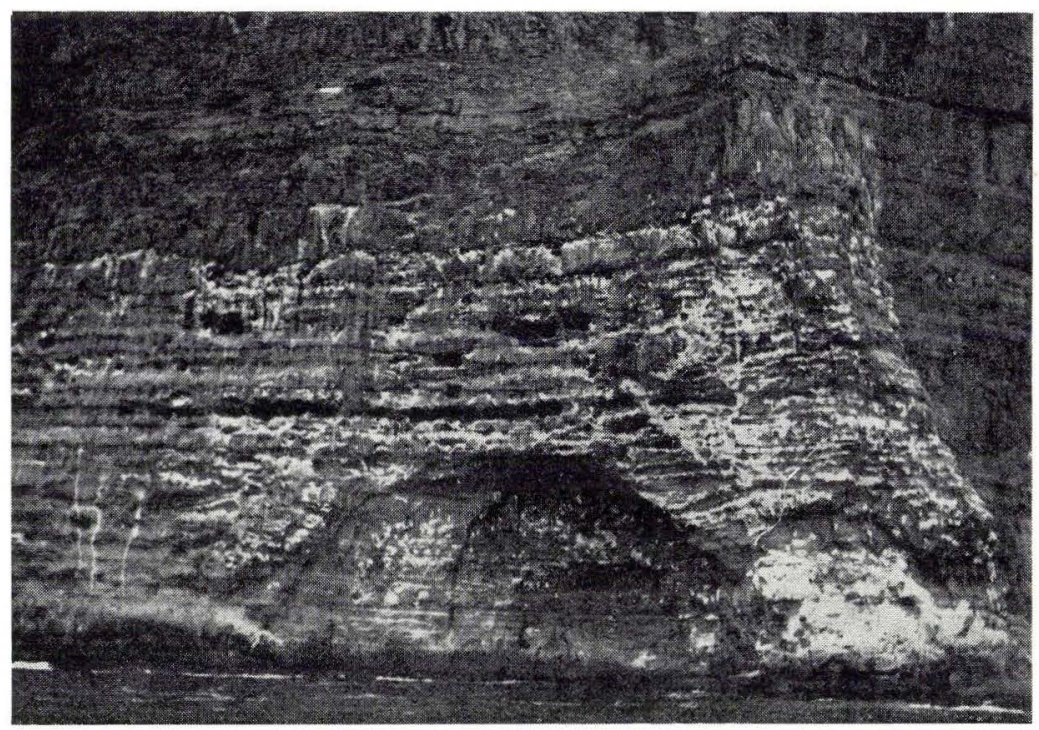

Fig. 33. The position of the C-horizon on the north-west side of Sandoy is clearly marked by the distribution of bird dung. The birds nest almost exclusively in the middle basalt series.

the south-west side of Sandoy and on the south side of Viðoy, are that we wanted to retain the general boundary level over the whole area in order to be able to base our measurements on it and that deviations are in general of minor importance.

The volcanic activity in the upper basalt series must have moved from east to west since the initial explosiveness can be traced at a lower level in the sequence in the eastern area than in the western. On the northern islands, around Klakksvík, we thus find explosive material below the C-horizon, while towards the west - in the area west of Árnadalstindur - we find explosive material from the C-horizon upwards. In other words, if mapping of the C-horizon had been undertaken from east to west instead of from west to east it would have had a somewhat lower position.

The underlying surface that the first lavas flowed out on to was probably an uneven, gently sloping surface, since at a few localities, e.g. at the north end of Hestur and in the mountain wall between Kaldbaksfjørður and Kollafjørður, it is possible to see an unconformity at the base of the lavas of the upper series. Whether this is due to the fact that an originally uneven, sloping or eroded land 
surface was covered by new lava, or whether there were weak tectonic movements in the preceding period cannot be determined with certainty at the present time.

Along the east side of Streymoy, from Sneis and Bollin in the north to Dyllan and Árnadalstindur in the south and in the area between Kaldbaksfjørður and Kollafjørður the C-horizon stands out in the landscape as a prominent, well defined line, which separates the soft, convex landscape characteristic of the middle basalt series as typically developed on Vágar and northern Streymoy from the typical benched or stepped landscape typical of the upper basalt series. In the mountain wall between Kollafjørður and Kaldbaksfjørður the unconformity referred to can be seen particularly clearly. Along the west side of Streymoy the conditions are somewhat less clear because the large Streymoy sill transects the horizon flows here. These flows are distinct on Sátan and TranturSkælingur, where they can be followed southwards to the north side of Gjáarbotnur. On the other hand, they cannot be found at all in the area between Gjáarbotnur and Norðradalur, where they may have thinned out or may merely have been displaced by the sill. South of Nororadalur the possibilities for observation were in general very poor and the level was mapped from a boat.

While there were no particular problems involved in tracing the C-horizon farther towards the east with reasonable certainty, it was much more difficult to trace it towards the west and south since the distance between the islands in these directions is greater and the boundary is not nearly so characteristically developed as in the northern islands. The boundary is therefore somewhat uncertain in these islands.

On Koltur three spot heights were measured on the presumed horizon, which moreover was mainly mapped from a boat. On the north side of Hestur there is as mentioned earlier an unconformity, since the flows between Ormur and Hestboði dip approximately SW, while the southern part of the island has ESE dip. The horizon flow, which meets the sea north of the landing place at the village of Hestsbygd, can be followed westwards to north of Byrgisstakkur, where it thins out. The C-horizon level can be followed thereafter in the cliff until it reaches sea level north of Loftið. The boundary between the two series on Koltur and Hestur is very uneven and locally unrecognizable, but the C-horizon level has been retained on the map here as at other places where there are local variation. In 


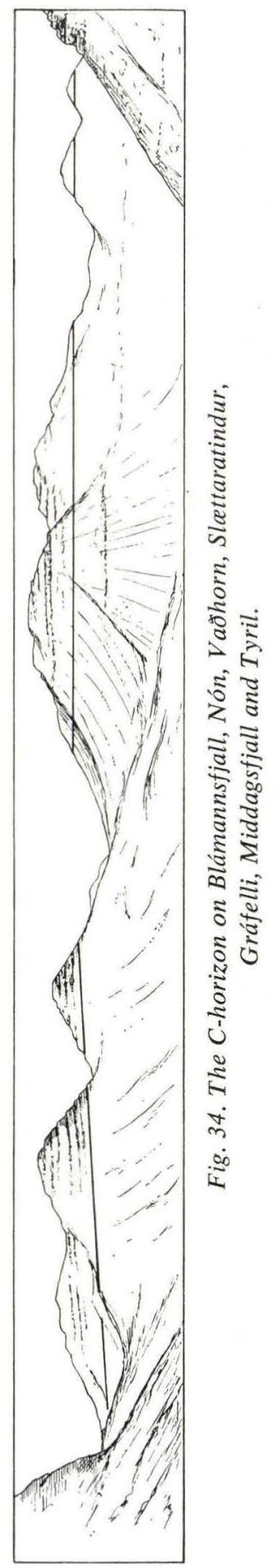




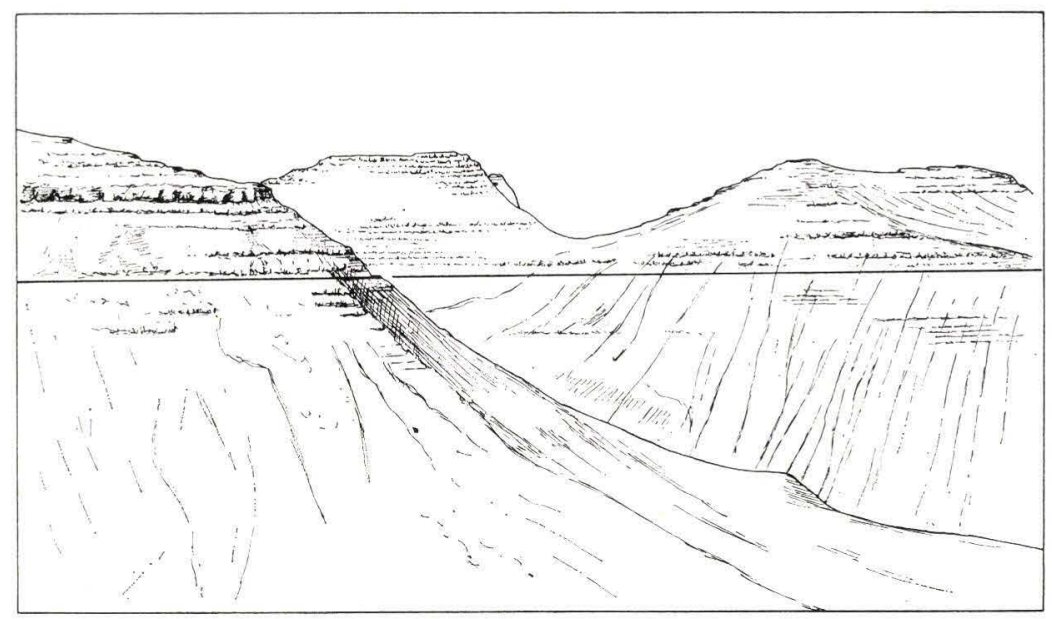

Fig. 35. The C-horizon on Middagsfjall, Gráfelli and Sandfelli.

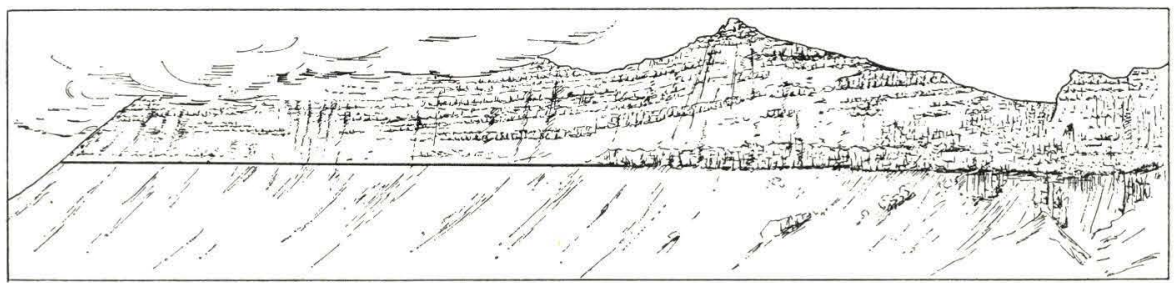

Fig. 36. The C-horizon on Mannssetur-Gráfelli.

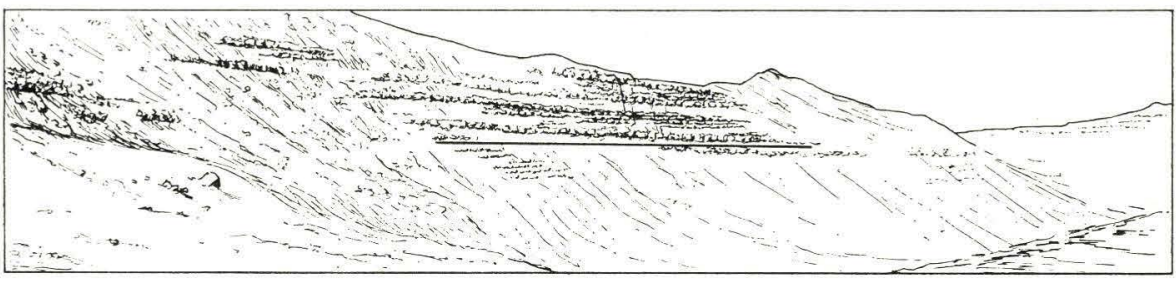

Fig. 37. The C-horizon on the north of Jøkladalur. 
the northern part of Sandoy the boundary middle basalt series upper basalt series is distinct (fig. 33), but the horizon basalt in this area is a large-grained feldspar basalt. Towards the south, on the other hand, the boundary becomes less typical; south of Søltuvík the entire mountain wall consists of basalts of the type found in the middle series, with the exception of a few single flows. On Skúvoy the presumed horizon flows, which also consist of large-grained feldspar basalt, are underlain by a red tuff bed about $1 \mathrm{~m}$ thick. On Stóra Dímun and Lítla Dímun the position of the C-horizon level could only be calculated.

From Sundalagio (the sound between Streymoy and Eysturoy) eastwards it is rather common for individual flows below the Chorizon level to form prominent features in the terrain. Between Nøvin, north of Oyri, and Reyðafellstindur the horizon basalt flows are transected by the large Eysturoy sill. The course of the Chorizon in the northern part of Eysturoy is best seen in fig. 34 (Blámannsfjall, Nón, Vađhorn, Slættaratindur, Gráfelli, Middagsfjall and Tyril seen from Húsafjall), fig. 35 (Middagsfjall, Gráfelli, Sandfelli seen from Tyril) and fig. 36 (Mannssetur-Gráfelli). Its course can also be seen in the area north and west of Fuglafjørour in fig. 37, (the north side of Jøkladalur seen from Gjógvará). In the southernmost part of Eysturoy it was very difficult to map the C-horizon, since the horizon flows are atypical, are very much covered by loose soil and are sometimes lacking completely.

In the northern islands the C-horizon is rather prominent in the terrain over considerable distances (fig. 38). In the northernmost part of Kallsoy and in the northernmost part of Viðoy the presence of the horizon basalt is so uncertain that the boundary has been drawn with a dotted line. In the steep north-facing cliffs the boundary: middle basalt series - upper basalt series is sometimes distinct and sometimes rather indistinct. On the north end of Viðoy, where it is normally not particularly easy to see the boundary in the cliff, it is quite distinct at Enniberg and north of Eiðsvík. On the south side of Viðoy and on the opposite side of Hvannasund, on Borðoy, the boundary: middle basalt series - upper basalt series is very prominent, despite the fact that the presence of the horizon basalt itself is somewhat in doubt, since locally, just below the C-horizon level, there is a series of flows of the same type as the horizon basalt. 


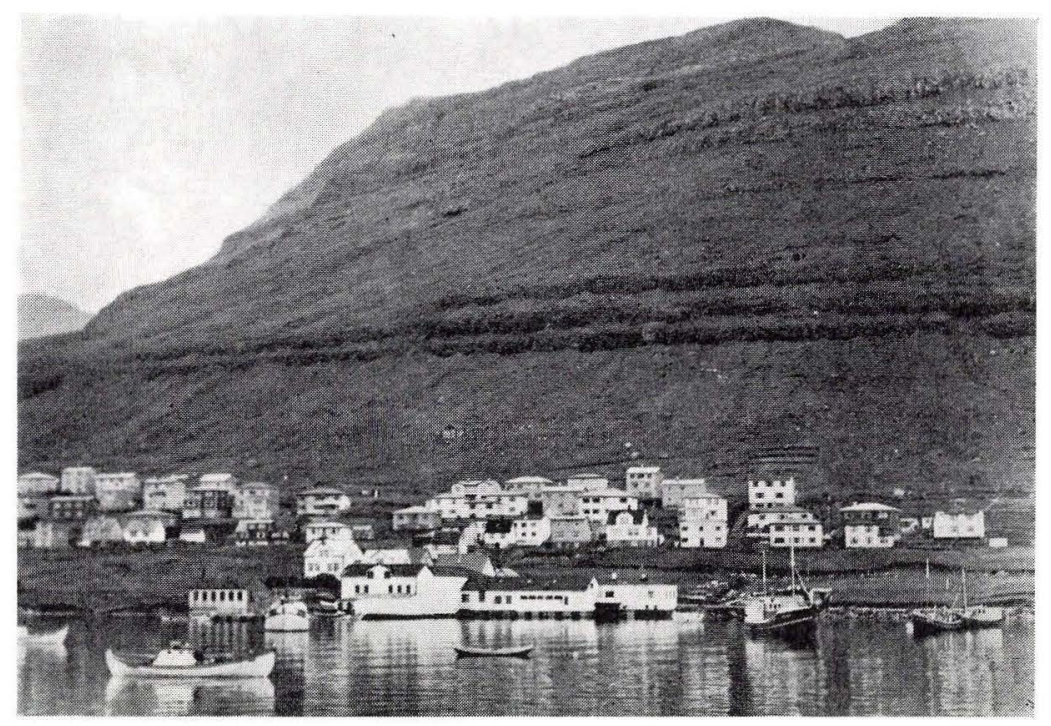

Fig. 38. The C-horizon flows at Klakksvik.

The flow thicknesses in the upper basalt series are in general less than in the lower basalt series, but are nevertheless considerably greater than the flow thicknesses in the middle basalt series. Measurements of 15 flows on Kirkjubøreyn in the southern part of Streymoy gave an average thickness of about $9 \mathrm{~m}$; measurement of 13 flows on Villingadalsfjall in the northern part of Viðoy gave an average thickness of about $8 \mathrm{~m}$. Counting of flows in the vertical cliff on the east side of Svínoy (Eysturh $\varnothing v d i, H \varnothing v d i n$, Áarberg) and division of the cliff height by the number of flows at this locality gave an average figure ranging from $10 \mathrm{~m}$ to somewhat over $11 \mathrm{~m}$. It is clear that these last figures may well be somewhat high; it is not always possible to include the highest flows, and welded scoriaceous horizons and tuff beds have been included because they cannot be distinguished at a distance. A profile along Stórá up towards Knúkur (Svínoy) 340-455 m gave a similar result, $10.5 \mathrm{~m}$; intercalated tuff beds and welded scoriaceous horizons have also been included here. In general, it can be said that the flow thickness in the upper part of the series lies between $5 \mathrm{~m}$ and $10 \mathrm{~m}$ but may be less or greater. In the lower part of the series it is not unusual for the flow thickness to be greater than higher up. For example, the area around Tórshavn consists of 
thick flows of feldspar basalt (Walker and Davidson: "Torshavn type"), of which one that runs alongside the harbour is about $30 \mathrm{~m}$ thick. Lava flows resembling those of the middle series can sometimes be seen in the upper basalt series; such flows are particularly clear in the northern islands. Flows of compact, blue basalt terminate by becoming gradually thinner and thinner while the more viscous feldspar basalt flows on the other hand terminate abruptly with a blunter type of wedging-out. On the west side of Borðoy several "lamellated series" of this type can be seen; on the east side of the island they unite, the intervening flows thinning out in an easterly direction.

The individual flows in the upper series are normally clearly separated from each other by welded scoriaceous horizons and tuff, apart from the intercalations of lavas of middle series type ("laminated series") mentioned previously. Columnar structure occurs, but is generally weak and irregularly developed. Flow structure is clearest in flows of compact, blue basalt.

The interbasaltic deposits comprise mainly tuff and tuffaceous clayey sediments. The tuff beds vary considerably in thickness, consistency and in colour. Their thickness normally varies from fractions of $1 \mathrm{~m}$ to $3-4 \mathrm{~m}$, their consistency from fine-grained and firm to sandy and more friable, and the colour from yellow through brownish to bright red, occasionally greenish. The tuff contains not uncommonly scattered faint impressions of indeterminable plant remains, for example a tuff bed below the NW-SE trending basalt escarpment in Húsahagi about $1.5 \mathrm{~km}$ from the town of Tórshavn, where impressions have been found, probably of a Sequoia branch (Noe-Nygaard 1940). The tuffaceous clayey sediments often achieve considerable thicknesses, not infrequently about $10 \mathrm{~m}$; they also vary in consistency and colour. Several of these tuff-clay sections have been worked previously for export, in particular a sedimentary sequence at Hósmøl on Nólsoy, one on the south end of Sandoy and, to a lesser extent, a sedimentary sequence north of Skálavik on Sandoy.

As an example a profile through the tuff-clay sequence at Hósmøl, Nólsoy will be given. The profile was measured just inland from Flesin á Hósmøl (fig. 39): 


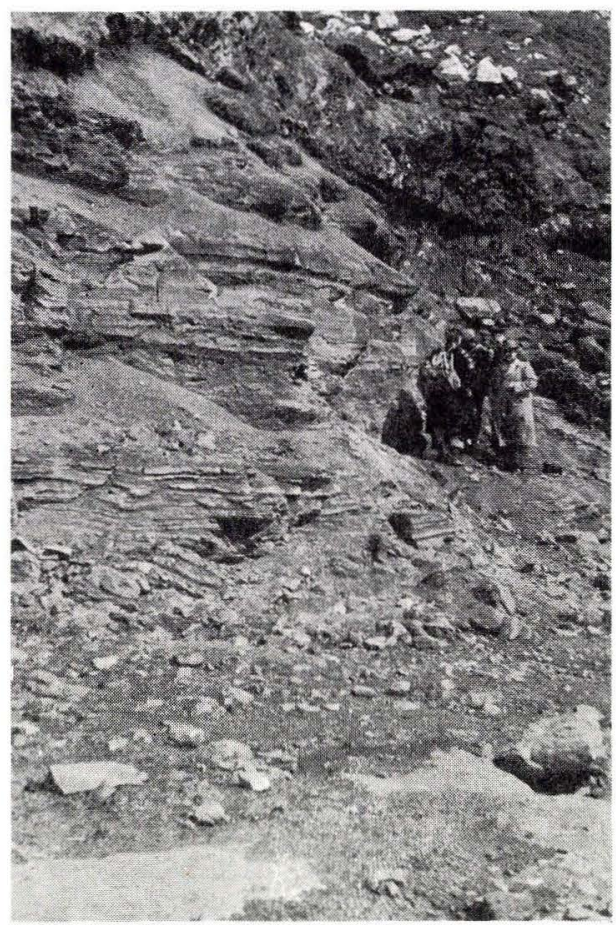

Fig. 39. Tuff-claystone sequence at Hósmøl, Nólsoy.

Overlying rock: Basalt flow, 3 m thick.

$350 \mathrm{~cm}$ : Predominantly ochre-coloured clay, permeated in all directions by small cracks, most of which have a brown coating.

$185 \mathrm{~cm}$ : Predominantly yellowish clay of the same consistency. In the upper part are some darker bands.

$85 \mathrm{~cm}$ : Cliff-forming greyish-black sediment, which breaks up into sharp fragments; the rock consists of much coarser material than the above and is almost sandy or gritty in character.

$60 \mathrm{~cm}$ : Alternating light-brown to ochre-coloured and yellow tuff-clay beds.

$10 \mathrm{~cm}$ : Hard, coarse, reddish-violet bed with incrustations of zeolitic material.

$80 \mathrm{~cm}$ : Alternating light-brown to ochre-coloured and rather light, yellowish beds. 
$10 \mathrm{~cm}$ : Hard, coarse, reddish-violet bed with incrustations of zeolitic material.

$36 \mathrm{~cm}$ : Alternating brownish and yellow-green tuff-clay beds.

$68 \mathrm{~cm}$ : Hard, light-brown shale containing a few greenish, coarser-grained beds.

Above this sequence, but separated from it and from each other by basalt flows there are another two sequences of similar type and thickness; the base of the lower sequence reaches the sea just south of Flesin á Hósmøl, the base of the middle sequence about $500 \mathrm{~m}$ farther south and that of the upper sequence about $650 \mathrm{~m}$ farther south again. On the east side of the island the base of the lower sequence reached the sea about $500 \mathrm{~m}$ south of Bólstaðtangi, that of the middle sequence about $700 \mathrm{~m}$ farther south and that of the upper sequence about $600 \mathrm{~m}$ farther south again. The lower sequence lies at a height of about $100 \mathrm{~m}$ above the path, which runs southwards from Nólsoyarbygd up across the island.

The sedimentary sequence in the southern part of Sandoy has been mined at the village of Dalur and at Dalsnípa. The succession from the bottom up is as follows: brown tuff, grey-brown tuff, red or reddish-brown tuff. The thickness of the three beds is on the basis of an average of 6 measured profiles, $142 \mathrm{~cm}, 30 \mathrm{~cm}$ and 250 $\mathrm{cm}$ respectively. Only the lowest brown tuff has been utilized.

Yet another tuff-clay sequence of considerable thickness can be mentioned. It lies on the south-east side of Hálgafelli on Borðoy at a height of somewhat over $420 \mathrm{~m}$; it is about $8 \mathrm{~m}$ thick; the colour is light yellow at the base, becoming more brownish upwards, and is light reddish at the top. The rock, which on the whole is rather coarse-grained, contains thin pebbly beds. It may be the same series that can be seen in Kunoyarnes at a height of about $510 \mathrm{~m}$, where the thickness is also about $8 \mathrm{~m}$, and in Gøtunestindur in Eysturoy at a height of about $460 \mathrm{~m}$, where the thickness is 6-8 m.

The olivine-bearing basalts of the upper series are dark, bluishblack rocks, which are hard and tough. They often have platy fracture and smooth fracture surfaces. Lenticular zeolite-filled amygdules are common. Most of these lavas carry a certain number of phenocrysts of plagioclase and olivine. The olivine is easily visible 
in the field. The groundmass texture can be intergranular, but subophitic and ophitic textures dominate.

Magnesium-rich olivine is the dominant phenocryst mineral, and is generally fresh. In some cases the olivine has thick, opaque borders. In a few cases olivine is only in the groundmass; its iron content is then somewhat higher than usual.

The clinopyroxene is an augite. Pigeonite has not been found in the groundmasses.

The phenocryst plagioclases are bytownitic in composition, with $84 \% \mathrm{An}$ as an average in the cores and $64 \% \mathrm{An}$ in the outer zones and in the groundmass.

Most of the ore grains are small and equidimensional; they are not as numerous as in the porphyritic and aphyric rock types. The olivine-bearing basalts are almost devoid of glass, and green alteration products are generally absent.

Olivine-bearing basalts intercalated with the porphyritic lavas at lower levels in the middle series are very similar to those described above.

The average mineral composition of the olivine-bearing lavas, olivine tholeiites, from the upper series is:

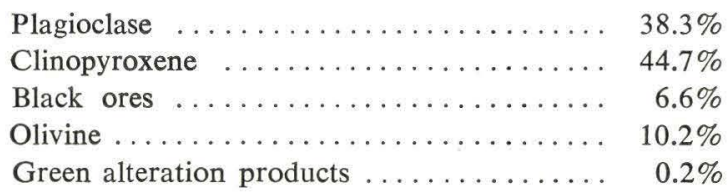

(Chemical analyses are given on pp. 226-227 in the Memoir.) 


\section{Minor intrusions}

When the extrusive volcanism was over and the basalt plateau had been formed, settling or subsidence in the underlying support gave rise to tensions in the plateau with consequent formation of fractures, so that the magma once more, as a terminal phase of the volcanic activity, rose and intruded the plateau itself. The intrusion took place partly along vertical fractures (lamellar zones), giving rise to dykes, partly in the coal-bearing sequence and the tuff agglomerate zone, i.e. between the lower and middle basalt series, giving rise to the irregular intrusive bodies and finally in the boundary zone between the middle basalt series and the upper basalt series, giving rise to sills.

\section{Dykes}

Dykes are formed by the intrusion of a magma into vertical or steeply inclined fractures in the crust. When the magma solidifies the dykes form elongated, plate- or lens-shaped bodies, which transect the structure of the surrounding normally deposited rocks (fig. 40).

Dykes can be single, multiple or composite. A single dyke is the result of a single magma intrusion, a multiple dyke is the result of two or more intrusions of the same type of magma, and a composite dyke is the result of two or more magma intrusions, with various types of magma.

The dykes permeate the whole of the Faeroese basalt plateau and were intruded in a system of fracture or lamellar zones, whose time of formation was before the intrusion of the dykes (see p. 133).

The dykes are usually straight, somewhat curved or gently sinuous; to some extent this depends on how strong or weak the resistance was that the particular zone of weakness (lamellar zone), offered. Not infrequently the course of a dyke is somewhat irregular because the magma during the intrusion met so much resistance that it penetrated along the sides where the resistance was less. 


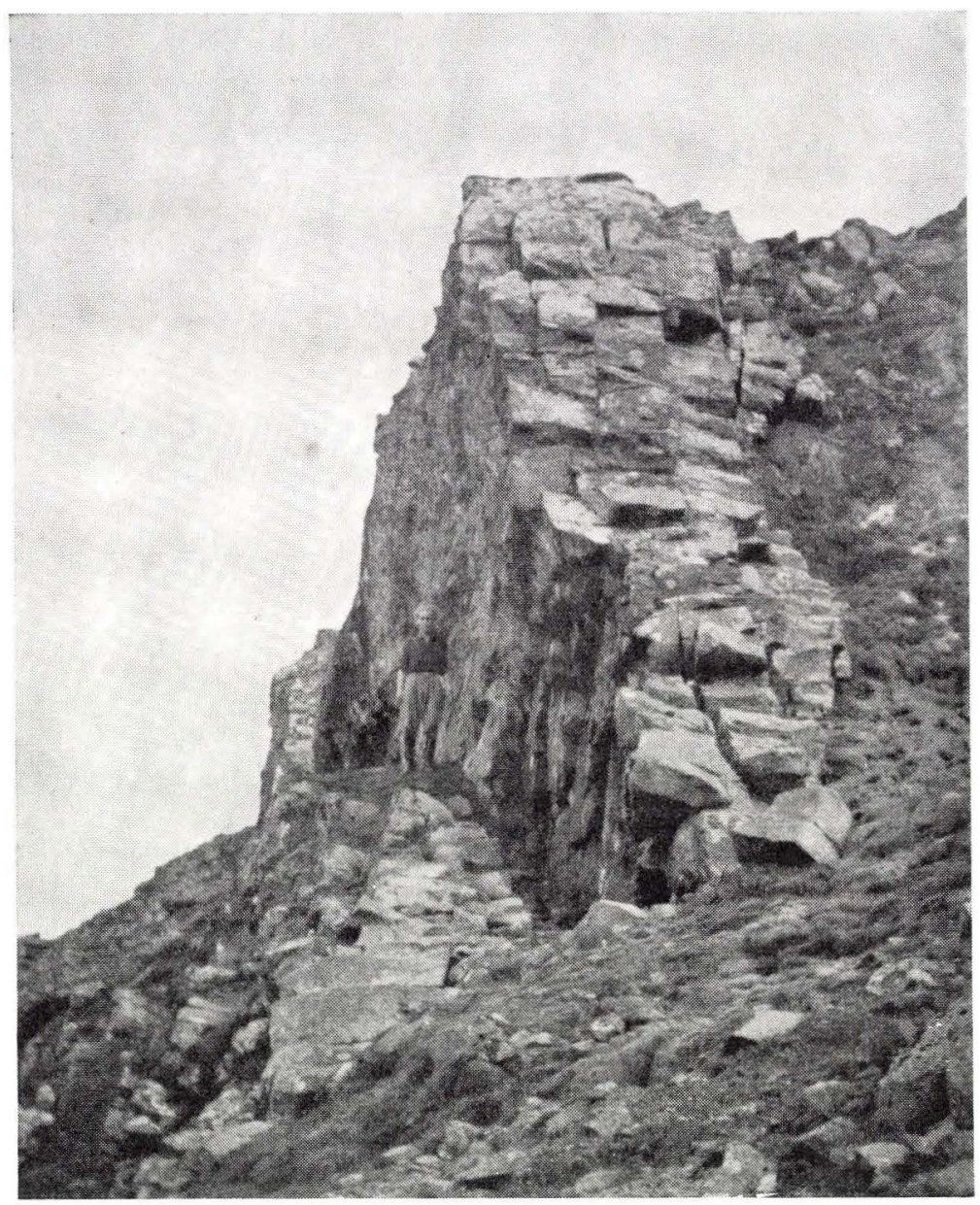

Fig. 40. Dyke on Postulakirkja, north of Vestmanna.

Examples can also be seen where a dyke changes direction completely and continues in a lamellar zone crossing the first.

If one observes dykes in bare vertical cliffs, one can see that the dykes are predominantly vertical, but a slight deviation from the vertical is not uncommon. Inland, possibilities for observing the dykes are limited, since much of the terrain is covered by loose glacial deposits, bogs and weathered material. Observations here are therefore frequently fragmental, and it is rather difficult to correlate the individual dykes with certainty. The symbol for dykes on the geological map therefore generally indicates observations of 
individual exposures of dykes; a continuation of the dyke symbol beyond the observed exposure has only been made when it was considered to be completely justifiable. The individually observed dyke exposures, or occasionally several dyke exposures that can be correlated with certainty, have been given Arabic numerals in italics on the map.

The total of dyke exposures observed amounts to 845, and these are distributed over the individual islands as follows: Fugloy 14, Svínoy 13, Viðoy 25, Borðoy 74, Kunoy 47, Kallsoy 51, Eysturoy 207, Streymoy 231, Nólsoy 3, Sandoy 8, St. Dímun 1, Sưuroy 53, Hestur 3, Koltur 4, Mykines 2 and Vágar 109.

As mentioned, the dyke symbol on the map represents dyke exposures. Up till now no dyke has been observed that was exposed throughout the whole of its length, but in several cases a correlation of several exposures can be made with considerable certainty over a shorter or longer distance, since both dykes and lamellar zones can often be traced in the terrain as more or less distinct lineaments. However, one has to be careful not to draw too far-reaching conclusions from this since it was often observed that a lamellar zone continues as a lineament in the terrain after the dyke has thinned completely out or after a dyke has suddenly changed direction.

By linking up individual exposures it was thus possible to trace dykes for distances of up to $21 \mathrm{~km}$.

Amongst the dykes with a length of between 10 and $21 \mathrm{~km}$ mention can be made of the dyke that run from south of Egilsnes, to the south of Vestmanna, as far as Trantur, north of Skælingur, (Str. 182, 183, 197, 198, 199, 200, 221, 216 and 215), which is about $10.5 \mathrm{~km}$ in length. The rock is a plagioclase-porphyritic basalt with large plagioclase laths oriented parallel to the length of the dyke. The dyke follows a lineament that is not entirely straight in the terrain; towards the south it is interrupted by the large Streymoy sill, and the surface of the sill in the interval between the two parts of the dyke is clearly lamellated. While south of Egilsnes the dyke (Str. 182) is interrupted to the north-west by Vestmannasund, its natural termination to the south-east can clearly be seen in the gjógv up towards Trantur (Str. 215). It becomes reduced in thickness here; at a height of $420 \mathrm{~m}$ its breadth is just over $4 \mathrm{~m}$ and at $560 \mathrm{~m}$ just over $1 \mathrm{~m}$. After this it peters out in thin, irregular 
apophyses. At the same time the feldspar phenocrysts decrease in both size and number.

The dyke running from south of Ljósá to Oyndarfjørour (Ey. $172,178,181,19,20,22,26)$, is about $10.8 \mathrm{~km}$ long and has a curved course. The rock is a compact, blue basalt.

The dyke running from Djúpidalur to Hvalvík (Str. 112, 118, $150,151,152)$ is about $11.5 \mathrm{~km}$ long. Its course is slightly curved. The rock is a compact, blue basalt.

The dyke running from Dalagjógv to Sundalagio (Str. 104, 110, $61,60,69,49,79,78$, Ey. 173) is about $12 \mathrm{~km}$ long and has an almost straight course. It consists of compact, blue basalt.

The dyke running from Trogará (Eysturoy) to north of Knúksdalur (Kallsoy) (Ey. 174, 192, 191, 186, 51, 49, 48, 34, 33, 32, 31 , Ka. 31, 27), is about $19.5 \mathrm{~km}$ long. Its course is curved. The rock is compact, blue basalt.

The dyke in the southern Glyvursgjógv (Str. 82, 99, 102, Ey. $196,197,59,87,88,98)$ is about $19.7 \mathrm{~km}$ long. It has an approximately straight course from Gøtugjógv as far as the southern Glyvursgjógv, then curves southwards across Saksunardalur and continues as a lineament in the terrain (lamellar zone) about 5.5 $\mathrm{km}$ as far as Grótdalsgjógv south of Saksun. The dyke consists of compact, blue basalt.

The dyke running from Tvørgjógv (northern Suðuroy) to the south side of Hovsfjørour (Su. 1, 2, 9, 10, 11, 27, 28, 29, 30, 40) is about $21 \mathrm{~km}$ in length. Between Úlvsgjógv (Su. 9) and Knúkaborg (Su. 11) a horizontal displacement of the dyke in the terrain can be seen. Between Tvørgjógv and the north side of Hovsfjørður the dyke has a width of $8-12 \mathrm{~m}$, while on the south side of Hovsfjørður, which is the last place it was observed towards the south, it is only $1 \mathrm{~m}$ wide; it consists of compact, blue basalt.

At all the places where the termination of a dyke was observed it was noted that the dyke becomes reduced in thickness quite suddenly and peters out in irregular thin apophyses (e.g. B. 63, Ey. 149, Str. 215, Su. 37), but since such a termination has never been observed at both ends of one dyke it is impossible to say anything definitely about the original maximum length of the dykes.

The dykes vary in width from fractions of $1 \mathrm{~m}$ to about $20 \mathrm{~m}$. The greatest dyke width, about $20 \mathrm{~m}$, was observed at the landing place in Sunnba (Su. 50). 
Of 535 dykes distributed over the whole plateau and in all three basalt series, one dyke is $20 \mathrm{~m}$ wide, 19 dykes are in the range $10-15 \mathrm{~m}, 110$ dykes are in the range 5-10 $\mathrm{m}$ and the rest (405 dykes) are less than $5 \mathrm{~m}$ in width. The average width of all these dykes is about $4 \mathrm{~m}$.

If the lower and the upper basalt series are considered separately, dykes in the lower basalt series (35 in all) show a width of $4.9 \mathrm{~m}$ and dykes in the upper basalt series (116 in all) show an average thickness of $3.8 \mathrm{~m}$.

It has never been seen that a dyke spreads out laterally and continues as a lava flow, but on the other hand several cases were seen (e.g. Sv. 4, Við. 23, B. 21) where a dyke thins out upwards and peters out in apophyses in the same way as dykes have been seen to terminate laterally in the terrain.

If a dyke is more resistant to erosion than the country rock, it will stand up above the terrain as a wall or a ridge. The bestknown example in the Faeroe Islands is Jatnagarđar on Vágar (Vá. 17, 18).

If the dyke is less resistant than the country rock a gully will be formed (Faeroese giógv). Steep-walled, deep, long gullies of this type (Faeroese gjáir) are a notable morphological feature in the Faeroese landscape. These widely occurring gullies make it possible to study the intrusion of the dykes more closely since we find exposures of the sides of the dykes and of the vertical walls of the country rock.

Because of contraction during the solidification of the magma the dykes always have a more or less pronounced columnar structure. The columns are oriented at right angles to the walls, which have acted as cooling surfaces. Since the adjustments to tension in the plateau, which were the cause of the formation of the lamellar zones, have often been active after dyke intrusion, there is often a distinct jointing of the dyke along its length. This jointing can be so extensive that the basalt in the dyke has been broken up into narrow lamellae parallel to the length of the dyke (fig. 41). Between the lamellae there are often veins of calcite, zeolites or fuller's earth (montmorillonite).

Even if the rock in one and the same basalt dyke is rather uniform the difference in grain size is however prominent if a comparison is made between the centre of the dyke and the margin, where moreover a clear heat effect can sometimes be traced in the 


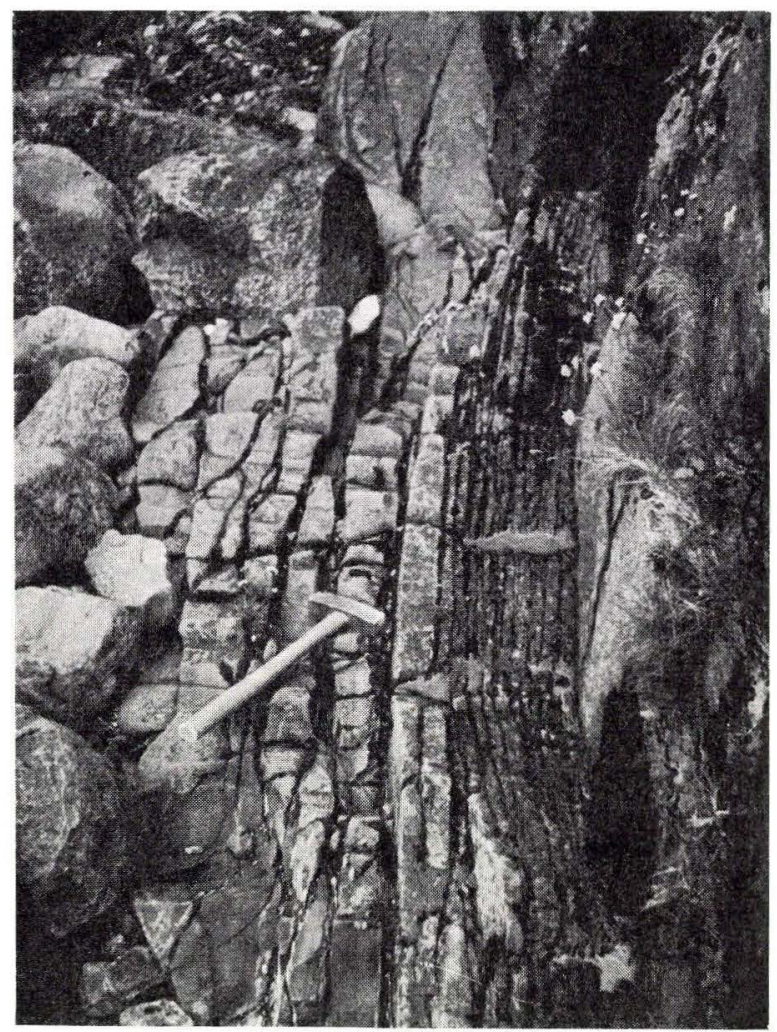

Fig. 41. Lamellar dyke and wall rock, north-east of Tórshavn.

wall rock. A marked difference can also be seen in the character of the rock towards the termination of a dyke, where it thins out and peters out in apophyses, e.g. Str. 216, which consists of largegrained feldspar basalt with plagioclase laths, the feldspar phenocrysts decreasing greatly in size and number in the rock forming the apophyses (Str. 215).

While the thin apophyses that represent the upwards and outwards termination of a dyke are "dyke apophyses", since they are intruded in the vertical lamellar zones, which often continue with the same direction as the dyke, it is possible to see at the sides of the dyke or in the wall rock apophyses that are "sill apophyses", since they are intruded laterally in weakness zones (tuff beds, vesicular or zeolitic zones) between the individual basalt flows in the wall. In olivine-porphyritic basalts sinking of olivine grains can often be 
observed in these sill apophyses; the olivine grains are sparse in the upper part of the apophyses, while in the lower part they have attained a marked concentration (Noe-Nygaard 1945).

No dykes are known that have a composition other than basaltic and the dyke types are not very different from the types we know from the lava flows. As main types they can be described macroscopically as follows: 1 . Compact, bluish basalt, hard and without phenocrysts. 2. Porphyritic basalt with small plagioclase phenocrysts. 3. Porphyritic basalt with large phenocrysts and 4. "Olivine basalt" with a considerable number of microscopically visible olivine grains.

The distribution of these types on the basis of 513 samples is as follows: Compact, blue basalt 391 or $76.2 \%$, plagioclase-porphyritic basalt 62 or $12.1 \%$, big-feldspar basalt 33 or $6.4 \%$ and "olivine-basalt" 27 or $5.3 \%$. It can be seen from this that the compact, blue basalt is by far the dominant dyke type.

The overwhelming majority of the dykes are single dykes. However, there are both multiple dykes and composite dykes.

As an example of a multiple dyke mention can be made of the dyke that crosses the western tributary of the Hala stream south of Hvalvík at a height of about $300 \mathrm{~m}$ (Str. 162). It consists of two intrusions. The western dyke is about $10 \mathrm{~m}$ wide and the eastern dyke about $1.5 \mathrm{~m}$ wide. The dyke rock is compact, blue basalt. Judging from the contact relations the eastern dyke was intruded last. The dyke can be seen again towards the south-east at the eastern tributary of the Halá stream at a height of about $360 \mathrm{~m}$ (Str. 163) and towards the north-west at Hvalvíksgjógv at a height of about $230 \mathrm{~m}$ (Str. 153). At Hvalvíksgjógv (Str. 153) a thin medial lamella can be seen, which consists of plateau basalt. The dyke east of the medial lamella is only about $1 \mathrm{~m}$ wide and the dyke west of the medial lamella is about $12 \mathrm{~m}$ wide. At the eastern tributary of the Hala stream (Str. 163) two separate dykes can be seen with about $5 \mathrm{~m}$ between them. The eastern dyke here is about $1.5 \mathrm{~m}$ wide and the western dyke about $2 \mathrm{~m}$ wide.

As examples of composite dykes mention can be made of a dyke at the coast in Syoradalur on Kallsoy (Ka. 28) and a dyke on the shore west of Lygnnes, Kollafjørður (Str. 11).

The dyke in Syoradalur (Ka. 28) runs through a gjógv trending approximately ENE-WSW. The northern dyke is about $4 \mathrm{~m}$ wide. It consists of compact, blue basalt. The southern dyke is $5-5.5 \mathrm{~m}$ 
wide and consists of plagioclase-porphyritic basalt. The dykes are separated by a lamella of wall rock about $1 \mathrm{~m}$ wide. The dyke is probably the same as that which runs in Hvalgjógv on the southwest side of Kunoy (Ku. 25), on the eastern side of Kallsoyarfjørour, but here the situation is reversed since the northern dyke consists of plagioclase-porphyritic basalt and the southern of compact, blue basalt. In Hvalgjógv there is also a medial lamella about $1 \mathrm{~m}$ wide. The total width of the dyke is about $10 \mathrm{~m}$. The two dykes must therefore be presumed to intersect and to "change places" below the water.

The dyke west of Lygnnes, Kollafjørdur (Str. 11), can be seen exposed on a flat shore section. The total width is about $4.40 \mathrm{~m}$. Starting from the west we find: $1.20 \mathrm{~m}$ compact, blue basalt, 1.50 $\mathrm{m}$ feldspar-porphyritic basalt with large plagioclase laths oriented in the direction of the dyke and thereafter a further $1.70 \mathrm{~m} \mathrm{com-}$ pact, blue basalt. Towards the wall rock (a vesicular, zeolite-bearing basalt), on both the west and east sides of the dykes, a finegrained contact can be seen; the feldspar-porphyritic dyke in the middle shows a glassy contact with the compact, blue basalt on both sides. The feldspar-porphyritic dyke must therefore be the younger and must have been intruded in an older, already cooled dyke of compact, blue basalt.

Because of adjustments to tension in the plateau with formation of lamellar zones after the dyke intrusion (see p. 133) the dykes are often closely lamellated along their length and are sometimes brecciated. Intersecting dykes can often be seen to be horizontally dislocated along the younger lamellar zone. A horizontal dislocation of this type affecting a dyke can often be seen where a lamellar zone without intrusion crosses a dyke. The amount of displacement varies greatly, from less than $1 \mathrm{~m}$ up several metres. The greatest horizontal displacement of a dyke observed - about $100 \mathrm{~m}$ - was at Rangagjógv (Str. 27) and Lundagjógv (Str. 36), both of which trend roughly ESE-WNW on opposite sides of the bay at Tjørnuvík, on the north end of Streymoy.

Particularly strong dislocations occur around Dalagjógv-Djúpadalsgjógv, north of Vestmanna, and along the WSW-ENE trending movement zone from Dalagjógv across Saksunardalur.

The area Dalagjógv - Djúpadalsgjógv. The dyke in Dalagjógv (Str. 105, large-grained feldspar basalt) and the dyke in Djúpadalsgjógv (Str. 112, compact, blue basalt) are crossed by two dykes trending 
approximately NW-SE, Str. 113, 114, 106, 107 (olivine basalt) and Str. 115, 116, 108, 109 (feldspar basalt). In the area between Dalagjógv and Djúpadalsgjógv these last two dykes are displaced towards the west, the displacement along Dalagjógv being about $10 \mathrm{~m}$ and the displacement along Djúpadalsgjógv being about $40 \mathrm{~m}$. At Giljar, east of Dalagjógv, the dyke Str. 61 (compact, blue basalt) is crossed by two dykes, Str. 64, 65 (feldspar basalt) and Str. 62, 63 (olivine basalt). South of the Dalagjógv zone these two dykes are also displaced about $10 \mathrm{~m}$ towards the west.

If we follow the movement zone from Dalagjógv farther towards the east-north-east we find the same pattern at Saksunardalur around the northern and southern Glyvursgjógv.

The area at Glyvursgjógv, Saksunardalur. The dyke in the northern Glyvursgjógv (Str. 49, compact, blue basalt) is crossed by three dykes: Str. 50, 51 (compact, blue basalt), Str. 52, 53 (compact, blue basalt) and Str. 80, 81 (compact, blue basalt). South of the gjógv all these dykes are displaced about $18 \mathrm{~m}$ towards the west. The dyke in the southern Glyvursgjógv (Str. 82, compact, blue basalt) is crossed by two dykes: Str. 83, 84 (compact, blue basalt) and Str. 85, 86 (compact, blue basalt). North of the gjogv these two dykes are displaced about $55 \mathrm{~m}$ towards the west. As in the area between Dalagjógv and Djúpadalsgjógv the whole area between the northern and southern Glyvursgjógv is displaced towards the west.

In Dalagjógv, Giljar, and the northern Glyvursgjógv the floor of the gjógv and the dyke material in it are brecciated and closely lamellated in the trend direction of the giógvs, but despite the fact that this is one almost straight lamellar zone, the intrusion material is not the same. While the intrusion material in the northern Glyvursgjógv (Str. 49) and in Giljar (Str. 61) is compact, blue basalt, the intrusion material in Dalagjógv (Str. 105) is largegrained feldspar basalt. It is probable that in the area between Dalagjógv and Giljar the dyke bends and that there is an intersection, the dyke from Dalagjógv (Str. 105) changing direction and continuing eastwards up into Havursgjógv (Str. 67, large-grained feldspar basalt), and the dyke from northern Glyvursgjógv and Giljar continuing south of Dalagjógv to Str. 110 and 104.

The area Ravnagilsá, Saksunardalur. The dyke in the gjógv at Ravnagilsá (Str. 87, large-grained feldspar basalt) is crossed by three dykes, Str. 88, 89 (compact, blue basalt), Str. 90, 91 (com- 
pact, blue basalt) and Str. 92, 93 (compact, blue basalt). On the north-west side of the giógv at Ravnagilsá these three dykes are displaced about $20 \mathrm{~m}$ towards the north-east. The dyke in the gjógv at Ravnagilsá (Str. 87) intersects the dykes crossing the gjógv and thus belongs to a younger dyke generation, as do some other feldspar-porphyritic dykes observed.

The area Ljóságjógv, Skipagjógv, Funningsfjфrður. If we follow the Dalagjógv zone even farther towards the east-north-east, to Funningsfjørður, we meet once more an area of dyke dislocation between Ljóságjógv and Skipagjógv. The dyke in Olavsøkugjógv (Ey. 177, compact, blue basalt) is crossed by the dyke in Ljóságjógv (Ey. 175, 176, compact, blue basalt). The dyke in Skipagjógv (Ey. 191, compact, blue basalt) is crossed by the dyke Ey. 189, 190 (compact, blue basalt). In the area between Ólavsøkugjógv and Skipagjógv the two intersecting dykes are horizontally displaced about $20 \mathrm{~m}$ and about $26 \mathrm{~m}$ respectively towards the west. On the east side of the fjord an E-W trending horizontal fault zone cuts the dyke Ey. 182, 183 (large-grained feldspar basalt). North of this fault zone the dyke is displaced about $5 \mathrm{~m}$ to the east.

Amongst other localities where horizontal displacements of dykes can be observed are the following: the west side of Skarðsvík (Fu. 2), north of Hvannasund (Við. 13), the west side of Árnafjørður (B. 18), Borðoyarnes (B. 33,35), Sjóvará (Str. 4,5), Tjørnuvík (Str. 28), Skúvadalsgjógv (Str. 132, 133), Norðaragjógv (Str. 188, 189 and 190, 191), Heimaragjógv - Marknagil (Str. 218, 219), Bóndagjógv (Vá. 27), Ørgusgjógv (Vá. 48), Rangagjógv (Vá. 76), Hýsisá (Vá. 87).

In order to see which were the dominant dyke directions the dykes were plotted on rose diagrams and in order to obtain a picture of the variations in direction from one area to another we made rose diagrams for the individual islands or groups of islands separately. In the centrally situated smaller islands the number of dykes is so small that a graphic representation is unneccesary.

If the rose diagrams for Vágar, Streymoy, Eysturoy and the Norðoyar group are compared we find fairly good agreement, with a rather even spread of directions over the whole rose diagram; however, in the Norðoyar group trends lying between NNE-SSW and NE-SW are more prominent, which may be regarded as a natural consequence of the fact that this group of islands is situated farther away to the north-east. On Suouroy the NW-SE trend is 
clearly dominant. If we then compare the rose diagrams for the dykes with rose diagrams for lamellar zones and gjógvs, we find that there is only a slight agreement between the rose diagrams for the dykes and those for the lamellar zones, while there is a remarkably good agreement between the directions of the lamellar zones and those of the gjógvs. (See pp. 246-250 in the Memoir.)

Although the rock types in the dykes are similar to the corresponding lava types in the plateau, there is one marked difference: olivine is more abundant in the dyke rocks.

Only about $10 \%$ of the fine-grained, bluish dyke rocks are wholly devoid of olivine; the majority have single grains of olivine and intergranular texture. With the change to ophitic texture the olivine content rises to about $10 \%$. (Chemical analyses are given on p. 252 in the Memoir.)

\section{Irregular intrusive bodies}

We have used this term to describe this type of intrusion. The irregular intrusive bodies differ from other types of intrusions in their completely unrestricted and irregular form, since their basalts have been intruded into the little-resistant and inhomogeneous material that makes up the tuff-agglomerate zone. The irregular intrusive bodies occur everywhere within and along this zone, and are intruded in it and in the transition zone between the coalbearing sequence and the tuff-agglomerate zone. They therefore only occur on the north-eastern side of Suðuroy, on Tindhólmur and in the north-western part of Vágar (see p. 64).

\section{Sиðиноу}

The irregular intrusive bodies have only been briefly mentioned in older literature. Forchhammer (1824) mentions "irregular basalt" from Tjørnunes (Kjødenæs), on the south side of Hvalbiarfjørður, to Hvannhagi (Quönnahea), on the north-east side of Suðuroy, and states that the coals in Hvannhagi must have been "torn loose and raised up" (translation) since on the basis of the general strike they should not occur here. Trevelyan (1823) who travelled throughout the Faeroe Islands together with Forchhammer, also mentions intrusive basalt, "columnar basalt", at Tjørnunes. Geikie 
(1880) mentions "intrusive basalts" along the coast from Hvannhagi (Kvanhauge) to Tjørnunes (Tiødenenes) and on the north side of Hvalbiarfjørður, and considers that they probably all belong to the same intrusive body. He mentions, just as Forchhammer, that the coals in Hvannhagi are dislocated. Helland (1880) and B $\emptyset$ ggild $(1922,1928)$ only touch briefly on these features. Geikie (1880) and Bøggild (1928) regard the columnar basalts along the shore at Froðba as being intrusive, which conclusion has never been substantiated by later investigations. In recent years the irregular intrusive bodies have been dealt with by Rasmussen (1952 and 1957).

On the north side of Hvalbiarfjørður intrusive basalts can be seen along most of the coast section from the old landing place as far as Reyðibarmur. At the small bay west of the landing place apophyses and remnants of chilled marginal rock mark the western limit of the intrusion, and immediately west of the landing place this forms the foundation for the jetty and the warehouse. It is visible again east of the landing place, where it occupies the whole of the foreshore; farther out it increases in thickness and forms a steep cliff, whose height midway between the western landing place and the new quay is about $10 \mathrm{~m}$. Thereafter it becomes reduced in thickness; in the small bay west of Hamranes the upper boundary of the intrusive basalt is situated at a height of $35 \mathrm{~m}$; the height of the coast profile itself here is about $20 \mathrm{~m}$.

From Hamranes the thickness seems to become less out towards Reyðibarmur. The coastal stretch from the landing place to the west side of Reyðibarmur is about $1,200 \mathrm{~m}$. On the west side of Reyðibarmur the contact zone between the intrusive basalts and the tuff-agglomerate zone is exposed, and at Reyðibarmur itself the tuff-agglomerates are underlain by intrusive basalts, from which there are frequent irregular apophyses up into the tuff-agglomerates.

Between Hamranes and Hvítanes a dyke can be seen in the coast. It cuts the intrusive basalt, the tuff-agglomerate zone and the middle basalt series. It trends NW-SE and can be followed at intervals from Tvørgjógv, on the north side of the island, to the south side of Hovsfjørður (Su. 1, 2, 9, 10, 11, 27, 28, 29, 30, 40) - in all a distance of about $21 \mathrm{~km}$. The width of the dyke varies from 8 to $12 \mathrm{~m}$; on the north side of Hvalbiarfjørour it is about $8 \mathrm{~m}$. In the coast between Hamranes and Hvítanes, where the dyke cuts the intrusive basalt mass, the dyke does not exhibit any sharp 
contact to the sides, even though some thermal effects can be traced in the contact zone itself. It is not typically columnarjointed, and no clear difference can be seen in grain size from the middle of the dyke towards the contact zone. In the boundary area up against the dyke, columns oriented roughly horizontally can be seen, which farther away attain a vertical position. Farther up in the gully, where the dyke runs in the lavas of the middle basalt series, columnar structure is better developed, with sharp-edged columns; moreover, a sharp contact can be seen here with the country rock, and a considerable difference can be seen in grain size between the middle of the dyke and the contact zone. There can therefore hardly be any doubt that the dyke and the intrusive basalts at the coast were formed roughly simultaneously, and that the dyke may have been a feeder for these.

On the south side of Hvalbiarfjørður intrusive basalt can be seen at Flekksá about $60-100 \mathrm{~m}$ above sea level; intrusive basalt also occurs locally in the coast out towards Tjørnunes and farther east as far as Myrkagjógv; Tjørnunes itself consists entirely of intrusive basalt. Here it can be observed directly that the coalbearing sequence is cut by the intrusion.

In Lónin bay the irregular intrusive basalt is situated at the coast. Hvannhólmur, the small islands on the landward side and the other islands and skerries at Lónin are composed of basalt columns of intrusive origin oriented in various directions. The intrusive basalt can be followed farther south along the coast into Hvannhagi. Hvannhagi is largely covered by vegetation, but the intrusive basalts can however be seen exposed along the coast between Todnes and Stapin, and locally to the south through the whole of Hvannhagi and along the coast eastwards towards Ribbingamúli (fig. 20). Locally they attain considerable thickness, for example in the southernmost part of Hvannhagi, where they can be seen along the shore and can be traced upwards to a height of about $60 \mathrm{~m}$. Towards the west in this area they lie above the coalbearing sequence. As first mentioned by Forchhammer (1824) the coal-bearing sequence, which dips north-east and cuts sea level at Kolaratangi, Tjørnunes and Froðbiarnípa must be dislocated, since it is visible near the coast at Hvannhagi and Lónin. Further evidence of dislocation associated with emplacement of the irregular intrusive basalts can be seen at Stapin, where we find remains of the coal-bearing sequence strongly dislocated and included in the in- 


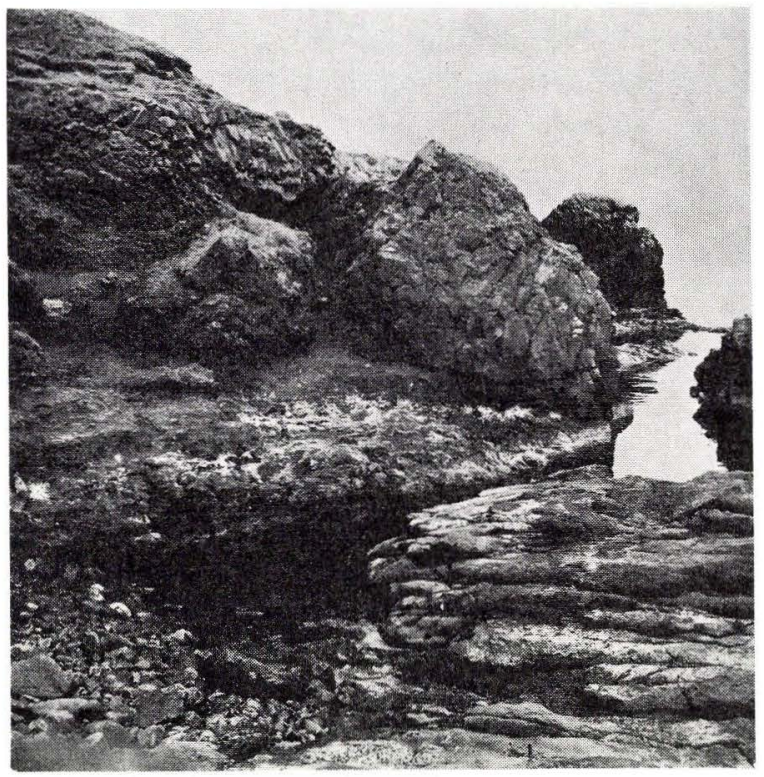

Fig. 42. Intrusive basalt containing dislocated coal seams. Agglomerate in the foreground. Near Stapin, Suðuroy.

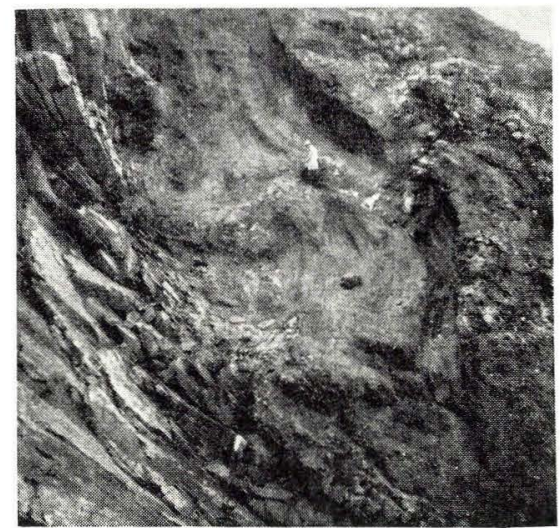

Fig. 43. Sedimentary strata ("basaltic sandstone") incorporated in intrusive basalt. North of Stapin. 
trusive basalts (fig. 42), and between Stapin and Todnes, where a 4-6 m wide and approximately $30 \mathrm{~m}$ long vertically dipping sedimentary sequence consisting of "basaltic sandstone" also forms an inclusion in intrusive basalt (fig. 43). The original attitude of the sedimentary sequence is shown by sun cracks on its eastern side. In the middle of Hvannhagi the intrusive basalt can be seen at Dysjarnar, partly covered by landslide. It can also be followed from about $20 \mathrm{~m}$ above sea level along the stream up into the small hanging valley with the lake ( $90 \mathrm{~m}$ above sea level) in the western part of Hvannhagi. At several places it cuts through the whole of the tuff-agglomerate zone, for example just east of Dysjarnar. West of Grønagjógv and particularly clearly east of Gásagjógv it sends apophyses up into the lower part of the middle basalt series.

On the north side of Trongisvágur intrusive basalts can be seen at intervals along the whole mountainside from the area west of Myllá to the area east of Tippisá.

West of Myllá, at a height of about $150 \mathrm{~m}$, there is a basalt mass, which is undoubtedly intrusive. It can be traced back as far as Myllá, where apophyses can be seen, both at the boundary between the agglomerate zone and the middle basalt series and farther down the stream about $4 \mathrm{~m}$ above an old mine adit. Both here and inside the old mine the intrusive basalt is in contact with the roof clay in the coal-bearing sequence. The intrusive basalt mass west of Myllá is exposed for a distance of about $180 \mathrm{~m}$; the greatest thickness, about $13 \mathrm{~m}$, is found along the central part. At a height of about $185 \mathrm{~m}$ on Myllá a dyke-like apophyses about $1 \mathrm{~m}$ wide goes up into the middle basalt series; it can also be seen going diagonally through the agglomerate in the gullies. On the western side of the gully its thickness is about $10 \mathrm{~m}$.

In $\varnothing \mathrm{kslin}$ intrusive basalt can be seen in the roof of an old mine adit.

In the area east of $\varnothing \mathrm{kslin}$ several smaller exposures with thicknesses of 10-15 m occur, which can probably be regarded as intrusive. Contacts or intersections have not been observed directly, but on the basis of their appearance and situation in the sequence they must be presumed to be intrusive.

At Tippisá and the area immediately east of Tippisá, at a height of between 130 and $150 \mathrm{~m}$ above sea level, exposures can be seen, which also must be presumed to stem from the irregular, intrusive basalt. 


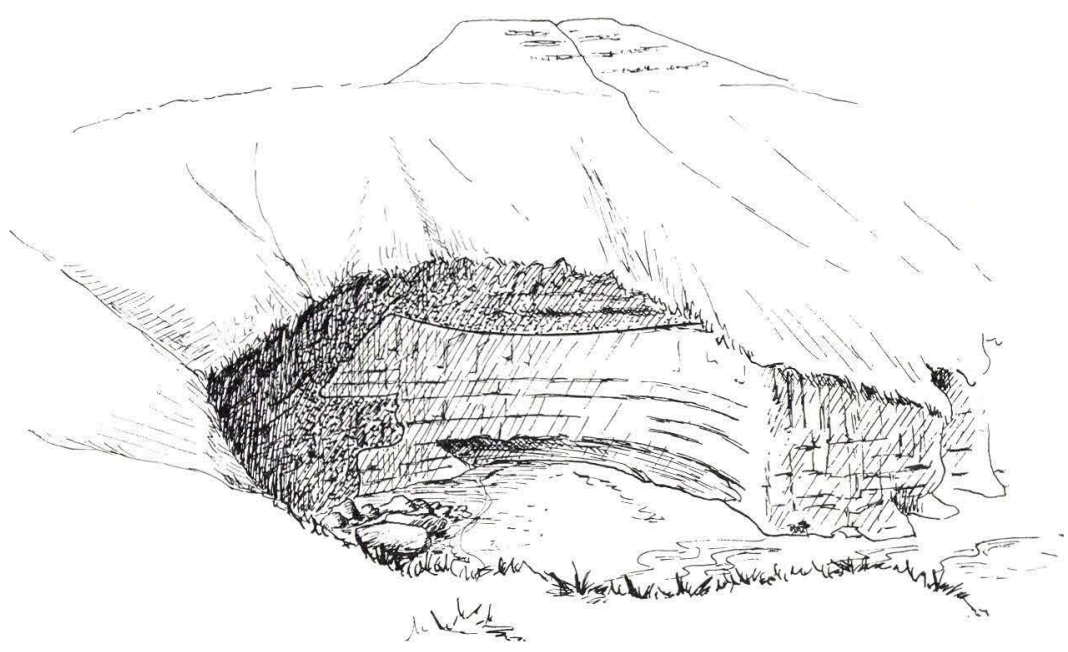

Fig. 44. Contact between intrusive basalt and the lowest part of the middle basalt series east of Akranessker.

On the south side of Trongisvágur there are intrusive basalts exposed in two old mine adits in Oyrnafjall and farther east.

\section{Tindhólmur and Vágar}

As on Suðuroy, the irregular intrusive bodies occur here also in connection with the tuff-agglomerate zone and its immediate surroundings. Forchhammer (1824) seems to have observed them on Tindhólmur, but those on Vágar do not seem to have been mentioned in the older literature.

The north side of Tindhólmur is poorly exposed; the south side, on the other hand, is almost vertical and the entire sequence: lower basalt series, coal-bearing sequence and the tuff-agglomerate zone with intrusive basalts and part of the middle basalt series can be seen exposed here in a vertical section (fig. 23).

On Vágar the irregularly intruded basalts can be observed from Akranes, between the villages of Bøur and Gásadalur, along the coast to the north-west to the area south of Barðið. Akranes and Akranessker consist entirely of intrusive basalts, and in the small bay east of Akranessker a vertical contact can be seen between the intrusive basalts and the lower part of the middle basalt series, which alternates here with tuff-agglomerates (fig. 44). The cliff at Akra- 
nesfossur consists predominantly of intrusive basalt with inclusions of tuff-agglomerate and clayey sediments stemming from the coalbearing sequence (fig. 21). Towards the north-west the intrusive basalts occupy part of the coastal area between Akranessker and Gásadalur (fig. 22), and they can also be seen in gullies with good exposures from Gásadalur to the area south of Barðið.

The intrusive basalt on Akranessker is cut by a dyke (Vá. 31); it can be seen again in the mountain wall inland (Vá. 30) and it continues up into the middle basalt series. The dyke has only a weak columnar structure, and its thermal contact is only weakly developed. The course of the dyke is rather irregular. With regard to both the conditions of intrusion and the rock type there is a remarkable resemblance with the dyke between Hamranes and Hvítanes on Suðuroy (Su. 2).

Samples from two main localities, Hvalbøur on Suðuroy and Akranes on Vágar, are very similar. The rocks are dark grey and medium-grained. They carry olivine visible to the naked eye. The Hvalbøur rock is doleritic in texture and has the composition of an alkalic olivine basalt (owing to zeolitic mesostasis?) The Akranes rock is intergranular and olivine tholeiitic. (Chemical analyses are given on p. 303 in the Memoir.)

Sills

Sills are formed by intrusion of magma in zones of weakness along bedding planes or surfaces of deposition in unfolded, originally horizontal sequences. Sills are relatively thin compared with their areal extent, and their course is generally speaking parallel (concordant) to the natural stratification in the surrounding rock. However, it is not uncommon to see a sill cutting one or more overlying beds or flows and thereafter continuing at another level along another surface with another orientation; in this way it becomes transgressive.

A common feature of all sills in the Faeroese basalt plateau is in fact a remarkable degree of transgression with a generally concordant form of intrusion in the central area of the sill but increasing transgression towards the periphery (Rasmussen 1951). 
Another common morphological feature in these sills is a prominent coarse prismatic columnar structure, which is particularly prominent in steep cliffs. The very regularly occurring columnar basalts in the lower basalt series have often been misidentified as sills.

In the older literature sills are first mentioned by von Born (1792, 1797). He gives a description with accompanying sketches of "støttebasalten" (pillar basalt) on Streymoy and Eysturoy. On Eysturoy he observed basalt of this type between Selatrad and north of Oyri and explains that these "basaltstøtter" (basalt pillars) form a horizontal band at the foot of the mountain below Halgafellstindur and Reyðafellstindur. On Streymoy von Born observed basalt of this type in Núgvan and Skælingur.

There are a number of accounts from the 19th century in which reference is made to sills, but this is more or less only in passing.

Landt (1800) mentions "st $\varnothing$ ttebasalter" on Streymoy and Eysturoy. Even if Landt's information is largely taken from von Born, he mentions as a new observation "støttebasalter" in Sátan. Allan (1813) mention "columnar greenstone" at Selatrað on Eysturoy and in Núgvan, Skælingur and Sátan on Streymoy. Trevelyan (1823) also mentions briefly, with accompanying sketches, "nonconforming greenstone" on Streymoy and Eysturoy. In Forchhammer $(1821,1824)$ there are descriptions of sills from Streymoy, Eysturoy and Svínoy. He assigns these together with the dykes to the youngest division of the Faeroese rocks, "den uregelmæssige trap" (the irregular trap). Geikie (1880) describes the well known columnar basalts at Froðba on Suðuroy as being intrusive, but he did not visit the previously mentioned sill localities in the northern islands himself; he refers here to Allan and Trevelyan. Lomas (1895) observed "intrusive sheets" on Fugloy, Svínoy and Streymoy. Like Geikie and others he considers that the columnar basalts at Froðba and on Mykines are also intrusive. Geikie (1896) discusses the large sill on Streymoy, and also thinks he observed sills on Kallsoy, Kunoy and other islands.

The Faeroese sills are not dealt with in more detail in more recent literature either; thus Bøggild (1922, 1928) mentions the two largest sills, the Streymoy sill and the Eysturoy sill only briefly. Simpson (1928) gives a brief petrographic description of the Streymoy sill, as do Walker and Davidson (1936), who also mention 
sills from Svínoy, Eysturoy, Vestmanna, Kunoy and Borðoy. Walker and Davidson do not consider that the columnar basalt at Froðba is intrusive, but interpret this as being "columnar lavas of Staffa type".

During the present work the following sills were mapped: one on Fugloy, one on Svínoy; in addition to the large sill on Eysturoy another smaller sill, and on Streymoy in addition to the large Streymoy sill three smaller sills or parts of sills. On the north-west side of Kallsoy a further small sill was observed high up in the inaccessible mountain wall (Rasmussen 1957).

\section{The Fugloy sill}

The Fugloy sill covers an area of about $1.25 \mathrm{~km}^{2}$; its thickness varies from $15-36 \mathrm{~m}$. It cuts through the island transgressively with a dip which is about due west, the average dip being about $9^{\circ}$ in the south-eastern part of the island. On the south side of the island it can be seen at sea level between Skoratangi and Nevið Óða. From here it rises up through the mountain wall in Grønaskor and can be seen as a prominent bench about $30 \mathrm{~m}$ thick above the village of Hattarvík. In the north-eastern part of the island, between Kellingará and Skarðsvík, only one exposure of the sill was observed, but in the steep cliff facing towards Skarđsvík it can be seen running down through the cliff, in the upper part approximately vertically and downwards with a decreasing dip towards the west, until where it reaches sea level it runs approximately horizontally and occupies the entire shore at Landfles.

In Grønaskor (about $250 \mathrm{~m}$ north of Krossur) the lower boundary of the sill lies at about $120 \mathrm{~m}$ above sea level, at Húsá about $80 \mathrm{~m}$ above sea level, between Húsá and Kellingará $104 \mathrm{~m}$ above sea level and at Kellingará $110 \mathrm{~m}$ above sea level. The upper boundary of the sill lies at $156 \mathrm{~m}$ above sea level in Grønaskor and at Húsá it is $95 \mathrm{~m}$ above sea level. At Húsá (80-95 m) the sill rock is a compact, blue, rather fine-grained basalt with a characteristic vertical jointing. The rock overlying it here is a compact, blue basalt with scattered zeolites; the underlying flow also consists of a compact, blue basalt, which is vesicular and scoriaceous at the top. 


\section{The Svinoy sill}

The Svínoy sill, like the Fugloy sill, occupies a rather limited area - about $1 \mathrm{~km}^{2}$. Just like the Fugloy sill it is transgressive and cuts through the northernmost part of the islands with NNW dip in the easternmost part and $\mathrm{N}$ and NE dip in the westernmost part. In the steep cliff at Kallanes the sill reaches sea level. From here it rises towards the south-south-east; about $300 \mathrm{~m}$ south of Kallanes its lower boundary lies at about $75 \mathrm{~m}$ above sea level and about $700 \mathrm{~m}$ south of Kallanes at about $92 \mathrm{~m}$; it does not continue any farther south, but follows an E-W trending line in the terrain up to the small hillock "Mađur". After this it suddenly rises towards the south-west up to Keldufjall to about $460 \mathrm{~m}$, after which it can be seen descending in the northern gjógv in Keldufjall with a north-north-east direction through Norðskor towards Selnes.

The surface of the sill is only exposed in the north-eastern part of the island. The sill reaches the coastal cliff at the stream west of Kallanes and from here its upper boundary can be followed as a sinuous line towards the south, west and thereafter towards the south-west up to Keldufjall. From a height of about $300 \mathrm{~m}$ up to the top of Keldufjall both the lower and the upper contacts of the sill can be seen locally; at a height of $385 \mathrm{~m}$ and close to the top the distance in the field between the two contacts was measured as about $40 \mathrm{~m}$. The Svínoy sill is particularly prominent in the vertical cliff at Selnes, where it can be seen as a black band that cuts through the basalt flows and rises towards the south-south-west up to Norðskor. Its lower boundary here lies at about $60 \mathrm{~m}$ above sea level and its thickness is about $30 \mathrm{~m}$, which corresponds to the thickness on the east side of the island.

The rock type in the Svínoy sill seems to be identical with the rock type in the Fugloy sill and just as in the Fugloy sill we find towards the lower contact zone a pronounced fracturing in the rock, with formation of small, sharp-edged fragments.

All things considered it seem reasonable to presume that both sills are part of the same intrusion, the Fugloy sill forming the north-eastern transgressive flank and the Svínoy sill at Keldufjall forming part of the south-western transgressive flank of one and the same sill. 
NV

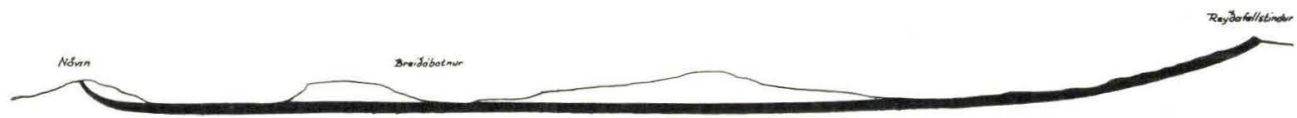

Fig. 45. Longitudinal section through the Eysturoy sill.

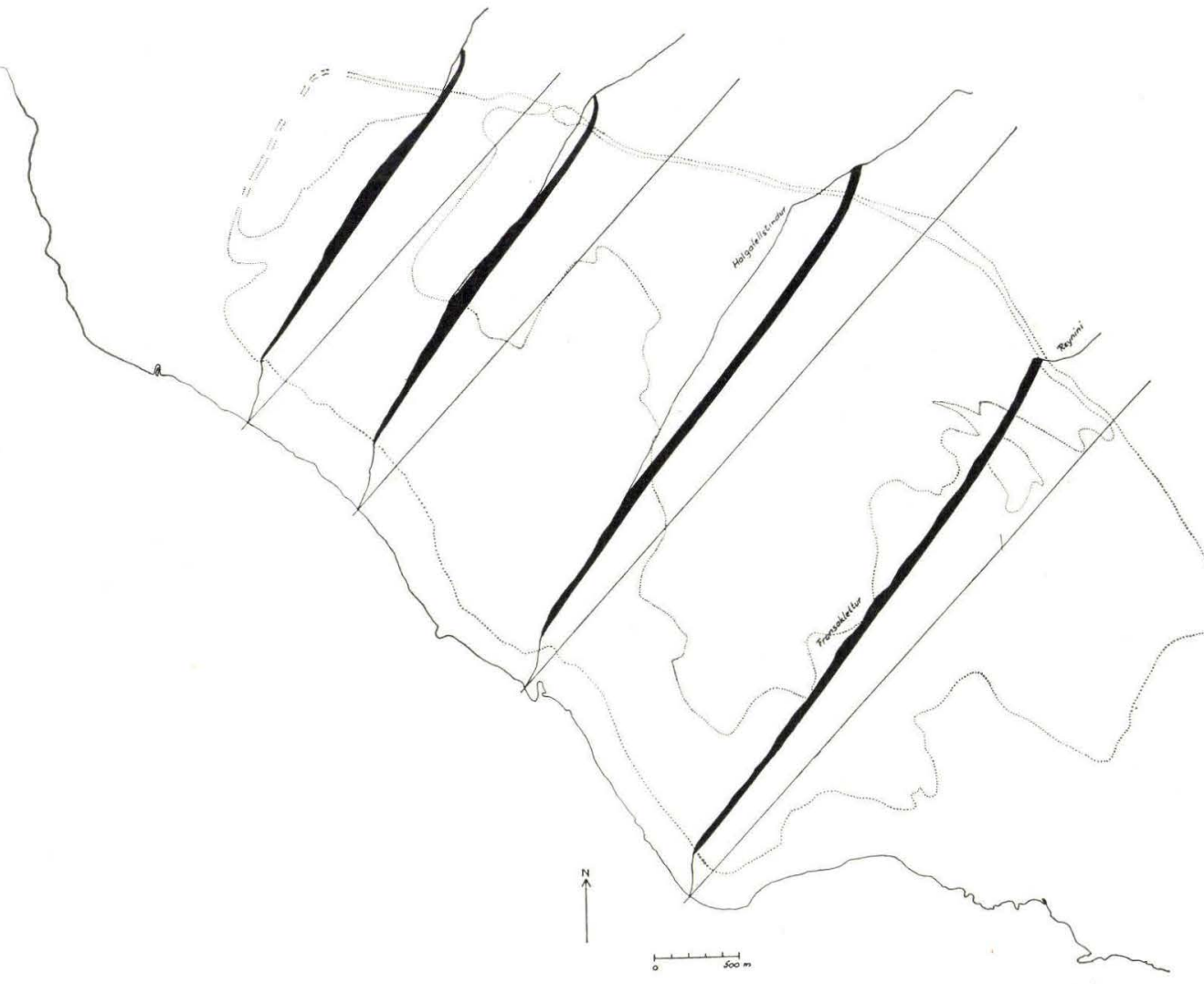

Fig. 46. Cross sections through the Eysturoy sill. 


\section{The large Eusturoy sill}

The large Eysturoy sill lies in the area between Reyðafellstindur, Veoranes, the village of Oyri, and Nøvin. It is $6.5 \mathrm{~km}$ long in the SE-NW direction, has a width of from just under $2 \mathrm{~km}$ to $3.5 \mathrm{~km}$ and occupies an area of about $16 \mathrm{~km}^{2}$. Along the coast section Veoranes-Oyri its western boundary can be seen in the form of an unbroken bench with columnar structure, which is situated at its lowest around Breiðá and climbs slightly towards the south-east and the north-west. In this section the lower boundary of the sill is to be found at $152 \mathrm{~m}$ above sea level in Veđranes, at $80 \mathrm{~m}$ west of Breiðá, at $165 \mathrm{~m}$ midway between Breiðá and the fence on the south of the field at Oyri and at $175 \mathrm{~m}$ above sea level in a stream at the fence on the south of the field at Oyri. The area at Breiðá must therefore be regarded as being the central area of the sill; from here it rises everywhere to the north-west, north, north-east, east and south-east. (See figs. 45, 46.)

On the south-eastern side of the sill it is possible to see directly the transgressive rise towards the east. The lower border of the sill, which is at a height of $152 \mathrm{~m}$ above sea level at Veðranes, is at about $170 \mathrm{~m}$ in the river east of Argisgjógv, at about $225 \mathrm{~m}$ east of Blásendi, at about $305 \mathrm{~m}$ at Sandá and at $332 \mathrm{~m}$ above sea level at Rókin. From here it climbs abruptly up towards Reyðafellstindur, following a SW-NE trending vertical line, so that the whole of the steep north-western side of the mountain and the top of the mountain, which stands up as a peak above the basalt of the plateau and reaches a height of $766 \mathrm{~m}$, are composed of the sill, while the south-western side of the mountain consists of plateau basalts.

We find the same abrupt, transgressive ascent again towards the north in the area north-west of Oyrargjógv and along the whole of the eastern boundary of the sill, so that the peripheral part of the sill in the north and east locally forms an approximately vertical intrusion resembling a dyke in the field, with considerably less thickness than that found in the west-central part of the sill.

The entire floor of the large cirque that runs north-eastwards from the village of Oyri is composed of the exposed surface of the sill. It can be seen on both sides of Oyrargjógv and it extends up towards Oyrarskaro, being cut by the gjógv. The sill climbs steadily up towards the north and north-east to about $430 \mathrm{~m}$, after 


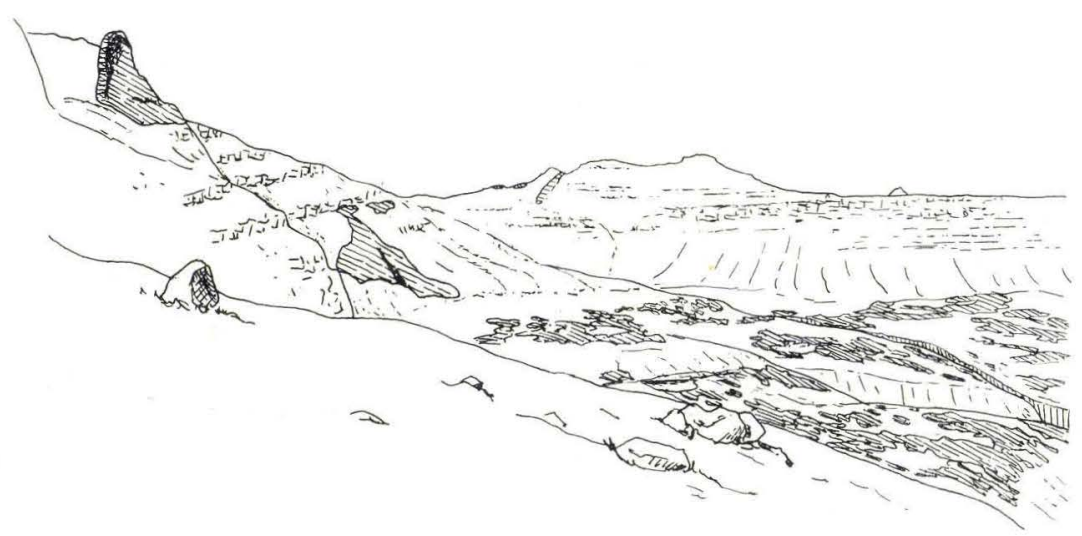

Fig. 47. The Eysturoy sill at Oyrargiogv, viewed from the south. The exposed wall can be seen in the upper part of the figure.

which it climbs more steeply up towards Oyrarskarð and towards the north up towards the mountain Nøvin. A few hundred metres east of trigonometrical station 626 on Nøvin part of the exposed northern wall of the sill can be seen as an almost vertical wall up against the plateau basalt of the mountain; it is thus possible here to observe almost the whole of the transition from the lower flatlying part of the sill to the almost vertical peripheral part in the north. Its thickness here is about $4 \mathrm{~m}$ (fig. 47).

From here it can be followed in places to the west side of Nøvin, and from there in a south-south-east direction, where it transects the basalt flows at a height of about $600 \mathrm{~m}$, down towards the mouth of Oyrargjógv. In the whole of this section it can be seen in the field as a dyke-like intrusion varying from about $4 \mathrm{~m}$ to about $8 \mathrm{~m}$ in width. In the area between Oyri and Norðskáli small apophyses from the sill were observed at several places at a lower level.

The eastern boundary of the sill can be followed from Oyrarskaro in the north to Reyðafellstindur in the south. At Lágarhálsur, above Skálabotnur, the sill forms a high, vertical cliff. From this place it runs in a south-south-east direction up to the top of Reyðafellstindur. North-north-west of Lágarhálsur the sill transects the basalt flows west of Halgafellstindur; the thickness is about $55 \mathrm{~m}$. The lower boundary lies at a height of $510 \mathrm{~m}$ and the upper boundary at a height of $565 \mathrm{~m}$. From here it rises towards the west-north-west with reducing thickness; between Halgafellstindur 
and Kelduklettur it is thus only about $10 \mathrm{~m}$ thick. Along Kelduklettur and Sandfelli the sill is once more approximately vertical. It has jointing transverse to the chilled contacts on both sides. In this interval it can only be observed locally since it is covered by superficial deposits. At Oyrarskarð it is broken and forms small isolated occurrences in the terrain.

While about half of the sill is covered by the mountain chain Nøvin, Sandfelli, Kelduklettur and Halgafellstindur and the southwest slopes of these mountains, the surface of the sill is exposed in the whole of the area between Reyðalsfellstindur, Lágarhálsur and Veðranes, and in the area Veðranes, Oyrargjógv, Breiðábotnur. The upper boundary of the sill can be seen south-west of Sandfelli at $415 \mathrm{~m}$ above sea level, in the stream in Breiðábotnur due south of Sandfelli at $420 \mathrm{~m}$ above sea level, at the stream in the continuation of Oyrargjógv in Breiðábotnur at $430 \mathrm{~m}$ above sea level and in Sølvá at $225 \mathrm{~m}$ above sea level. In the southern area the thickness is about $50 \mathrm{~m}$; the surface is ice-scoured and poor in vegetation; in the southern area it is irregular and undulating. The original surface of the sill can be seen at several places, e.g. at Fransahús and Blásendi, where there are remains of the chilled marginal material on the ends of the polygonal columns.

In Knubbagil a dyke with a width of about $3 \mathrm{~m}$ can be seen (Ey. 82); it is visible again at Ryssugil (Ey. 83), but not in the sill area between Fransahús annd Ryssugil or in the sill area farther towards the south-east; it is thus interrupted at (cut by) the sill. The dyke follows a NW-SE trending lamellar zone, which was originally formed before the dyke was intruded, but was also active afterwards and resulted in a fracture system with the same direction in the sill.

North-west of Oyrargjógv (at Oyri) a dyke (Ey. 202) can be seen running up along the north-west wall of the sill. At a height of about $250 \mathrm{~m}$ it reaches and forms a contact with the sill. It can clearly be seen from the contact relations that the sill was intruded later and thus is younger than the dyke.

\section{The large Streymoy sill}

The large Streymoy sill is situated on the west side of Streymoy out towards Vágafjørður and Vestmannasund. Just like the large Eysturoy sill it belongs to the earliest-observed and earliest-described 


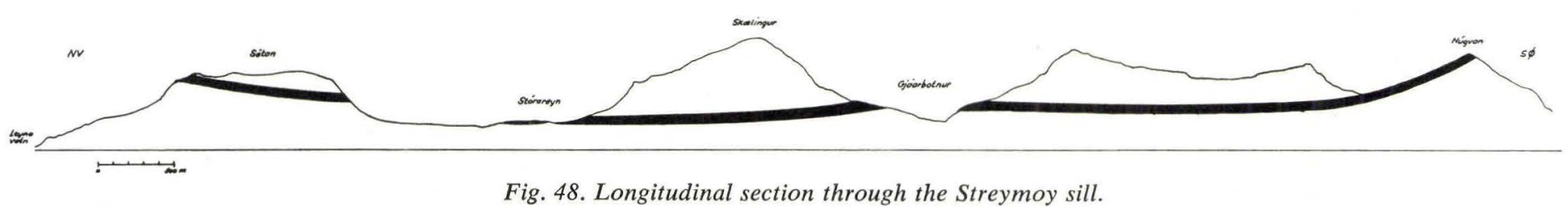

Fig. 48. Longitudinal section through the Streymoy sill. 


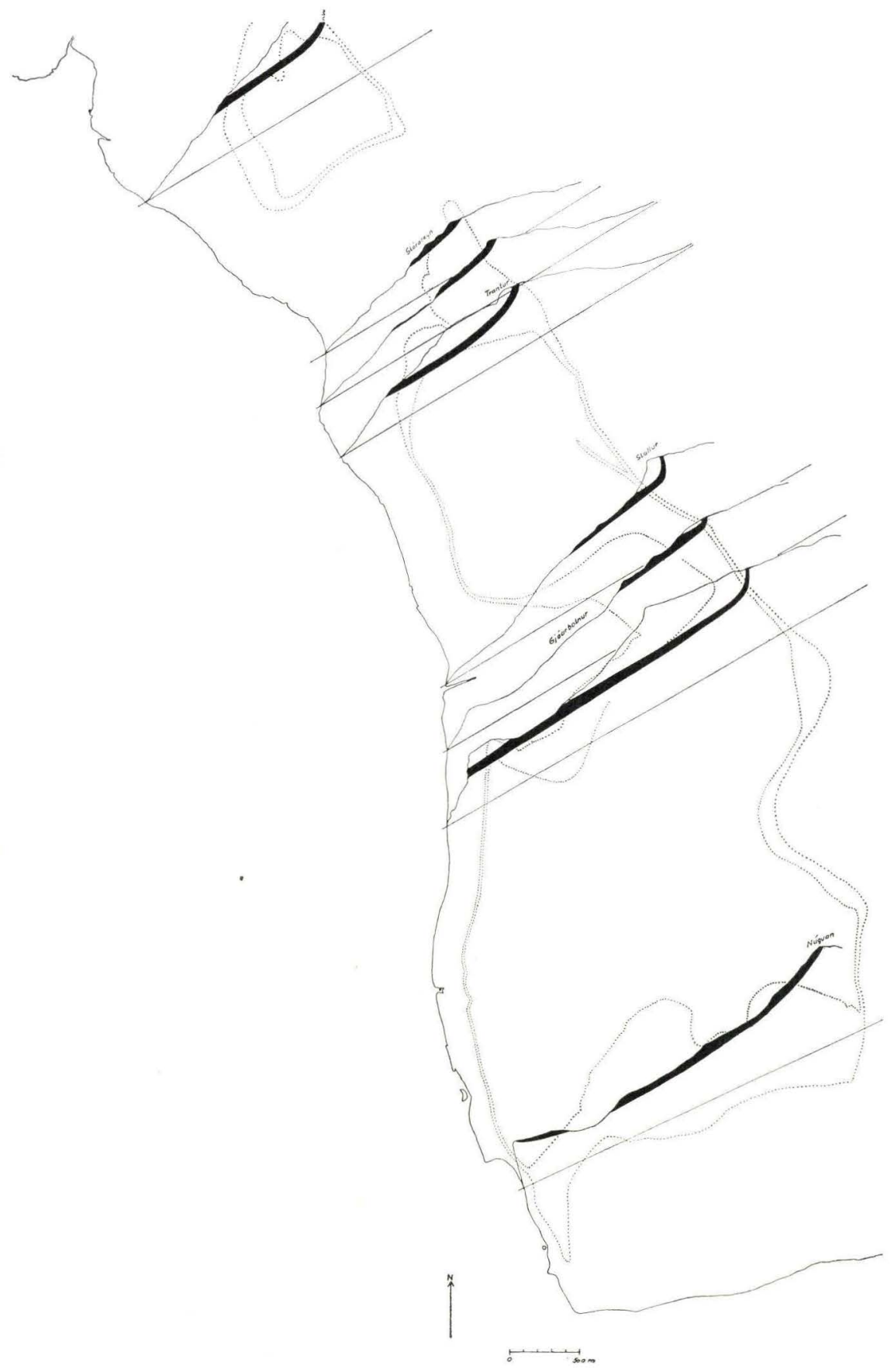

Fig. 49. Cross sections through the Streymoy sill. 
Faeroese sills. It has a NNW-SSE trend and extends from the mountain Sátan in the north to Núgvan in the south; the length of the outcrop is about $9 \mathrm{~km}$ and the width of the outcrop varies from $1-2 \mathrm{~km}$ in the north to $2-3 \mathrm{~km}$ in the south. It occupies an area of about $13 \mathrm{~km}^{2}$. At Skælingsskarð, between Sátan and Stórareyn, the erosion has been so deep that is has divided the sill into a smaller northern part on Sátan and a larger southern part in the area Stórareyn-Núgvan. (See figs. 48,49 .)

The Streymoy sill and the Eysturoy sill show to a marked degree common morphological features. The Streymoy sill, like the Eysturoy sill, is highest in the north and in the south and like the Eysturoy sill it is increasingly transgressive towards the east, where it sometimes dips so steeply to the west that the chilled contacts instead of forming a floor and a roof to the sill form east and west margins.

The western boundary of the sill follows in general the normally deposited basalt sequence from Kollfjarðargjógv in the north to Reipaskor in the south, except in the area at Gjáarbotnur, where a distinct upwards arching can be seen. From Kollfjarðargjógv and from Reipaskor its course is on the other hand strongly transgressive towards the north and towards the south respectively.

The position of the lower boundary of the sill is as follows:

Along the west side. Kollfjarðargjógv 302 m, south-east corner of Sátan $227 \mathrm{~m}$, west side of Skælingur $193 \mathrm{~m}$, south side of Gjáarbotnur $242 \mathrm{~m}$, Reipaskor $170 \mathrm{~m}$ (height taken from map) and Dalsnípa $315 \mathrm{~m}$.

Along the medial line. Northern Sátan $480 \mathrm{~m}$, southern Sátan 337 m, Kálvadalsá 198 m, north side of Gjáarbotnur 302 m, south side of Gjáarbotnur $288 \mathrm{~m}$ and Áarstíggjafossur $218 \mathrm{~m}$.

Along the east side. North of Klettsgjógv $514 \mathrm{~m}$, south of Skælingsskarð $310 \mathrm{~m}$, east side of Stórareyn $370 \mathrm{~m}$, west of Trantur 375 m, Hundsarabotnur $400 \mathrm{~m}$, Stallur $580 \mathrm{~m}$, Bláhamar $430 \mathrm{~m}$, Mjørkadalur $390 \mathrm{~m}$, south side of Mjørkadalur $445 \mathrm{~m}$, north of Núgvan $562 \mathrm{~m}$ and Núgvan $630 \mathrm{~m}$.

The increasing transgression towards north, south and east is thus marked, except for local variations.

On Sátan the sill is exposed from Kollfjarđargjógv northwards as far as the area west of Navagjógv. In addition, the whole of the northernmost part of the mountain, Navirnar, is composed of the sill. The original, finely jointed surface of the sill can be seen in 
many places. It often shows the form of the lower surface of the overlying flow and also contains fragments of it. From Kollfjaroargjógv southwards the sill is partly concealed by superficial deposits. Towards the south it can be seen in vertical section in the steep mountain wall, climbing regularly towards the east to Klettsgjógv, after which it suddenly rises east of Klettsgjógv and towards the east forms a steep columnar-jointed bench with a south-west dip of about $15^{\circ}$. West of Klettsgjógv an apophysis of the sill goes downwards, bends towards the west and transects the underlying basalt flows. It is about $2 \mathrm{~m}$ wide and has a slightly sinuous, irregular course. The thickness of the sill, which is $30-40$ $\mathrm{m}$ on the west side of Sátan (at Kollfjarðargjógv), is about $20 \mathrm{~m}$ at Navagjógv in the north, about $20 \mathrm{~m}$ ind the middle of the cliff on the south side and is also about $20 \mathrm{~m}$ on the east side (north of Klettsgjógv).

South of Skælingsskarð large parts of the sill are exposed at Stórareyn, in Gjáarbotnur and on the north-west side of the mountain Núgvan. Along the west side of Skælingur and the mountains south of Gjáarbotnur the course of the sill can, on the other hand, only be observed in an inaccessible, steep mountain wall.

At Stórareyn the surface of the sill is hummocky and forms bare rocky mounds, with small patches of vegetation or small lakes in the depressions between the individual mounds or hillocks. The surface is distinctly ice-scoured and shows that the ice moved towards the west. Up towards Trantur the terrain is covered by vegetation and gravel, and the upper contact of the sill cannot be observed directly.

The whole of the top part of Gjáarbotnur and its south side consist, just like Stórareyn, of the exposed sill. On the north side of Gjáarbotnur the lower boundary of the sill lies at $302 \mathrm{~m}$ and the upper boundary at $348 \mathrm{~m}$ above sea level. On the south side the lower boundary of the sill is situated at $288 \mathrm{~m}$ and the upper boundary at $340 \mathrm{~m}$ above sea level. The thickness here must therefore be about $50 \mathrm{~m}$. Just as in the area at Stórareyn the surface of the sill is hummocky and bare, but there is a little vegetation in the depressions and between the ends of the columns. On the original surface of the sill there are frequent remains of the contact and remains of the overlying flows. Ice-scouring can be seen locally. The sill can be followed through Skælingsskor southwards to Dosshellu- 
gjógv. It runs here in the middle of the cliff and appears with sharply bounded vertical columns.

Along the line Reipaskor (about $170 \mathrm{~m}$ ) in the west to the stream in the middle of Mjørkadalur (about $360 \mathrm{~m}$ ) in the east the sill is situated at its lowest. From here it climbs with strong transgression towards the south-east, its lower boundary being at a height of $315 \mathrm{~m}$ at Dalsnípa, at $218 \mathrm{~m}$ at Áarstíggjafossur and at $630 \mathrm{~m}$ on the south-east corner of Núgvan. The bare surface of the sill covers the whole of the steep north-west side of Núgvan. In the remainder of the valley Omanfyri Stígar the terrain is covered by soil and vegetation; the upper boundary of the sill can therefore only be recognized locally down along the watercourse leading to the small lakes in the valley. No observation was possible in the valley.

On the northern point of Stórareyn the sill has a westwards dip of about $30^{\circ}$. From here its eastern boundary can be followed towards the south-east to Bláhamar and from there south as far as Núgvan. The sill shows the least thickness at Hundsarabotnur, where for a short distance it is only 5-7 m thick. From Stígaskarð a large apophysis goes from the top of the sill in a northwest direction and a few smaller, sinuous apophyses go down towards Hundsarabotnur. From Stígaskarð the sill rises abruptly up to Stallur and cuts the mountain; its course at Stallur is almost vertical, the sill having a south-west dip of about $75^{\circ}$. The lower boundary here is situated at a height of $580 \mathrm{~m}$ and the thickness amounts to about $15 \mathrm{~m}$. From Stallur it continues with about the same thickness, 15-20 m, to Bláhamar. The south-west dip here is so great that the sill when seen in the field resembles a dyke with finely-jointed contact zones on each side. At Bláhamar the thickness increases at the same time as the westwards dip decreases again. Most of the upper half of the vertical cliff Bláhamar consists of high, almost vertical columns. From Mjørkadalur the sill then climbs abruptly, as mentioned previously, up to Núgvan. (See fig. 50.)

A dyke (Str. 217) can be seen on Sátan. Its trend is about NW-SE and it can be followed across the mountain towards Navagjógv. In the southern, vertical wall of the sill west of Klettsgjógv the dyke can be seen to be cut by the sill and is thus older than the sill. The dyke in Navagjógv (Str. 209) can also be seen to be cut by the sill. The same applies to the dyke in Ravnagjógv (Str. 216). 


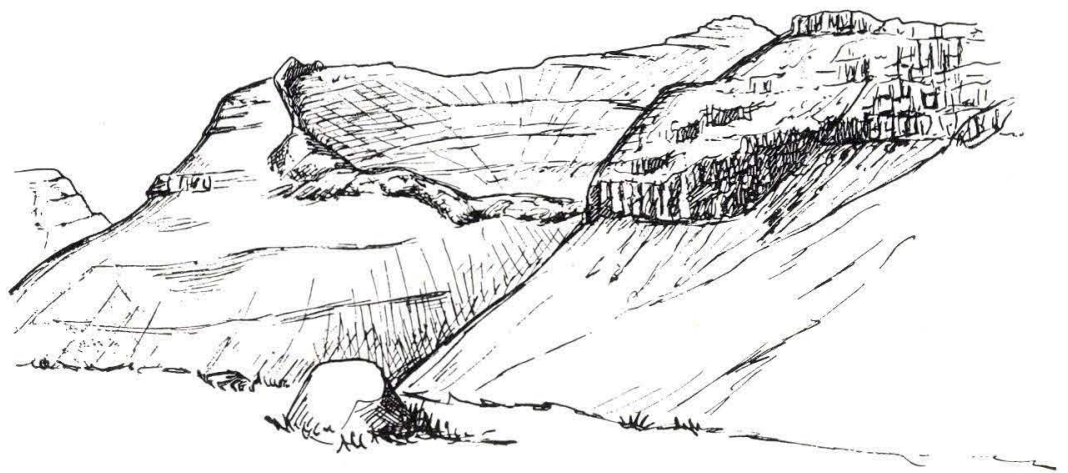

Fig. 50. The Streymoy sill, Bláhamar-Núgvan.

This dyke can be followed up towards the sill, its trend being about NW-SE, but it can however not be seen to cut the sill, which is however strongly jointed in the direction of the dyke. Above the sill up towards Trantur the dyke can be seen again (Str. 215). This dyke is also older than the sill. In Gjáarbotnur a dyke runs with an approximately east-north-east direction up towards the sill; it shows a thermal contact against the wall rock below the sill, but it passes gradually without any transition into the sill itself. It cannot be seen above the sill. It must therefore be a feeder to it.

In Kollfjarðargjógv a dyke can also be seen running up towards the sill, with an approximately eastwards direction. It cannot be seen in the area of the sill or farther up. However, a more precise relation to the sill cannot be determined with certainty since the area of intersection is covered by scree and vegetation.

\section{Other sills}

The sill in Hægstafjall, west of Vestmanna, only has a limited areal extent and thickness. It is only about $500 \mathrm{~m}$ long and about $4 \mathrm{~m}$ thick. Towards the north its lower boundary is situated at a height of $280 \mathrm{~m}$ and its upper boundary at $284 \mathrm{~m}$; in the south-west corner the heights are $254 \mathrm{~m}$ and $258 \mathrm{~m}$ respectively and in the south-east corner $272 \mathrm{~m}$ and $276 \mathrm{~m}$ above sea level respectively.

Between Kvívik and Vestmanna remnants of intrusive material can be seen at scattered localities; these remnants on closer inspection have been proved to stem from a sill-like intrusion with a rather irregular course. The area containing the intrusive remnants 
extends over about $11 \mathrm{~km}^{2}$. The sill is most prominent along the east side of Gásafelli and at Bornsvarði. The lower boundary south of Gásafelli lies at a height of $314 \mathrm{~m}$ and north of Gásafelli at a height of $400 \mathrm{~m}$. Between Bornsvarði, Eigilsfjall and Gásafelli and down in the valley between Eigilsfjall and Gásafelli scattered intrusion remnants can be seen; because of the deep erosion these are now not connected with each other. This sill can be followed from Bornsvarđi westwards down through Hvannadalur, southwards along Øklin into Gassádalur to Høgareyn and thereafter eastwards to Kvívík. At Bornsvarði the sill lies at a height of about $400 \mathrm{~m}$; it descends towards the west. North of $\varnothing \mathrm{kslin}$ (at the path) it can be seen at a height of $250 \mathrm{~m}$. The thickness in Hvannadalur is only 2-4 m. In Gassádalur, southwards along Høgareyn and eastwards towards Kvívik it can only be seen in places. In Gassá it is visible at a height of about $180 \mathrm{~m}$, on the west side of Høgareyn at a height of about $220 \mathrm{~m}$ and at Breiðá at a height of about $190 \mathrm{~m}$. The thickness along this stretch is only 1-2 m. In Víkará, which runs through the village of Kvívík, the lower contact of the sill can be seen at $139 \mathrm{~m}$ above sea level and the upper contact at $146 \mathrm{~m}$ above sea level.

A small sill runs from Hórisg $\varnothing \mathrm{ta}$, on the south side of Kollafjørður, eastwards to the area east of Bláfossur; it is about $800 \mathrm{~m}$ long and 10-20 m thick. Apophyses can be seen both west and east of, and above, the main intrusion.

At Morskranes a sill can be observed extending from Kveistrastórá north of Morskranes (about $40 \mathrm{~m}$ above sea level) southwards as far as Melheyggjur and then towards the east and north, where it disappears. At Melheyggjur the lower boundary lies at a height of about $170 \mathrm{~m}$ and the upper boundary at a height of 184 $\mathrm{m}$. The sill can be followed for a distance of about $4.5 \mathrm{~km}$.

The two large sills on Streymoy and Eysturoy consist of quartz tholeiitic basalt. The sill on Fugloy and Svínoy consists of olivine tholeiitic basalt. (Chemical analyses are given on p. 325 in the Memoir.)

\section{Intrusion mechanism}

As mentioned previously all the larger Faeroese sills, the Streymoy sill, the Eysturoy sill and the Fugloy-Svínoy sill, have this in 
common that they are transgressive and form saucer-shaped bodies whose western half is missing. Both the Streymoy sill and the Eysturoy sill show increasing transgression towards the north, south and east. However, since the southern part of the Streymoy sill also shows increasing transgression towards the south-west from the line between Reipaskor (170 m above sea level) and Áarstíggjafossur ( $218 \mathrm{~m}$ above sea level) to Dalsnípa (315 $\mathrm{m}$ above sea level), it is likely that there was originally a western half to the saucer but that this was removed later during the formation of the fjords.

The intersections between sills and dykes mentioned previously (see pp. 121, 126, 127) show that in all cases seen the sills described are younger that the dykes. At some localities dykes were observed to stop at the lower boundary of a sill and could not be seen above the sill. At one of these localities, in Gjáarbotnur (Str. 224), the contact zone itself was exposed and complete passage from dyke to sill was found; it must therefore be presumed that these were intruded simultaneously and that the dyke has been a feeder for the sill.

It was also mentioned during the discussion of the mode of intrusion of the Hamranes-Hvítanes dyke (Su. 2) and the Akranes dyke (Vá. 30, 31) in the section on the irregular intrusive bodies that the contact relations were such that it must be regarded as likely that the intrusion of the basalts in the coast and the intrusion of the dyke took place simultaneously. (See pp. 110, 114.)

On this basis we must conclude that dykes, sills and irregular intrusions in general belong to the same phase of eruption.

The zones of weakness that have been permeated by intrusive material are of various types. The dykes were emplaced in vertical or steeply dipping lamellar zones; the irregular intrusive bodies were emplaced in the tuff-agglomerate zone and the coal-bearing sequence, and the sills were emplaced in the boundary area between the middle and upper basalt series. Smaller sills at a somewhat lower level (e.g. the Vestmanna sill and the Morskranes sill) are probably apophyses from the Streymoy sill and the Eysturoy sill respectively.

The history of intrusion must therefore be presumed to have been as follows. The dykes were intruded first in the previously existing lamellar zones; they are younger than the formation of the plateau basalts since they transect the whole sequence. Simultaneously with the dyke intrusion magma penetrated into the littleresistant and porous tuff-agglomerate zone. After all lamellar zones 

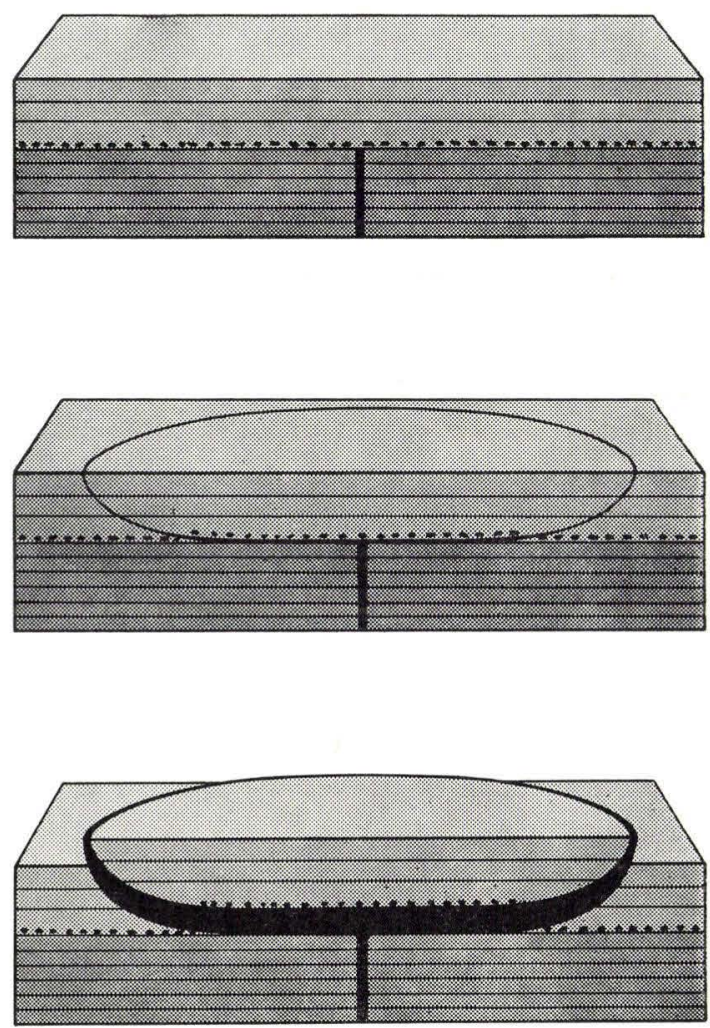

Fig. 51. Schematic drawing of a subsurface block showing the mechanism of sill intrusion.

were injected and the dykes had consolidated in the top part of the sequence the magma continued to push its way upwards and penetrated into the boundary area between the middle and upper basalt series. An overlying basalt mass thus became lifted up and the magma penetrated into the resulting clefts, which pointed in towards the feeder channel, with the formation of the transgressive peripheral parts of the sill (fig. 51). 


\section{Lamellar zones, gjógvs and faults}

\section{Lamellar zones}

The symbol used on the geological map for lineaments comprises some distinct fracture lines - joints and lamellar zones. Some of these were drawn during mapping and reconnaissance work and some from aerial photos.

The terms sprakker or revner and lamelzoner (Noe-Nygaard 1940) (joints or fissures and lamellar zones) correspond in general to the terms minor joints and master joints used by Peacock (1928).

Lamellar zones are formed by repeated adjustments to pressure along the same plane in the basalt plateau because of instability in the substratum immediately below the basalts.

Once a joint or fissure has been formed by pressure equalization there will be a tendency for later pressure equalization to occur at the same place along the same plane. A succession of pressure or tension equalizations will thus give rise to a zone of weakness consisting of a whole system of parallel joints or fissures - a lamellar zone. Erosion of lamellar zones often gives rise to deep gullies (Faeroese: gjógv pl. gjáir). In the bottom of one of these gjógvs it is often possible to see an exposure of a lamellar zone that has been washed clean by water action; it can be seen to consist of a frequently large number of parallel basalt lamellae with intervening crushed material and mineralized veins. Not infrequently thin bands of fuller's earth (montmorillonite) can be seen between the basalt lamellae. In recent years we have also had a chance to study lamellar zones at various depths, to which access has been obtained as a result of blasting in connection with work on tunnels for water and roads. If the roof above the tunnel is thin the lamellar zones, particularly when they carry water, are often a considerable nuisance during blasting work, since they can be very loose. 


\section{Gjógvs}

The term gjogv is used in everyday Faeroese to describe more or less deep, narrow, and often long gullies with steep, sometimes vertical walls. Gullies of this type are a very characteristic feature of the Faeroese landscape; their course is usually roughly straight or slightly curved, and they often occur in lines since they follow fracture lines (lamellar zones), which can be traced as lineaments on the ground from gully to gully. As an example of a line of gjógvs mention can be made of the line stretching from Gøtugjógv on the east side of Eysturoy to Saksun on the north-west side of Streymoy. It comprises somewhat more than 10 larger and smaller gjógvs ranging in length from about $2 \mathrm{~km}$ (Gøtugjógv) to less than $100 \mathrm{~m}$ (east of Norðskáli). This is a distance of about $25 \mathrm{~km}$, of which 5-6 km altogether has been eroded to form gjógvs. *

We can obtain an impression of the number of gjógvs by counting the symbols for gjógv on the map sheets of the Faeroe Islands at scale 1:20,000; when all the larger and smaller gjógvs are counted there are about 800 all together.

The gjógvs already attracted attention at an early stage and are thus mentioned and their origin discussed by von Born (1792, 1793), Landt (1800) and Mackenzie (1813); all these authors show that there are often columnar basalts in the gjógvs, and Mackenzie also considers that the gjógvs have originated by the breaking-up of the horizontally lying basalt columns, which thereafter are washed away by running water. This is also the opinion of Rudolphi (1913). Peacock (1928) indicates a tectonic origin for the gjógvs (fig. 52).

In recent years the origin of the gjógvs has been discussed by Noe-Nygaard (1940) and Rasmussen (1955).

As mentioned on p. 105 it can often be seen that a dyke is horizontally dislocated where it is crossed by another dyke that is lamellated along its length or by a non-intruded lamellar zone. When we consider the rose diagrams for dykes, lamellar zones and gjógvs we find a quite remarkable agreement between the directions of the lamellar zones and the gjógvs, while there is no such correspondance between the dykes and the lamellar zones. (See p. 108.)

* The term gjógv is also used in Faeroese with another meaning, viz. caves eroded by the sea in steep cliffs. It is also sometimes used to describe a small inlet with a more or less steep bounding cliff. 


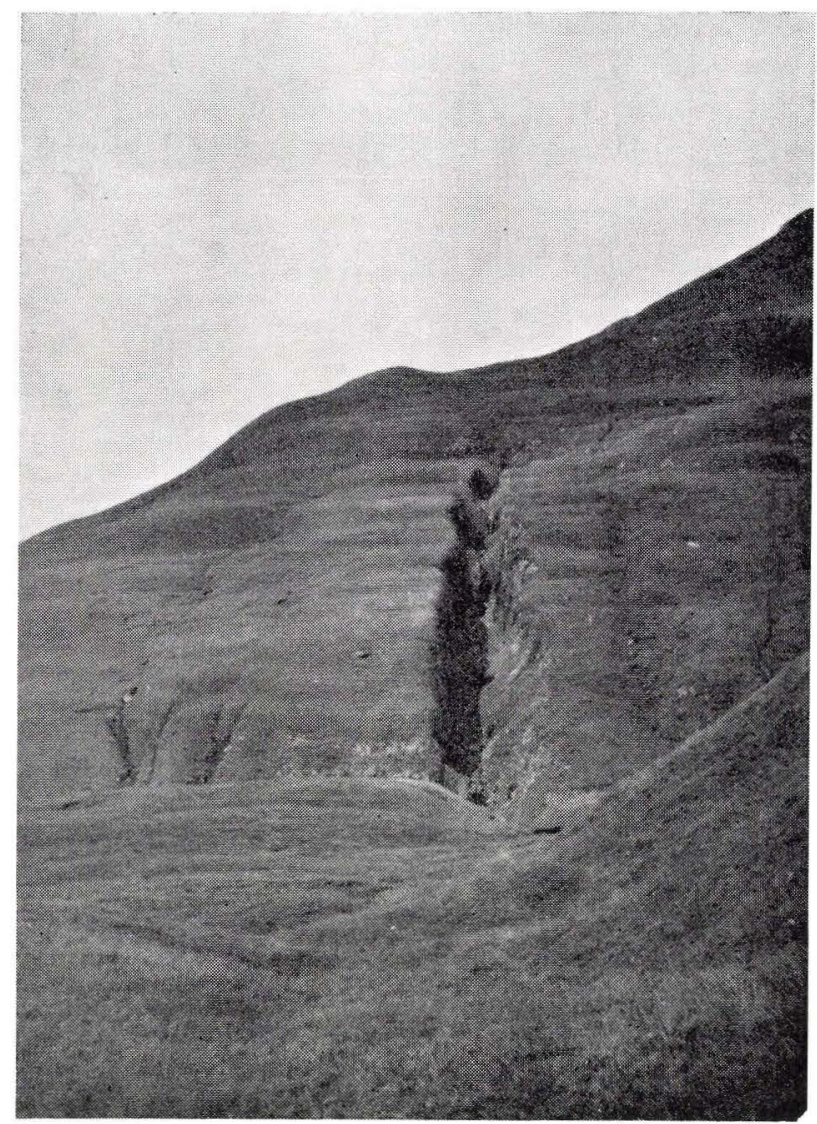

Fig. 52. Ravnagjógv, Streymoy.

It must therefore be presumed that the dykes were intruded in a joint or lamellar zone system, whose origin in time was just after the formation of the plateau, while the gjógvs are mainly connected with a lamellar zone system that is younger than the dyke intrusion.

\section{Faults}

On the geological map a number of faults are shown which we had a particular opportunity of seeing out towards the open coasts and in the fjords, because they are best exposed here. A small square on the map shows which side is downthrown with respect to the other and the Arabic numeral in the square shows the amount of down- 
throw in metres. The amount of vertical movement that can be measured on these faults ranges from less than a metre to several metres; the greatest vertical displacement on a fault that we have observed only exceptionally exceeds $20 \mathrm{~m}$. In zones that contain several faults however, for example on south-east Suðuroy, a clear tendency can be seen for all of them to show downthrow on the same side so that the total amount of movement on all the faults becomes quite considerable; other zones with many small faults show a more irregular pattern, for example an area south of Tjørnuvík on Streymoy (Noe-Nygaard 1945).

A picture that corresponds exactly to what can be seen in a vertical section can be found in horizontal exposures. Movements can be seen in these representing a few metres relative displacement between the two sides; this is particularly clear in cases where a dyke is cut by a fault. The largest horizontal displacement we have seen can be found on the geological map at Tjørnuvík, where two parts of the same dyke south-east and north-west of the fjord respectively are displaced almost $100 \mathrm{~m}$ in relation to each other (see p. 105).

We have also noticed that a rotation can occur on a vertical fault plane, so that a block that has moved is raised at one end and lowered at the other end relative to the neighbouring block. A particularly well developed fault zone is bounded by Dalagjógv and Djúpadalsgjógv in western Streymoy, where a whole system of smaller faults follows the same pattern shown by the two large faults in the main gjógvs, viz. an uplift towards the west of a triangular, fault-bounded block (see pp. 105, 106).

The faults that we have drawn on the map form only a small part of those that occur; the faults were seen during the mapping, often under very unfavourable conditions for observation - from a boat. Unfortunately it was not possible to find the time to pursue the fault problem for its own sake. Any future tectonic analysis of one or more of the particularly suitable areas will undoubtedly be able to throw light on the mechanism of movement within a rigid basalt plateau undergoing deformation and would thus have significance outside the Faeroe Islands also. 


\section{Volcanic evolution}

The volcanic history of the Faeroe Islands can probably be summarized in the following way: The volcanic activity started in the west, near the crest of the Wyville-Thompson Ridge, with aphyric, quartz tholeiitic lavas. Later it moved eastwards and for a prolonged period it was located on the eastern flank of the ridge, i.e. almost in the middle of the present group of islands, where it produced porphyritic quartz tholeiitic lavas. Finally it moved east again, away from the ridge, and produced the undifferentiated, olivine tholeiitic lavas, which are transgressive from the east.

The volcanic activity was evidently diminishing during the production of the upper lavas, since the individual flows in this series are only about half as thick as the flows which constitute the lower lava series.

When the plateau had been formed the three basalt series lay, one upon the other, separated by weak unconformities. The upper lavas must have been horizontal when the dykes, irregular intrusive bodies and sills were emplaced.

Evidently the oceanic ridge to the west continued to rise, although only very gently, until finally the upper lava series had acquired its present weak easterly dip.

The bulk composition of that part of the Faeroese plateau which is above sea level at present is as follows:

Aphyric, quartz tholeiitic lavas $\ldots \ldots \ldots \ldots \ldots$
Porphyritic, quartz tholeiitic lavas $\ldots \ldots \ldots \ldots$
Olivine tholeiitic lavas $\ldots \ldots \ldots \ldots \ldots \ldots$

The petrogenetic evolution of the Faeroe Islands can be explained very simply in terms of an old oceanic ridge in which the thermal front rose locally and later retreated. Tholeiitic basalts are predominant. 


\section{Geophysical measurements}

In the course of the last 10 years various geophysical investigations have been undertaken in the Faeroe Islands; these have used as a basis a preliminary structural map and the main geological profile that we established during the mapping work (see Noe-Nygaard and Rasmussen 1968).

Since the geophysical work has of course significance for the geological interpretation presented in the foregoing pages we can refer briefly to some of the most important results.

Abrahamsen and Saxov have published a gravity map, which in a somewhat revised form was republished two years later (1964, 1966). The main features of the map agree well with the structural map (Noe-Nygaard 1966).

Abrahamsen (1967) has shown by simple compass measurements that there are three successive zones, one above the other, with different magnetization in the lower basalt series of Suðuroy; at the bottom is a zone with normal magnetization, which is overlain by one with reverse magnetization; this in turn is overlain by a zone with normal magnetization. Above the coal-bearing sequence the direction of magnetization changes again, and this direction of magnetization appears to prevail the whole way through the middle and upper basalt series. On the basis of the magnetic data it would seem that the lower basalt series has had a longer time of formation than the two series above, but at any rate there is a sudden change after the deposition of the coal-bearing beds.

Magnetic work commenced some time ago is being continued by D. H. Tarling in Newcastle-upon-Tyne (Tarling and Gale 1968).

G. Pálmason (1965) has made two refraction profiles in the Faeroe Islands and discovered three seismically different layers: a top layer with a $P$ velocity of $3.9 \mathrm{~km} / \mathrm{sec}$., comprising our upper basalt series, a middle layer with a $P$ velocity of $4.9 \mathrm{~km} / \mathrm{sec}$., comprising our middle and lower basalt series, and finally below this a lower layer with a $P$ velocity of $6.4 \mathrm{~km} / \mathrm{sec}$. It thus appears that the Faeroese plateau, which consists entirely of basaltic lavas gives two 
different $P$ values; the composition of the third and lowest layer is unknown.

It is of significance for the threefold division of the plateau basalt series of the Faeroe Islands that we have made on a purely geological basis to note that the magnetic measurements show a difference between the lower basalt series and the two series above, while the seismic results show a difference between the upper basalt series and the two series below. The two completely different geophysical techniques together reveal a threefold division of the plateau and individually show the position of the A- and C-horizons; they thus corroborate the results we achieved by geological mapping. 


\section{Economic geology}

The Faeroese plateau basalts are poor in minerals and rocks of any particular economic importance. The materials that have been exploited from time to time will be mentioned below.

Basalt. In earlier times basalt was used on a large scale as a building material (boulders) in building walls round fields and pasture land, outhouses and to some extent dwelling houses.

In recent times it has been to some extent quarried and used in the building industry. A limited company A/S Føroya Mekaniski Grótídnađur produces basalt slabs for facing buildings and for tiles and other purposes, partly for home use and partly for export. However, this industry has not yet attained any great importance. Crushing of the basalt provides enough material to cover the home demand for crushed stone. The basalt for crushed stone is worked in open quarries. Basalt and basaltic products could have a much greater importance for export if freight and transport costs did not represent a considerable hindrance.

Sand. Most of the sand used in the building industry is obtained from the bottoms of fjords and bays. Moraine sand has only been used to a small extent.

Tuff. In the years before and after the war a hard, red tuff at Argisfossar in Streymoy was quarried and used in powdered form for the production of rust-preventing paint under the name "Fær $\varnothing-$ sit".

Tuffaceous clay. Tuff-clay sediments with marked properties as ion-exchangers have been used technically in water filters for softening hard water. Quarrying of tuffaceous clay for export was undertaken in the years just before the war and in the years after the war until the middle of the 1950 s, when it was rendered uncompetitive by various synthetic products designed for the same purpose. Tuffclay sediments were worked in Nólsoy (Hósmøl), at Dalur in Sandoy, on a trial scale north of Skálavík in Sandoy and in Gásadalur in Vágar.

Peat. Peat has had great importance on the home market for 
centuries as a fuel. Peat bogs occur in low areas, along valley sides and up between the mountains. Most of the bogs are spring bogs; fens are less common. The thickness of the peat is usually $1-1.5 \mathrm{~m}$. Only insignificant amounts of peat are cut today.

Coal. The Faeroese coal, as already mentioned in the section on the coal-bearing sequence, has been known and worked from time to time for local consumption, at any rate for the last 2-300 years. Sometimes it has been worked privately and sometimes by the administration.

Coal mining is still being undertaken in the northern coalfield (Prestfjall, Rókhagi), and in the southern coalfield (Rangibotnur). The mining is being undertaken privately and in a primitive form. In the years after the war it has covered an important part of the Faeroese consumption of household coal, but is now on the decline. Attempts to start an export of Faeroese coal have never been rewarded with success.

Clay. Repeated attempts have been made to use the various types of clay that occur in considerable amounts together with the coals, including fireclay, but these have not yet achieved any success.

Fuller's earth. Fuller's earth (montmorillonite) occurs in small amounts as a filling in lamellar zones in gjógvs, especially in the south-eastern part of Vágar towards Vestmannasund and in Hósteinsgjógv in Nólsoy. It is still uncertain whether it will be possible to use it to advantage.

Diatomaceous earth. Diatomaceous earth occurs sometimes in quite insignificant amounts below the peat bogs. It has been used occasionally for local purposes.

Semiprecious stones. Varieties of quartz such as rock crystal, chalcedony, agate, onyx, cornelian, jasper and opal occur commonly. They have never really been worked on an economic scale, but in earlier times were collector's items for Faeroese and other collectors.

Metals. The occurrences of copper and iron ore are so insignificant that it is unlikely that they will ever have any practical significance. 


\section{References}

(Important unpublished works are given in brackets.)

Abrahamsen, N. 1967: Some paleomagnetic investigations in the Faroe Islands. - Meddr. dansk geol. Foren. 17, 371-384.

Allan, T. 1813: An Account of the Mineralogy of the Faroe Islands. - Trans. R. Soc. Edinb. 7, 229-267.

Bergh, L. 1905: Bjergværksdrift. In De Danske Atlanterhavsøer. Afsnit 2, 292-296. København.

Born, (C. L. U.) v., Capitain, 1792: Om Basalt-Bierge paa Færøerne. Udtog af Brev fra Hr. Capitain Born til Hr. Etatsraad Rothe. - Skr. Naturh.Selsk. København, 2, 198-204.

Born, (C. L. U.) v., Capitain, 1793: Fortsættelse af Brevvexlingen imellem Hr. Capit. Born og Hr. Etatsraad Rothe, om de Færøske Basalt-Bierge. Skr. Naturh.-Selsk. København, 3, 123-144.

Born, (C. L. U.) v., Capitain, 1797: Fortsættelse af Brevvexlingen fra Capitain Born til T. Rothe, om den Færøiske Basalt. - Skr. Naturh.-Selsk. København, 4, 20-37.

Bøggild, O. B. 1918: Den vulkanske Aske i Moleret. - Danm. geol. Unders. række 2, 33.

Bøggild, O. B. 1922: Geologiske Forhold. In Danmark Land og Folk. Færøerne, 9-15, København.

Bøggild, O. B. 1928: Færøerne. Oversigt over Danmarks Geologi. - Danm. geol. Unders. række 5, 4, 166-169.

Forchhammer, J. G. 1824: Om Færøernes geognostiske Beskaffenhed. - Vid. Selsk. Skr., København, 159-206.

Forchhammer, J. G. 1927: Rejse til Færøerne. - Dagbog 1821. 1, 83 pp \& 2, 49 pp. Ad. Clément. København.

Geikie, A. 1896: The Tertiary Basalt-plateaux of North-western Europe. Q. Jl. geol. Soc. Lond. 52, 331-406.

Geikie, J. 1880: On the Geology of the Færöe Islands. - Trans R. Soc. Edinb. 30, 217-269.

Hartz, N. 1903: Planteforsteninger fra Færøerne. - Meddr. dansk geol. Foren. 9, 61-66.

Helland, A. 1880: Om Færøernes Geologi. - Geogr. Tidsskr. 4, 149-179.

(Henchel, O. 1778-1779: Underdanigst Beretning om det Arbejde og de Iagttagelser, som bleve gjorde under min Nærværelse på Færøerne i Aarene 1778-1779.)

Humlum, J. 1943: Mineralproduktionen paa Færøerne. In Humlum, J.: Danmarks Minedrift, 179-186. København. 
Johnstrup, F. 1873: Om Kullagene paa Færøerne, samt Analyser af de i Danmark og de nordlige Bilande forekommende Kul. - Overs. $K$. danske Vidensk. Selsk. Forh., 147-188.

Kabell, F. C. 1851: Beskrivelse af de efterhaanden foretagne Undersøgelser af Steenkullene paa Færøerne, deres Drift og Betingelserne for sammes heldige Fremgang. - Reprinted in: Forslag og Betænkninger afgivne af Den Færøske Landbokommission. København 1911, 783-796.

Laufeld, O. 1965: Sporomorphs in Tertiary coal from the Faeroe Islands. Geol. För. Stockh. Förh. 87, 231-238.

Landt, J. 1800: Forsøg til en Beskrivelse over Færøerne, 4-21, 92-105 \& 161-175. København.

Les Gisements de Houille de Suderö (Iles Feroë) 1908. 85 pp. Paris.

Lomas, J. 1895: Geology of the Faroe Islands. - Proc. Lpool. geol. Soc. 1894-95, 292-313.

Mackenzie, Sir G. S. 1814: An Account of some Geological Facts Observed in the Faroe Islands. - Trans. R. Soc. Edinb. 7, 213-227.

(Marstrander, H. 1950: Report on the coal position on the Faroe Islands. København.)

Nielsen, H. 1933: Danmark og Kullene paa Færøerne. - Tilskueren $\star$, København, 50, 376-388.

Noe-Nygaard, A. 1939: Sideromelantuf fra Færøerne. - Meddr. dansk geol. Foren. 9, 422-425.

Noe-Nygaard, A. 1940: Om Gjógv-Systemernes Alder paa Færøerne. Meddr. dansk geol. Foren. 9, 542-547.

Noe-Nygaard, A. 1940: Planteførende Tuffer fra Færøerne. - Meddr. dansk geol. Foren. 9, 548-549.

Noe-Nygaard, A. 1945: Nogle tektoniske iagttagelser fra Færøerne. - Meddr. dansk geol. Foren. 10, 541-545.

Noe-Nygaard, A. 1945: Om intrusionsforholdet hos nogle færøske Gange. Meddr. dansk geol. Foren. 10, 546-547.

Noe-Nygaard, A. 1966: The invisible part of the Faroes. - Meddr. dansk geol. Foren. 16, 191-195.

Noe-Nygaard, A. 1967: Dredged basalt from Skagerak. - Meddr. dansk geol. Foren. 17, 285-287.

Noe-Nygaard, A. \& Rasmussen, J. 1968: Petrology of a 3000 metre sequence of basaltic lavas in the Faeroe Islands. - Lithos, 1. Oslo, 286-304.

Pálmason, G. 1965: Seismic refraction measurements of the basalt lavas of the Faeroe Islands. - Tectonophysics, 2, 475-482.

Peacock, M. A. 1927-28: Recent Lines of Fracture in the Færoes, in Relation to the Theories of Fiord Formation in Northern Basaltic Plateaux. Trans geol. Soc. Glasg. 18, 1-26.

Rasmussen, J. 1946: Oversigt over den geologiske litteratur vedrørende Færøerne. - Meddr. dansk geol. Foren. 11, 66-96.

Rasmussen, J. 1947: Nyere iagttagelser over laghældningen og de kulførende dannelser paa Mykines (Færøerne). - Meddr. dansk geol. Foren. 11, 179-188.

Rasmussen, J. 1951: Transgressive sillintrusioner i Færøplateauet. - Meddr. dansk geol. Foren. 12, 164 pp. 
Rasmussen, J. 1951: Nyere synspunkter vedrørende de færøske kullags stratigrafi. - Meddr. dansk geol. Foren. 12, 164 s.

Rasmussen, J. 1952: Um Kolarannsóknir i Hvalba. - Fróđskaparrit, 1, 131-147.

Rasmussen, J. 1952: Bidrag til forståelse af den færøske lagseries opbygning. - Meddr. dansk geol. Foren. 12, 275-283.

Rasmussen, J. 1955: Nøkur orð̋ um gjáir í Føroyum uppruna teirra og aldur. - Fróoskaparrit, 4, 108-124.

Rasmussen, J. 1957: Yvirlit yvir innskotin grótsløg í Føroyum. - Fróðskaparrit, 6, 61-96.

Rasmussen, J. 1958: Kolanøgdin í Suðuroy. - Fróðskaparrit, 7, 102-144.

Rasmussen, J. 1959: De færøske kulforekomster og deres kortlægning. Meddr. dansk geol. Foren. 14, 184-188.

Rasmussen, J. 1962: Um goshálsar í Føroyum. - Fróơskaparrit, 11, 81-94.

Rasmussen, J. \& Koch, B. Eske 1963: Fossil Metasequoia from Mikines, Faroe Islands. - Fróoskaparrit, 12, 83-96.

Rasmussen, J. \& Noe-Nygaard, A. 1966: New data on the geological age of the Faeroes. - Nature, Lond. 209, 1229-1230.

Rasmussen, J. \& Noe-Nygaard, A. 1969: Beskrivelse til Geologisk Kort over Færøerne. - Danm. geol. Unders. række 1, 24.

Rasmussen, R. 1925: Um skógir í Føroyum í forðum. - Varđin, Tórshavn, 5, 153-163.

Rudolphi, Hans 1913: Die Färöer. - Z. Ges. Erdk. Berl. 57 pp.

Saxov, S. \& Abrahamsen, N. 1964: A note on some gravity and density measuring in the Faroe Islands. - Boll. di geofis Teor. ed Appl. 4, 249-260.

Saxov, S. \& Abrahamsen, N. 1966: Some geophysical investigations in the Faroe Islands. - Z. Geophys. Sonderh., 32, 455-471.

Simpson, J. B. 1928: Notes on the Geology of the Faroe Islands. - Geol. Mag. 65, 510-517.

Stokes, H. A. 1874: Notes upon the Coal Seam and Geology of Suderöe. Trans. Chester. Derby. Inst. Engrs. Lond. 2.

Tarling, D. H. \& Gale, N. H. 1968: Isotopic dating and palaeomagnetic polarity in the Faroe Islands. - Nature, Lond. 218, 1043-1044.

Trevelyan, W. C. 1823: On the Mineralogy of the Faroe Islands. - Trans. Soc. Edinb. 9, 461-464.

Ussing, N. V. 1902: Mineralproduktionen i Danmark ved Aaret 1900. Danm. geol. Unders. række 2, 12, 91-94.

Walker, F. and Davidson, C. F. 1936: A Contribution to the Geology of the Faeroes. - Trans. R. Soc. Edinb. 58, 869-897. 


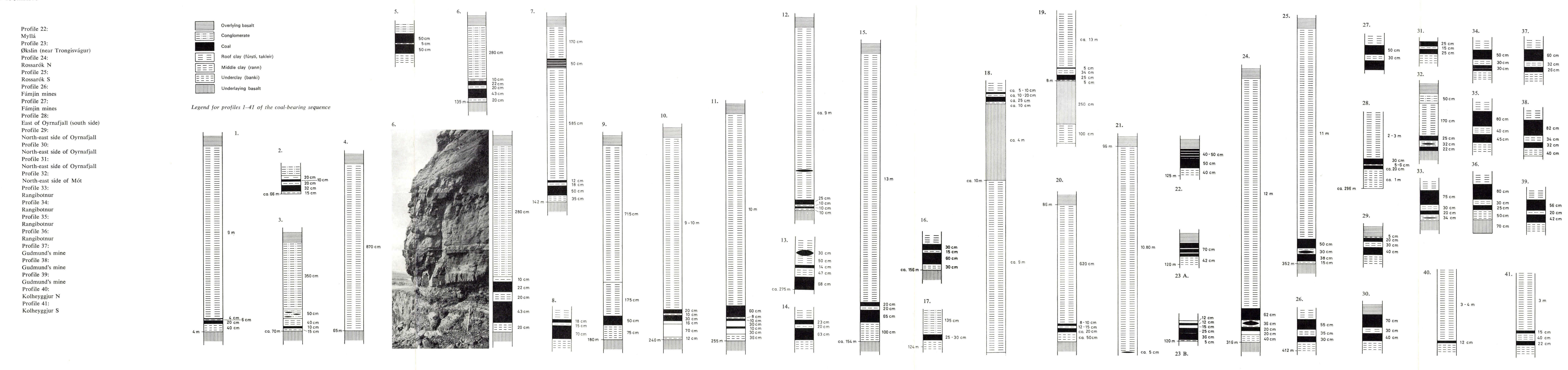



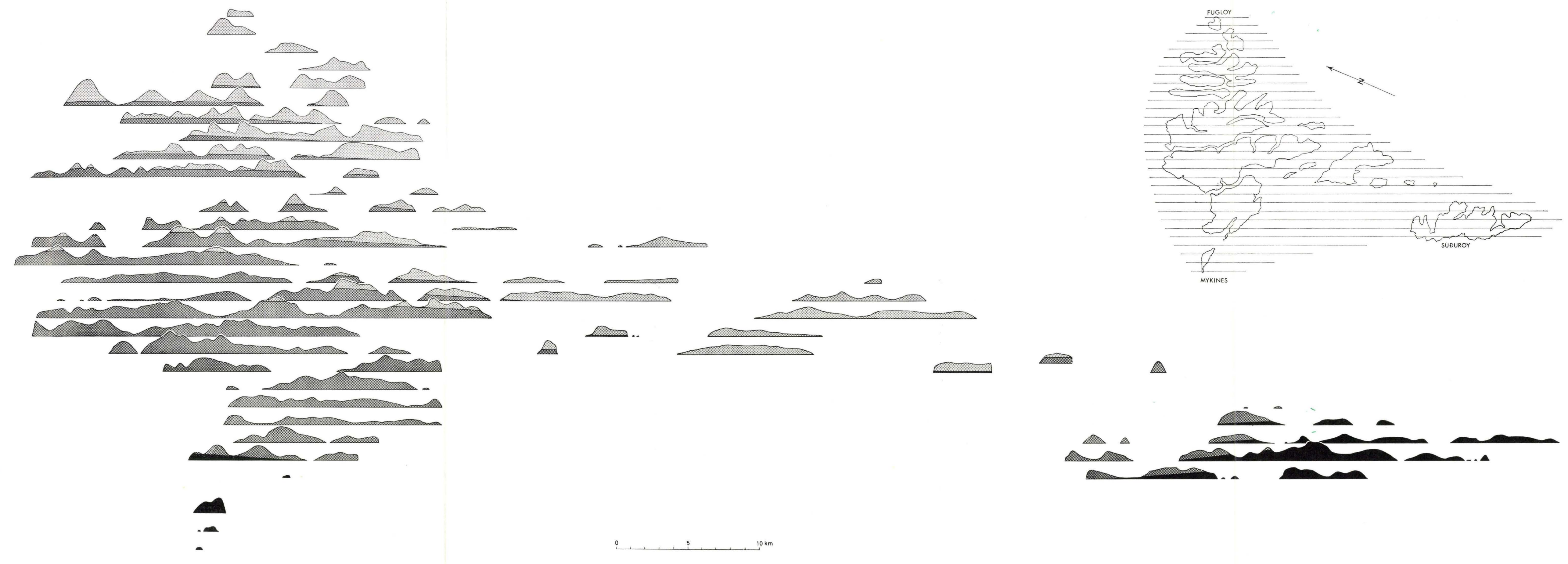


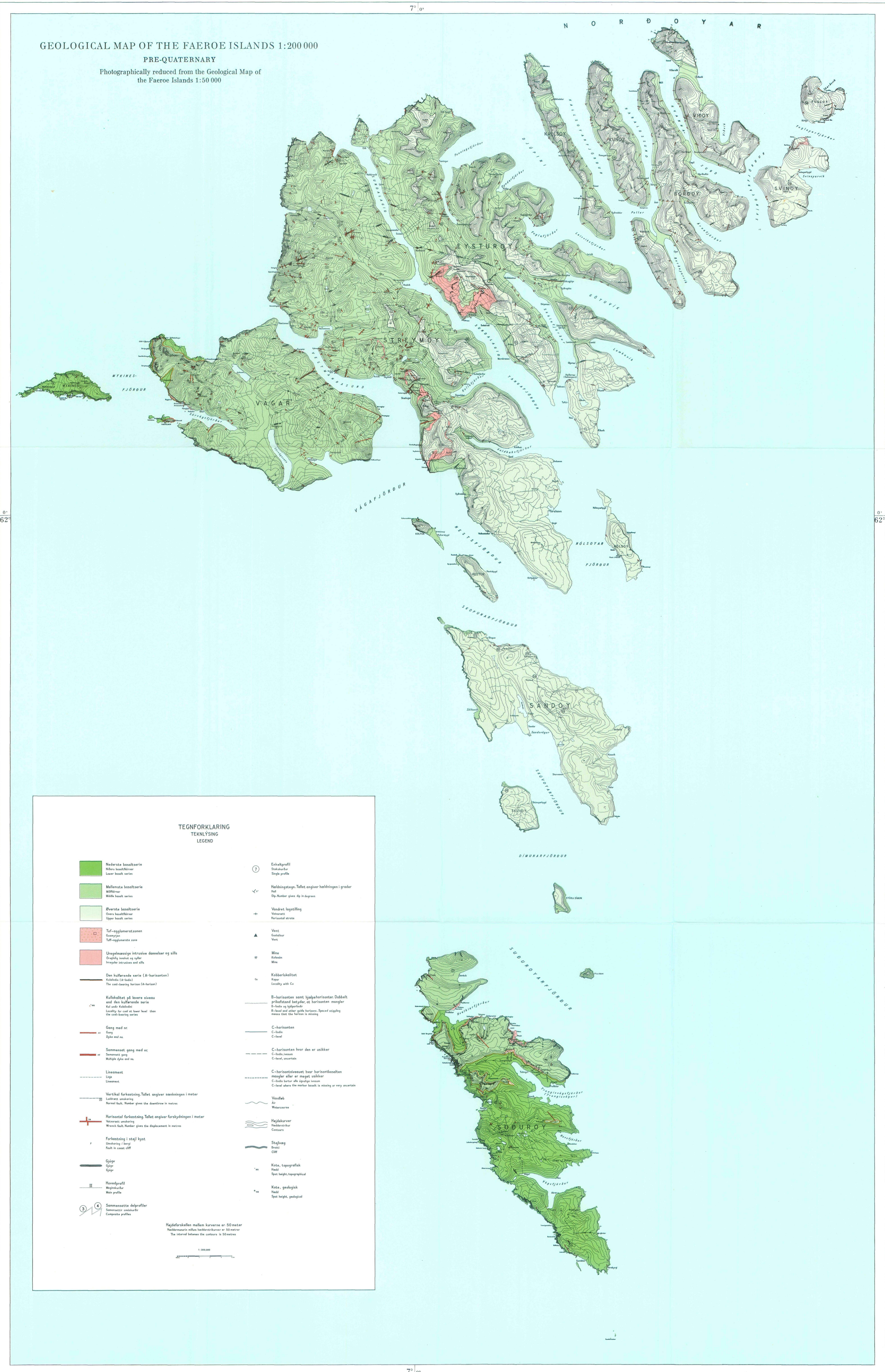

